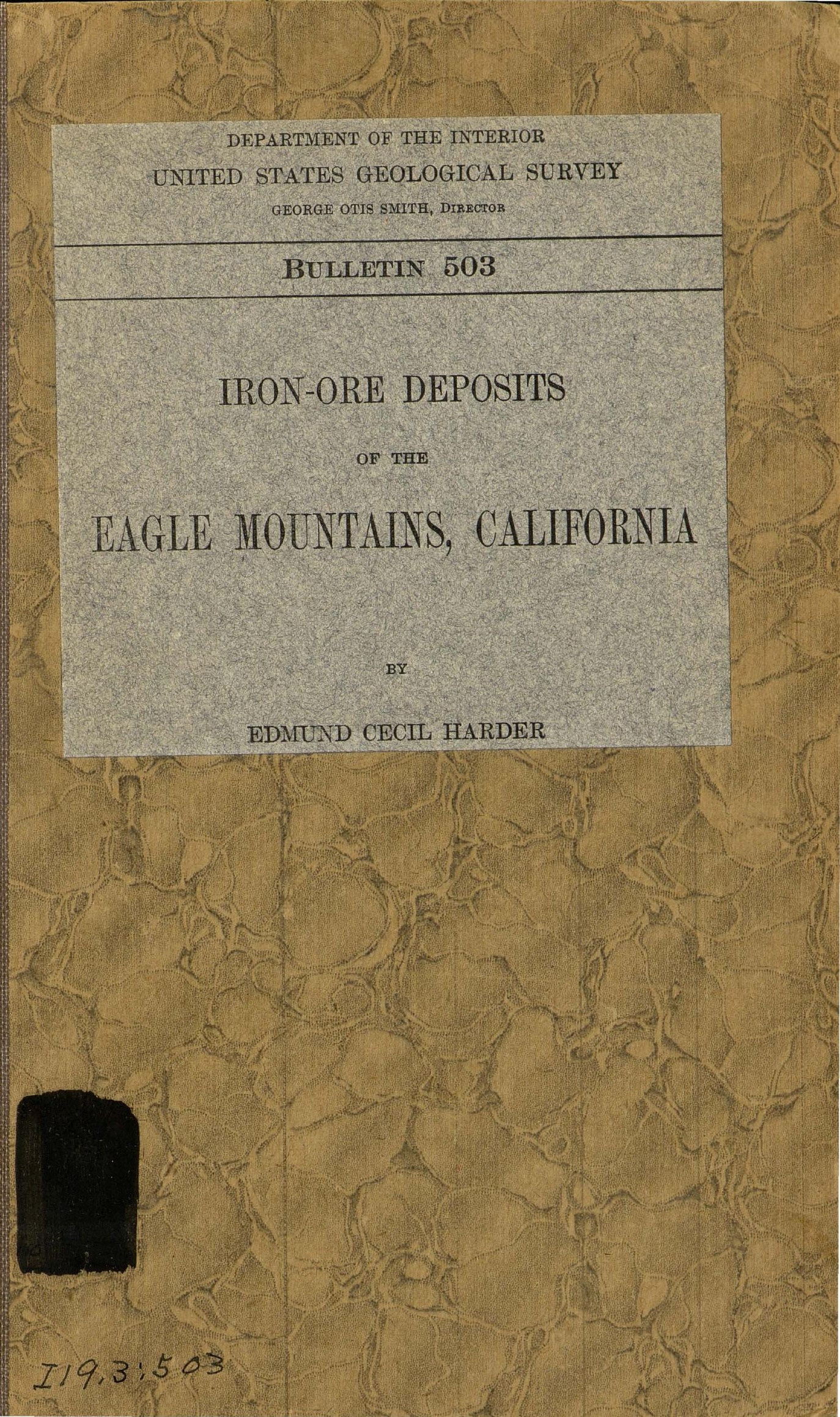


TEXAS TECH UNIVERSITY

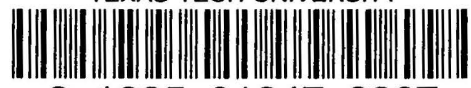

3 1295013472807 
DEPARTMENT OF THE INTERIOR

UNITED STATES GEOLOGICAL SURVEY

GEORGE OTIS SMITH, DIRECTOR

BULLETIN 503

\section{IRON-ORE DEPOSITS}

OF THE

\section{EAGLE MOUNTAINS, CALIFORNIA}

BY

EDMUND CECIL HARDER

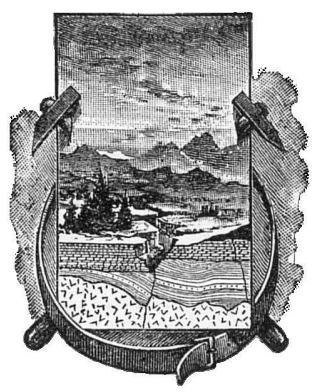

WASHINGTON

GOVERNMENT PRINTING OFFIOE 



\section{CONTENTS.}

Introduction Page.

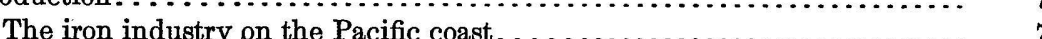

Literature.

Scope of the work. . . . . . . . . . . .

Acknowledgements. . . . . . . . . . . . . . . . . . . . 10

Geography and topography $\ldots \ldots \ldots \ldots \ldots \ldots \ldots \ldots \ldots \ldots \ldots \ldots \ldots \ldots \ldots \ldots$

Location of the district. ............................... 10

Topography, vegetation, and climate..................... 12

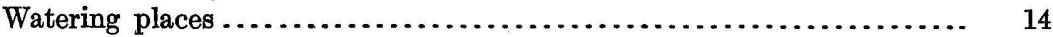

Cottonwood springs. . . . . . . . . . . . .

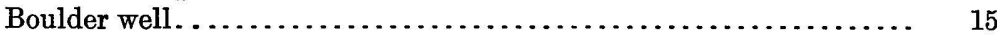

Placer Canyon reservoir. . . . . . . . . . . . . . 15

Eagle tank. . . . . . . . . . . . . . . . . . . 15

Other watering places. . . . . . . . 16

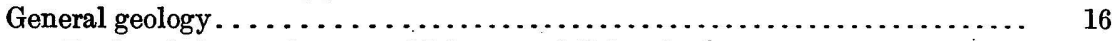

Rocks of the southeastern Mohave and Colorado deserts . . . . . . . . . . 16

Previous work. . . . . . . . . . 16

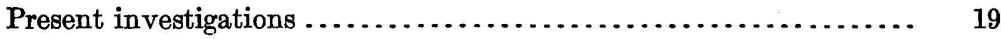

General succession of deposits. . . . . . . . . . . . . 19

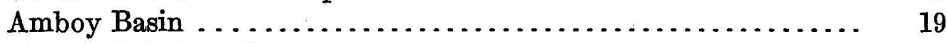

Sheephole Mountains. . . . . . . . . . . . . . . . . . . . 20

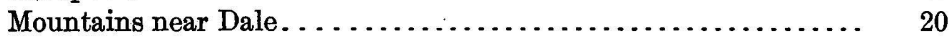

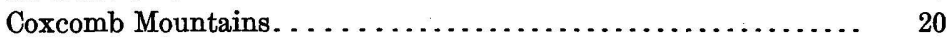

Palen Mountains................................... 20

Maria Mountains. . . . . . . . . . . . . . . . . . . . . . . 20

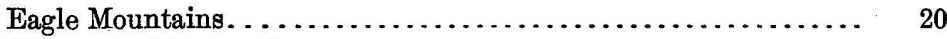

Cottonwood Mountains............................ 21

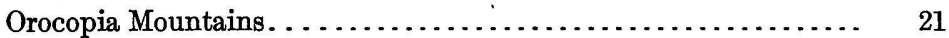

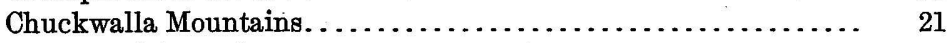

Chocolate Mountains........................... 21

Physiographic history of the desert region . . . . . . . . . . . . . . . 21

General geology of the Eagle Mountain iron-ore area............. 22

Rock formations and structure . . . . . . . . . . . . . . . . . 22

Iron-ore deposits. . . . . . . . . . . . .

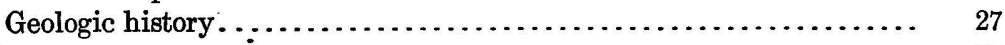

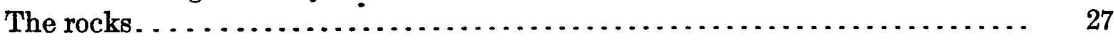

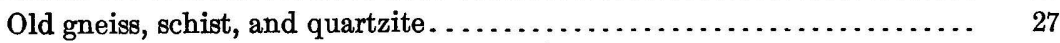

Distribution and structure of the gneiss. . . . . . . . . . . . . . 27

Petrography of the gneiss. . . . . . . . . . . . . . . . .

Schist and quartzite . . . . . . . . . . . . . . . . . . . . . . . . . $\quad 29$

Sedimentary rocks. . . . . . . . . . . . .

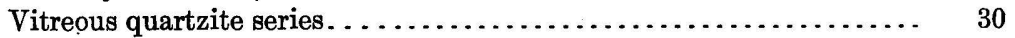

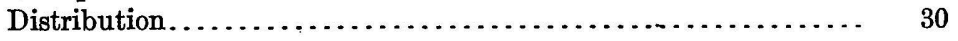

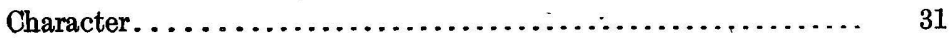


The rocks-Continued.

Sedimentary rocks-Continued. Page.

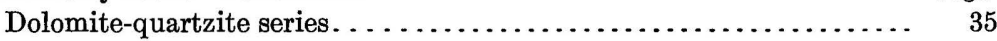

Distribution........................................ $\quad 35$

Character. . . . . . . . . .

Later fluviatile deposits. ............................... 41

Igneous rocks............................................... 42

General distribution and character........................ 42

Intrusive quartz monzonite............................. 42

Distribution and structure. . . . . . . . . . . . . 42

Petrography.................................... 44

Feldspathic phase of quartz monzonite................. 47

Epidotic phase of quartz monzonite.................. 48

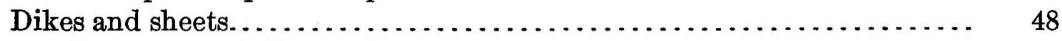

Character and distribution............................... 48

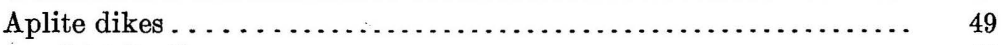

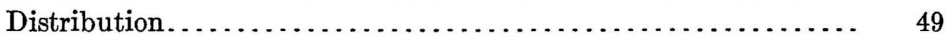

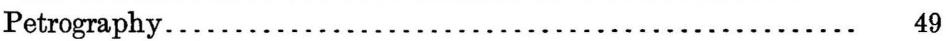

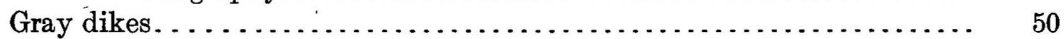

Quartz-hornblende diorite............................. 50

Distribution......................................... 50

Petrography....................................... 50

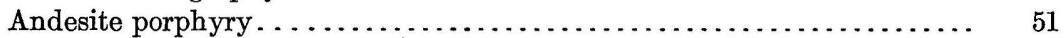

Distribution........................................... 51

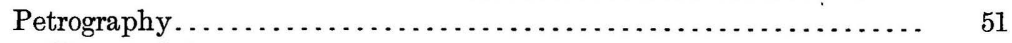

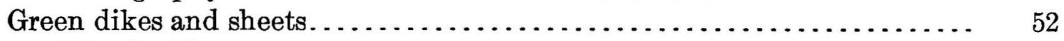

Distribution........................................... 52

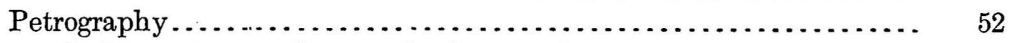

Soda syenite porphyry and microsyenite $\ldots \ldots \ldots \ldots \ldots \ldots \ldots . \quad 52$

Microdiorite..................................... 53

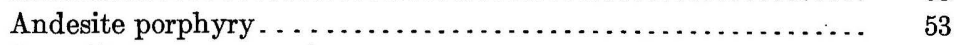

Scapolite-pyroxene rock . . . . . . . . . . . 53

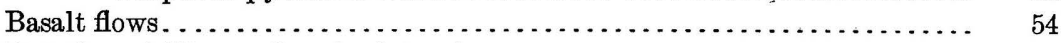

Relation of dikes and major intrusions......................... 55

The ore deposits............................................. 55

Distribution of the deposits............................... 55

Geologic relations and structure of the deposits................... 59

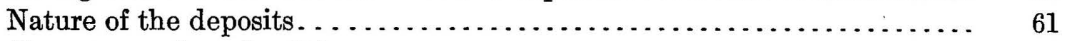

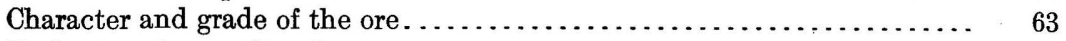

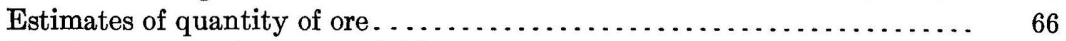

Developments and commercial importance..................... 68

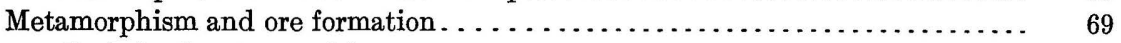

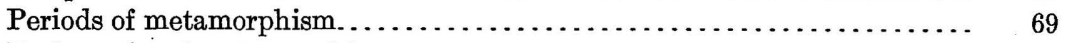

Early regional metamorphism................................. 70

Metamorphism by quartz monzonite........................ 70

Metamorphism by ore-bearing solutions........................ 73

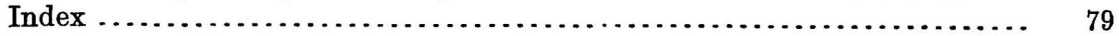




\section{ILLUSTRATIONS.}

Plate I. General geologic and topographic map and sections of the Eagle

Page. Mountain iron-ore district....................... In pocket.

II. $A$, Northern part of Coxcomb Mountains, looking northeast from western part of the iron-ore district; $B$, Mountains near Dale, looking north from western part of the iron-ore district..............

III. $A$, Cottonwood Springs, about 20 miles southwest of the iron-ore district; $B$, Iron Chief mine, looking south.....................

IV. Map and sections showing distribution and structure of iron ore and associated rocks in the east end group of ore deposits ........ In pocket.

V. Map and sections showing distribution and structure of iron ore and associated rocks on Iron No. 26, Iron No. 27, Black Diamond No. 8, and Black Diamond No. 45 claims......................

VI. Map and section showing distribution and structure of iron ore and associated rocks on Iron No. 30, Black Diamond No. 1, and neighboring claims..................................

VII. Map showing complexity of distribution of iron ore and various phases of contact rock along the contact of quartz monzonite and dolomite-quartzite series, two-thirds of a mile northeast of the Iron Chief mine........................................

VIII. Map showing distribution of iron-ore deposits on mining claims in the Eagle Mountain district...................... In pocket.

IX. $A$, Iron-ore deposits on Rodger No. 8, Rodger No. 9, Virginia, and Wizard claims, looking west; $B$, Iron-ore deposits on Virginia, Katie Gray, Rodger No. 8, Patagonia No. 5, Rodger No. 4, and Rodger No.

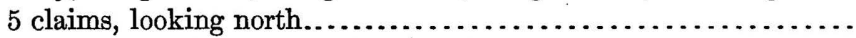

X. $A$, Iron-ore belt looking west from Katie Gray claim toward the summit of the range; $B$, Iron-ore deposits on Rodger No. 1, Rodger No. 2 , Iron No. 1, Iron No. 2, and Iron No. 5 claims................

XI. $A$, Iron-ore deposit on Iron No. 26 claim, looking west; $B$, Iron-ore deposit on Iron No. 27 claim, looking east. .................

XII. $A$, Iron-ore deposits on Iron No. 30, Black Diamond No. 1, and neighboring claims, looking north across Placer Canyon; $B$, Iron-ore deposit on Iron No. 27 claim, looking west across ravine. . . . . . .

XIII. $A$, Mixed iron ore and crystalline dolomite, showing structure of ore in detail; $B$, View from ridge of contact rock about two-thirds of a mile north of Iron Chief mine, looking east................

Figure 1. Map of parts of southern California, Nevada, and Arizona, showing location of the Eagle Mountain iron-ore district with reference to other iron-ore districts of the Mohave and Colorado deserts........

2. Generalized section of the rocks of the Eagle Mountain iron-ore district.............................................

3. Sketch map of the Eagle Mountain dome...................

4. Diagram showing iron and phosphorus content of Eagle Mountain iron ores.......................................... 



\title{
IRON-ORE DEPOSITS OF THE EAGLE MOUNTAINS, CALIFORNIA.
}

\author{
By Edmund Ceorl Harder.
}

\section{INTRODUCTION.}

\section{THE IRON INDUSTRY ON THE PACIFIC COAST.}

The iron ores of the Pacific coast have received but little attention until recent years. Numerous deposits have been known to exist, but they have generally been considered too far from centers of consumption and fuel supplies to be worked at a profit and too small to warrant the expense of erecting furnaces within reach.

At present there are four furnaces on the Pacific coast-two charcoal furnaces (one at Port Townsend, Wash., and one at Oswego, Oreg.) and two electric furnaces (one at Hood River, Oreg., and one near Baird, Cal.). The Irondale furnace at Port Townsend, consisting of one stack, was erected in 1880-81 and has been active intermittently since that time. The ores used have been obtained from Texada and Vancouver islands, British Columbia, and from a few localities in western Washington. The fuel used is charcoal, which is obtained from forests in the vicinity. At present a great impetus is being given to the iron industry in Washington by the erection of a modern steel plant at Port Townsend. The furnace at Oswego, erected in 1888 and inactive since 1894, obtained its ores and fuel from the vicinity of that place. The electric furnace at Hood River has not yet reached the commercial stage. It was built in 1907 for the purpose of experimenting on the manufacture of pig iron from black sand. The Heroult electric furnace near Baird, Shasta County, Cal., was erected in 1907 by the Noble Electric Steel Co. to conduct experiments in smelting the magnetic iron ores on Pit River. The tests were successful, and in 1908 a commercial furnace was started and was completed during the fall of 1909 . It is expected that the output of this furnace will be from 15 to 20 tons of pig iron a day. The pig iron produced is said to be of excellent grade. Some years ago a small plant was started near Auburn, Placer County, Cal., to smelt the iron ores from a little deposit in the vicinity, known as 
the Hotaling deposit, but it was unsuccessful. No iron ore has been mined in California for producing pig iron, except near Baird and Auburn, though small quantities have been mined here and there for use as flux in smelting other ores.

The principal iron-ore deposits of the Pacific coast are those on Clealum River, Kittitas County, Wash.; in Skagit Valley, Skagit County, Wash.; on Pit River near Redding, Shasta County, Cal.; in Gold Valley, Sierra County, Cal.; at Minaret, Madera County, Cal.; at Iron Mountain, Cave Canyon, Providence Mountain, and Newberry, San Bernardino County, Cal.; and at Eagle Mountain, Riverside County, Cal. Of minor importance are the Northport and Valley deposits, Stevens County, Wash.; the Trafton deposit, Snohomish County, Wash.; the Snoqualmie Pass deposits, King County, Wash.; the Oswego deposit, Washington County, Oreg.; the Patamocas or Beegum deposits, Tehama County, Cal.; the Newtown and Indian Springs deposits, Nevada County, Cal.; the Hotaling deposit, Placer County, Cal.; the Detert deposit, Calaveras County, Cal.; Mount Raymond deposits, Madera County, Cal.; the Perfumo Canyon deposit, San Luis Obispo County, Cal.; and the Owl Holes, Kingston Range, Garlic Springs, and Iron Age deposits, San Bernardino County, Cal.

The Minaret deposits consist largely of magnetite and are said to be among the largest iron-ore deposits in California and perhaps in the West. They occur on the summits of the Sierra Nevada. Probably next in size, but of greater commercial importance, are the Eagle Mountain deposits, which consist largely of hematite occurring as replacements in limestone, by hydrothermal metamorphism. The Clealum iron ores are chromiferous. The deposits are scattered over a considerable area, but most of them are small. The Beegum deposits consist of low-grade titaniferous iron ore, but are reported to be very extensive. Most of the other deposits consist of magnetite or intermixed magnetite and hematite. A few consist of brown ore. Of all the deposits mentioned above only four have been mined with the intention of producing pig iron. These are the Trafton deposit in Washington, the Oswego deposit in Oregon, and the Pit River and Hotaling deposits in California, and even these have produced but little ore.

\section{IITERATURE.}

The following is a list of papers on the iron-ore deposits of the Pacific coast.

Aubury, L. E., and others. Iron. Structural and industrial materials of California, 1906, p. 287.

Diller, J. S. Iron ores of the Redding quadrangle, California: Bull. U. S. Geol. Survey No. 213, 1903, pp. 219-220.

Drller, J. S. Redding folio (No. 138), Geol. Atlas U. S., U. S. Geol. Survey, 1906. FaIrbanks, H. W. San Luis folio (No. 101), Geol. Atlas U. S., U. S. Geol. Survey, 1904. 
HARDER, E. C. Some iron ores of western and central Galifornia: Bull. U. S. Geol. Survey No. 430, 1910, pp. 219-227.

HARDER, E. C., and RrCH, J. L. The Iron Age iron-ore deposit near Dale, San Bernardino County, Cal.: Bull. U. S. Geol. Survey No. 430, 1910, pp. 228-239.

Jones, C. C. An iron-ore deposit in the California desert region: Eng. and Min. Jour., April 17, 1909.

LeItH, C. K. Iron ores of the western United States and British Columbia: Bull. U. S. Geol. Survey No. 285, 1906, pp. 194-200.

Lindgren, Waldemar. Sacramento folio (No. 5), Geol. Atlas U. S., U. S. Geol. Survey, 1894.

Lindgren, Waldemar, and Turner, H. W. Smartsville folio (No. 18), Geol. Atlas U. S., U. S. Geol. Survey, 1895.

Prescott, BasiL. The occurrence and genesis of the magnetite ores of Shasta County, Cal.: Econ. Geology, vol. 3, 1908, No. 6, p. 465.

Smith, G. O., and Willis, Bailey. The Clealum iron ores, Washington: Trans. Am. Inst. Min. Eng., vol. 30, pp. 356-366, 1901.

Turner, H. W. Jackson folio (No. 11), Geol. Atlas U. S., U. S. Geol. Survey, 1894.

Turner, H. W. Downieville folio (No. 37), Geol. Atlas U. S., U. S. Geol. Survey, 1897.

Turner, H. W., and Ransome, F. L. Big Trees folio (No. 51), Geol. Atlas U. S., U. S. Geol. Survey, 1898.

\section{SCOPE OF THE WORK.}

The examination and mapping of the Eagle Mountain and the Iron Age iron-ore deposits, ${ }^{1}$ of northern Riverside and southern San Bernardino counties, respectively, form the first detailed investigation of the iron ores of California made by the United States Geological Survey, and are a continuation of similar investigations in the Iron Springs district, in southwestern Utah, made by Dr. C. K. Leith and the writer ${ }^{2}$ several years ago. It is expected that this work will soon be continued by a detailed survey of the iron ores of central and northern San Bernardino County, and later by examinations of other iron districts of the West. Reconnaissance work has been done on other iron-ore deposits in California.

The field work in the Eagle Mountains was done during the summer of 1909, from the middle of June to the later part of September. It consisted of making a general topographic and geologic map of the iron-ore area on the scale of 1,000 feet to the inch, with a contour interval of 50 feet, and several detailed maps of the principal ironore deposits, on the scale of 250 feet to the inch, with a contour interval of 10 feet. All the mapping except that in the western part of the general area was done with a telescopic alidade, and in this work the writer was assisted by John L. Rich.

This report is designed to be principally an economic paper, treating of the structure, character, and quantity of the ores and their relation

\footnotetext{
1 Harder, E. C., and Rich, J. L., The Iron Age iron-ore deposit near Dale, San Bernardino County, Cal.: Bull. U. S. Geol. Survey No. 430, 1910, pp. 228-239.

2 Leith, C. K., and Harder, E. C., Iron ores of the Iron Springs district, southern. Utah: Bull. U. S. Geol. Survey No. 338, 1908.
} 
to the associated rocks, and including descriptions of these rocks and discussions of their relations to one another. It is not a final statement regarding the nature of the ore deposition and the various phases of contact metamorphism, though these are discussed in a general way.

\section{ACKNOWLEDGMENTS.}

The author is indebted to the persons named below for numerous courtesies extended to the party while in the field: Mr. L. S. Barnes, Mr. W. L. Holland, and Mr. W. W. Brown, of Los Angeles; Mr. R. N. Dickman and Mr. H. P. Wherry, of Chicago; and Mr. Charles E. Brown and other residents of Mecca and the adjacent country. $\mathrm{He}$ wishes especially to express his grateful appreciation to Mr. Dickman and Mr. Wherry for the several hundred chemical analyses of the iron ores and for the maps of mining claims and other information which they have furnished him. To Mr. Rich acknowledgments are due for his efficient services in the field, as well as for the proof reading of this report during the writer's absence in Brazil.

\section{GEOGRAPHY AND TOPOGRAPHY.}

\section{IOCATION OF THE DISTRICT.}

The Eagle Mountain iron ores are located in the northern part of the Eagle Mountains, northern Riverside County, Cal. (See fig. 1, p. 11, and Pl. I, in pocket.) On an air line they are 40 miles northeast of Mecca, on the Southern Pacific Railroad, 45 miles south of Cadiz, on the Atchison, Topeka \& Santa Fe Railway; and 70 miles south of west from Parker, Ariz., on Colorado River, on the Arizona \& California Railroad. The railroad last named has recently been completed to Cadiz, on the Santa $\mathrm{Fe}$, and passes about 35 miles northeast of the Eagle Mountains. The deposits extend over an area about 8 miles long and from a quarter of a mile to 2 miles wide, running across the summit of the Eagle Mountains in a general east-west direction. Direct communication between the ends of the area is established by means of several trails, over most of which one may go on horseback or may move supplies by means of pack animals. A wagon road connecting the ends runs around the southern border of the Eagle Mountains, a distance of about 65 miles. Both ends of the area are best reached by wagon from Mecca, on the Southern Pacific Railroad, which is about 50 miles distant by road from the Iron Chief gold mine, near the west end, and about 60 miles from the East End camp, at the east end. The Iron Chief mine may also be reached from Dale, San Bernardino County, by traversing a distance of about 20 miles. Dale is connected with Amboy on the Santa Fe Railway by a stage road 45 miles long, with biweekly service. The East End camp may also be reached from Parker by wagon. 
The Eagle Mountain Range is one of a large number of bare ranges of rocky mountains in the Mohave and Colorado deserts and is near the rather indefinite border between these two deserts. It is about 25 miles long in a northeast-southwest direction, and about 15 miles wide in the widest part. It is surrounded on all sides except the southwest by belts of flat deserts, beyond which lie other mountain

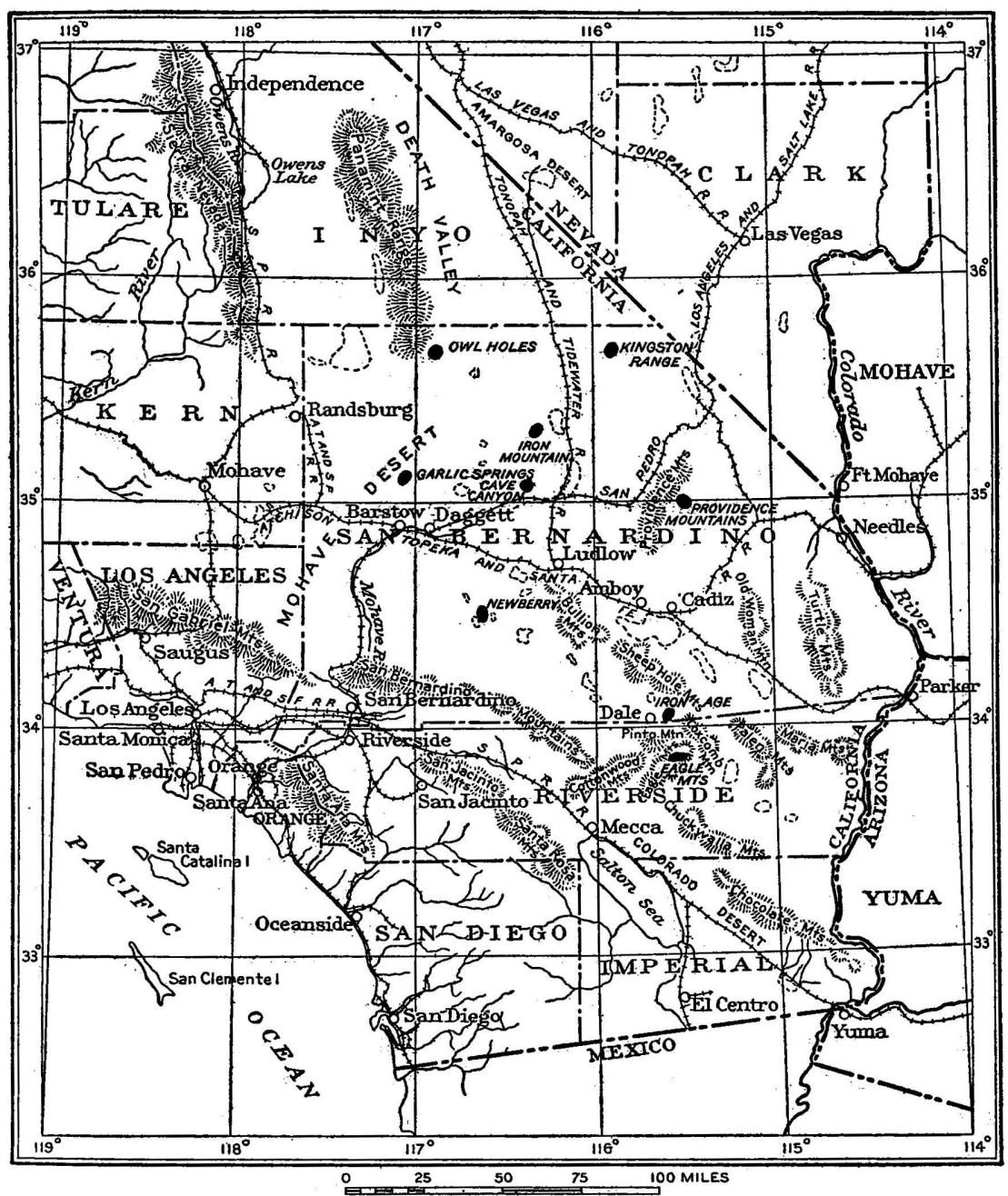

Figure 1.-Map of parts of southern California, Nevada, and Arizona, showing location of the Eagle Mountain iron-ore district with reference to other iron-ore districts of the Mohave and Colorado deserts.

ranges. To the southwest it is continuous with the Cottonwood Mountain Range, which extends westward for about 30 miles to the southeastern extension of the San Bernardino Mountains. Northwest of the Eagle Mountains, across the desert, are the Pinto Mountains and the mountains around Dale. To the northeast are the 
Coxcomb Mountains and to the southeast are the Chuckwalla Mountains. Desert belts ranging in width from a few miles to 20 miles or more separate the mountain ranges from one another, so that they appear as islands in a sea. The area in which the iron ores occur has not been surveyed by the United States Land Office and is therefore not definitely located, but will fall in about T. 3 S., R. 14 E. Meridian $116^{\circ} 30^{\prime}$ passes through the eastern end of the area and parallel $34^{\circ}$ passes about 8 miles to the north.

\section{TOPOGRAPHY, VEGETATION, AND CLIMATE.}

The topography of southeastern California is typical of the western deserts, consisting of bare mountain ranges separated by nearly flat connecting arid belts of varying width. The mountains rise abruptly from the desert, in places almost precipitously, and have the appearance of being the summits of more massive ranges whose lower slopes are submerged beneath unconsolidated desert deposits. The summits of the mountain ranges rise about 2,000 or 3,000 feet above the surrounding flat deserts, which around the border of the Eagle Mountains are about 1,500 feet above sea level. From this elevation the desert areas slope southward toward the Salton Basin, which lies about 200 feet below sea level, and eastward toward Colorado River. To the west the deserts gradually rise toward the San Bernardino Mountains; toward the north they rise for a short distance and then sink again to the Amboy Basin, which stands about 600 feet above sea level. Above this gently sloping desert protrude the mountain ranges.

Broadly speaking, the flat desert areas are tributary to each other but each separate area is in itself a local basin. Alluvial fans issue from each of the gullies in the surrounding mountains and unite into broad aprons sloping gently toward the center of the basin. (See Pl. II, A.) In the center there is commonly a flat, perfectly level area, which is in general very small compared to the desert area as a whole. This is known as a playa, dry lake, or alkali flat. Many of these flats contain water during parts of the year and most of them have a thin white crust of alkali or salt. There may be 500 or 600 feet difference of elevation between the playas and the mouths of the gullies.

The mountains are deeply dissected by a network of sharp gullies, which locally have high, precipitous walls. The slopes are bare and rocky and bear little or no débris. Within some of the mountain ranges there are traces of high gravel flats. Waterworn gravels are found at elevations of 1,500 feet or more above the alluvial aprons. Local gravel terraces also occur along the gulches, the highest at elevations 75 feet above the present beds of the arroyos. 


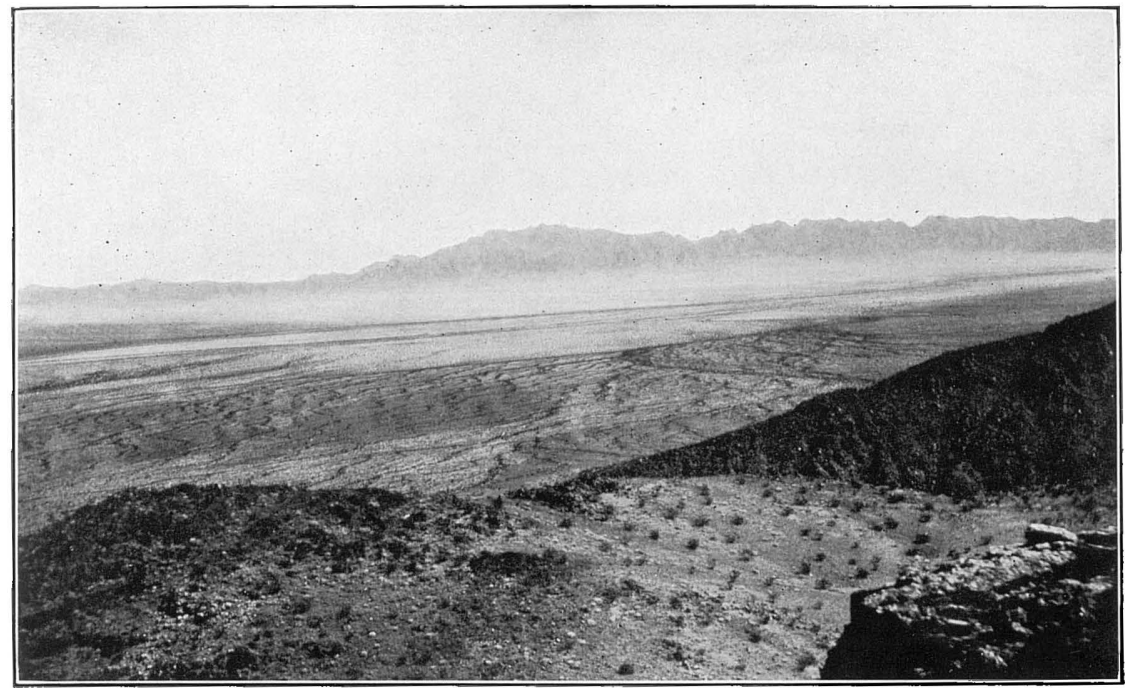

A. NORTHERN PART OF COXCOMB MOUNTAINS.

Looking northeast from western part of the iron-ore district. Shows alluvial apron sloping toward center of basin.

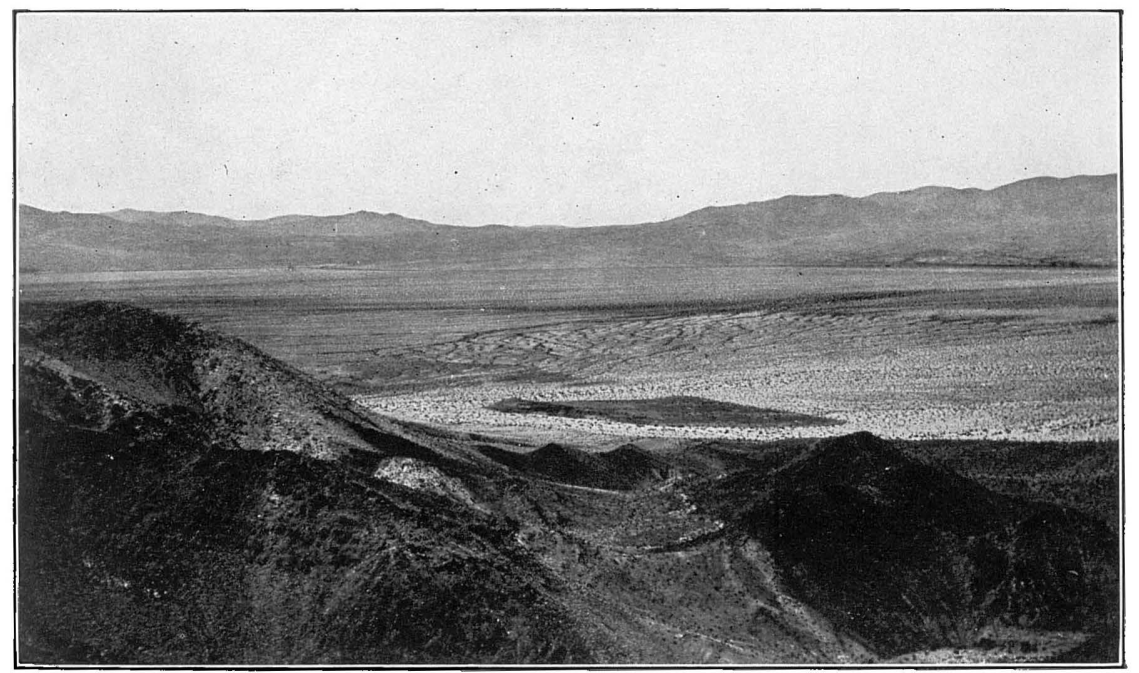

B. MOUNTAINS NEAR DALE.

Looking north from western part of the iron-ore district. 

The topography of the Eagle Mountains is not so rough as that of the neighboring ranges. Smooth, gradual slopes occur here and there in the higher parts of the range, and from a distance the entire range presents a smooth sky line of rounded summits and ridges, in great contrast to the Coxcomb Mountains to the northeast, which have a jagged saw-tooth sky line. (See Pl. II.) In all parts of the Eagle Mountains, however, there are deep, precipitous canyons, most of which unite to form broad, dry washes before reaching the edge of the mountains, although a few are gorgelike throughout their extent. The higher peaks of the Eagle Mountains rise about 4,000 feet above sea level, and the edge of the mountains or the upper part of the alluvial apron that surrounds them on the west, north, and east averages about 1,500 feet above sea level. The lowest parts of the surrounding desert valleys are about 800 to 1,200 feet above sea level. These elevations were measured with aneroid barometers, the elevation at Mecca (197 feet below sea level) being taken as the base. As the interval between the readings necessarily extended over two days, the measurements are only roughly approximate.

At several places within the Eagle Mountain Range there are broad undulating areas in which the elevations are only minor hills and ridges. Some of these areas are in places covered with thin deposits of unconsolidated gravels. Steep-walled gorges have been cut into these areas, nearly all of them in bedrock.

The principal streams draining the iron-ore area are Placer Canyon and its tributaries on the west side of the summit and a big dry wash with several large tributaries, such as Bald Eagle Gulch, on the east side. The tributaries of Placer Canyon head near the summit in the north-central part of the range, flow in minor gorges across a broad basin, and unite to form the narrow, precipitous canyon, which trends westward and breaks through the northwestern front of the mountains. For some distance from the edge of the mountains Placer Canyon has cut into the alluvial apron to depths of 20 or 30 feet. Terraces, the highest 50 feet high, occur on both sides of the canyon and its tributaries for several miles from its mouth. The big dry wash on the east side has a general east-west direction, is more than half a mile wide at its mouth, and contains several arroyos in which the torrential waters flow. (SeePl.IX, p. 58.) These arroyos are cut from a few feet to 10 feet below the general level of the wash and wind back and forth across it, issuing at its mouth at three or four different points and running in different directions down the alluvial apron, only a few feet below its general level. The dry wash is floored to an unknown depth by unconsolidated gravels and bowlders. Many canyons enter it, and in some of them, as Bald Eagle Gulch, streams have cut gorges 20 or 30 feet deep near their mouths. The 
iron ores west of the summit occur on both sides of Placer Canyon Valley; those east of the summit occur only north of the big dry wash.

The Eagle Mountains and the surrounding outwash aprons are very bare, and even desert vegetation is scarce on them. In the mountains and on the slopes the characteristic vegetation includes greasewood, ocotillo, several species of sage brush, and cacti of many varieties. The small washes in the mountains contain, in addition to these plants, cat claw, porcupine brush, and other small bushes, and in the large washes along the outwash aprons there are occasional palo verde trees and desert willows, and, rarely, ironwood. Ironwood trees become very abundant around the mountain ranges to the east and in some places cover large tracts along the outwash slopes. Gietta grass grows scatteringly along the slopes. Yuccas are rare in the Eagle Mountains, but are very abundant in the region farther west.

The Eagle Mountains and the surrounding territory typify the arid southern California desert. In summer they are hot and are exceedingly dry except at the period of torrential rains, but are cool and comfortable in the spring and fall. In winter, however, the temperature sometimes falls as low as $20^{\circ} \mathrm{F}$. Torrential rains generally fall between the middle of July and the middle of September, but during the rest of the year there is hardly a drop of rain except occasional showers in January or February. In summer the temperature goes as high as $120^{\circ} \mathrm{F}$. in the shade at times, when the heat would be almost unendurable were it not for the steady breeze during the day. The nights are generally comfortable.

\section{WATERING PLACES.}

There are only two places in the Eagle Mountain district where water can certainly be obtained-Cottonwood Springs, about 20 miles southwest of the Iron Chief mine, and Boulder well in the desert about 10 miles east of the east end of the district.

Cottonwood Springs.-Cottonwood Springs are in Cottonwood Pass in Cottonwood Mountains, 26 miles north of Mecca, on the main road to Dale. (See Pl. III.) They are 14 miles northeast of Shaver well, the only watering place between them and Mecca. The springs are readily found, their site being marked by a corral, a watering trough, and the pumping plant of the Iron Chief Mining Co. The water is of excellent quality and is usually flowing. It seeps out of granite and collects in a small concrete reservoir. Several large cottonwood trees grow near it and also mesquite brush and other water-loving plants. There are generally several men at the springs, which is a much-favored camping place.

A pipe line runs from Cottonwood Springs to the Iron Chief mine, in the Eagle Mountains, about 18 miles northward in an air line. (See 


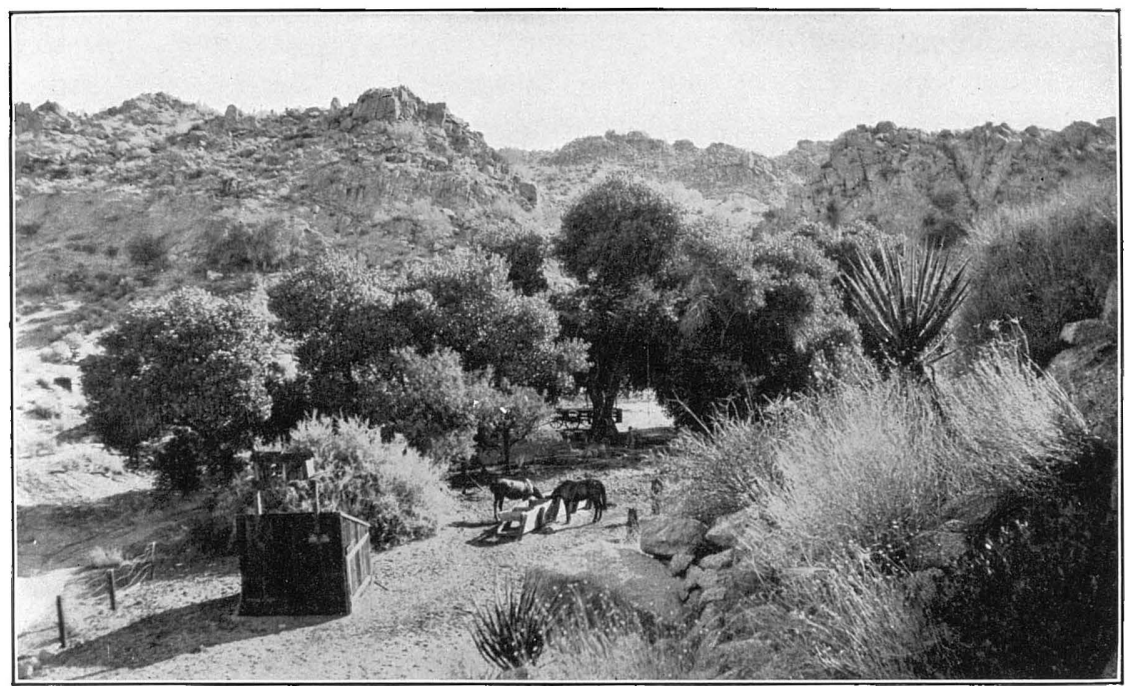

A. COTTONWOOD SPRINGS, ABOUT 20 MILES SOUTHWEST OF THE IRON-ORE DISTRICT.

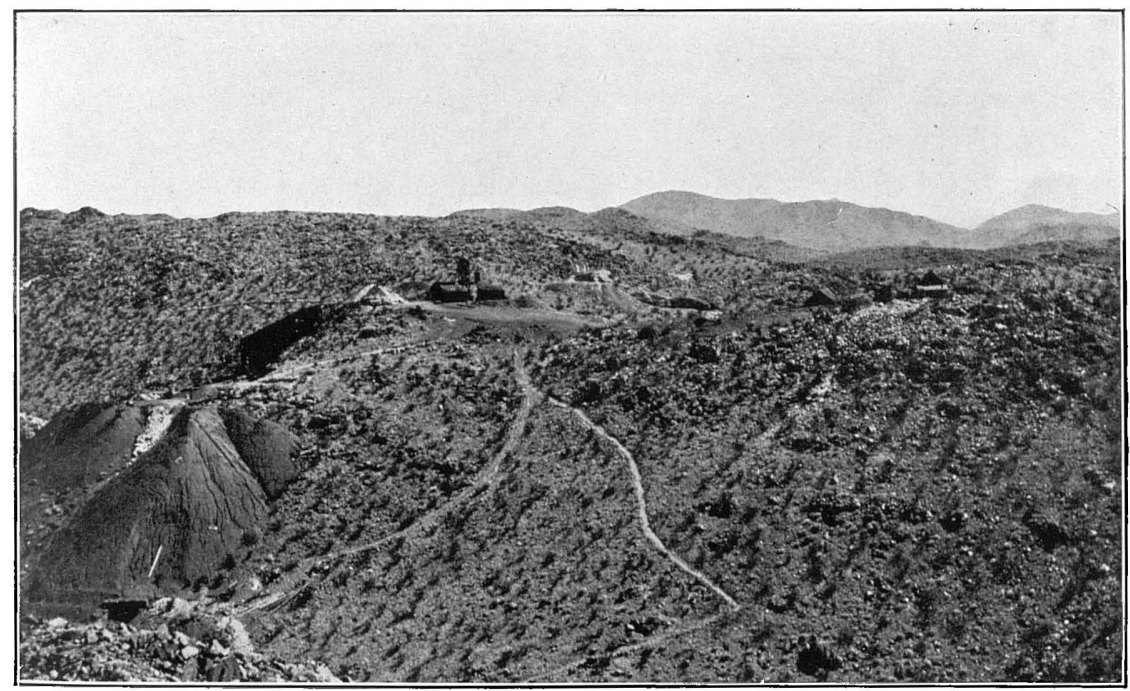

B. IRON CHIEF MINE.

Looking south. 

PI. III, B.) As the mine has been idle, the pipe line was out of order for several years, but during the fall of 1909 it was repaired, so that water can now be pumped to the mine.

Several springs are reported to occur in canyons in the southern part of the Cottonwood Mountains east of Cottonwood Springs, but they are some miles from the main road. Native palms grow at one or two of these localities.

Boulder well.-About 6 miles southwest of Palen Dry Lake a well was sunk in the middle of a broad desert area by the Granite Mining Co. The well is 80 feet deep, and there is a windmill over it which is visible for 5 or 6 miles. A new pump has recently been installed so that water may be obtained easily. Several buildings and corrals stand near the well, one of the buildings being an old mill in which gold ore from the Chuckawalla Mountains was treated. Mesquite brush grows near the well and determined the site chosen for the digging. There is generally a man living here who takes care of the well and buildings. The water is slightly alkaline, but is otherwise of good quality. No charge is made for it.

Several years ago one or two shallow wells were dug in a mesquite flat west of Palen Dry Lake, 7 or 8 miles northeast of Boulder well. The water is near the surface, but is said to be brackish and unpalatable. The wells are now filled with sand and clay and are almost obliterated, but water could probably be obtained by digging.

Placer Canyon reservoir.-A dam of cement and stone 8 or 10 feet high was built some years ago across the gorge of Placer Canyon 2 or 3 miles from its mouth, but the upper part of it was later destroyed because it obstructed the passage of pack animals up the canyon. The lower part of the dam is in gravel and is at present intact. Several natural tanks just above and below it hold water for a month or more, and the vicinity is a prominent camping place for prospectors during the wet months.

Eagle Tank.-Eagle Tank is a natural rock basin about 20 feet in diameter and 10 to 15 feet deep in the bed of a gorge tributary to Placer Canyon. The gorge is the third one entering Placer Canyon from the south below the reservoir, at a distance from it of about half a mile. The tank is several hundred yards from the mouth of the gorge and stands in its bottom at the base of a vertical cliff about 20 feet high. It is said to contain water all the year round, but during the height of the dry season the water is stale and dirty, and even during the torrential rains it is filled with green algæ and animal life, such as various crustaceans, larvæ, and tadpoles. When fresh the water is very good, and even during the dry season it is used by prospectors. for it is the only place within a radius of 15 or 20 miles where water can be procured unless the pipe line from Cottonwood springs to the Iron Chief mine is in order. 
Several other tanks occur in the Eagle Mountains in the iron-ore belt, but these hold water for only a few weeks or a month after the rains.

Other watering places.-Two springs, known as Red Ribbon Spring and Buzzard Spring, are reported as being located in the eastern part of the Eagle Mountains several miles south of the iron-ore belt. The first of these was visited during September after a month and a half of especially heavy rainfall, but no water was found and none could be obtained even by digging. Buzzard Spring was not visited.

In case of necessity water can be obtained from the Brooklyn mine, in the mountains southeast of Dale, about 10 miles north of the west end of the iron-ore district. There is no trail directly across the desert, hence water can be obtained only with pack animals. The water at the Brooklyn mine is obtained from the Dale pumping plant, 6 miles north of Dale, which also supplies Dale and the other mines in the vicinity. Water can be obtained from Dale, which is 20 miles by road from the west end of the district.

\section{GENERAL GEOLOGY.}

\section{ROCKS OF THE SOUTHEASTERN MOHAVE AND COLORADO DESERTS.}

\section{PREVIOUS WORK.}

The rocks of eastern San Bernardino and Riverside counties have received but little attention from geologists, probably because of the unfavorable climate, lack of water, difficulty of obtaining supplies, and other conditions which make life in this district disagreeable and even hazardous. Prospecting has been retarded by the same conditions, so that, perhaps, numerous mineral localities remain undiscovered even at the present time. Mining geologists and engineers have made visits to different parts of the desert region, but their examinations have generally been hasty, have covered small areas, and have necessarily been of a commercial rather than a scientific nature.

It has long been known, however, that most of the desert mountain ranges consist of old metamorphosed sediments and igneous rocks cut by later intrusives and covered locally by lava flows. The distribution of these rock types, however, was not worked out, nor was their age determined. It has generally been supposed that the old metamorphosed sediments and igneous rocks are of pre-Cambrian age, and that the later intrusives and flows are of Mesozoic and later age.

In recent years geologic work has been done in the region surrounding the southeastern Mohave and Colorado deserts, but even at present the central and southeastern parts of San Bernardino County 
and the eastern part of Riverside County remain practically unmapped geologically, and the region to the west and south is also but imperfectly known. Lee, ${ }^{1}$ Schrader, ${ }^{2}$ and Bancroft ${ }^{3}$ have mapped large areas in western Arizona and have followed the rock formations westward a short distance beyond the Colorado River in southern Nevada and southeastern California. Spurr ${ }^{4}$ and Ball ${ }^{5}$ have mapped southern Nevada and eastern California from the northern part of San Bernardino County northward, and Hess ${ }^{6}$ has examined the rocks of the Randsburg region, in western San Bernardino County. Mendenhall ${ }^{7}$ has done considerable geologic work in the San Bernardino Mountains in the southwestern part of San Bernardino County and at numerous localities in the Colorado Desert in western Riverside, northeastern San Diego, and western Imperial counties. The only significant geologic work done in the area considered in this report was that of Darton, ${ }^{8}$ who examined a small area northwest of Siam, on the Santa Fe Railway.

The rocks of western Arizona consist of granite, gneiss, schist, and various metamorphosed sediments of pre-Cambrian age intruded by granitic and dioritic rocks of Mesozoic age and overlain by Tertiary rhyolites, trachytes, and andesites, Quaternary basalt, and unconsolidated or partly consolidated desert deposits. The Paleozoic rocks of the Grand Canyon region, farther northeast, overlie the pre-Cambrian rocks and extend northward and eastward into Nevada, Utah, and northeastern Arizona. The nearest points to the Eagle Mountains at which the pre-Cambrian and later intrusive igneous rocks have been examined by Bancroft and Schrader are 55 miles directly east and 65 miles northeast, respectively. No work had been done prior to 1909 in the intervening area.

In northern San Bernardino and southern Inyo counties, according to Spurr, ${ }^{4}$ there are sediments of Cambrian, Devonian, Carboniferous, Mesozoic, and early Tertiary age, with Tertiary volcanics and earlier intrusives, as well as local pre-Cambrian schists and granite. The southernmost work of Spurr was done about 105 miles directly north of the Eagle Mountains, and the only work in the intervening area was

1 Lee, W. T., Geologic reconnaissance of a part of western Arizona: Bull. U. S. Geol. Survey No. 352, 1908. 2 Schrader, F. C., Mineral deposits of the Cerbat Range, Black Mountains, and Grand Wash Cliffs, Ariz.: Bull. U. S. Geol. Survey No. 397, 1909.

B Bancroft, Howland, Reconnaissance of the ore deposits of northern Yuma County, Ariz.: Bull. U. S. Geol. Survey No. 478, 1911.

1 Spurr, J. E., Descriptive geology of Nevada south of the fortieth parallel and adjacent portions of California: Bull. U. S. Geol. Survey No. 208, 1903.

- Ball, S. H., Geologic reconnaissance of southwestern Nevada and eastern California: Bull. U. S. Geol. Survey No. 308, 1907.

- Hess, F. L., Gold mining in the Randsburg quadrangle: Bull. U. S. Geol. Survey No. 430, 1910, pp.23-47.

7 Mendenhall, W. C., unpublished notes.

8 Darton, N. H., Discovery of Cambrian rocks in southeastern California: Jour. Geology, vol. 15, No. 5, 1907, pp. 470-475.

$19557^{\circ}-$ Bull. $503-12-2$ 
done by Darton at a point about halfway between. Darton ${ }^{1}$ found a series of metamorphosed Cambrian sediments, over 1,200 feet thick, resting on a basement of pre-Cambrian granite, 2 miles northwest of Siam. They consist largely of sandstone and quartzite, but include some shale and a few layers of limestone. Cambrian fossils were found a little above the middle of the series. The rocks form a north-south range of mountains, the Cambrian sediments dipping down the eastern slope and the pre-Cambrian granite forming the base of the western slope. Other sediments, which are believed to be of Carboniferous (Redwall) age, occur in a ridge 2 miles southeast of Siam. These are slightly metamorphosed by intrusions of coarse granite and consist largely of quartzite and crystalline limestone. No fossils were found in them.

In the Randsburg district ${ }^{2}$ the oldest rocks are granite and schist. The relation between them is not distinct, but it is thought that the granite is probably older. The schists are largely mica albite schists, in places chloritic and locally gneissoid. Layers of quartzite and limestone occur in them. They are cut by masses of intrusive granite, which in turn cut and are cut by porphyritic and basic dikes. Greenstone intrusions also occur. The granites occupy the larger part of the area. Another series of sediments, consisting of fine-grained quartzite, siliceous shale, and limestone, somewhat altered, but undoubtedly younger than the schists, is found in the northwestern part of the district. A few specimens resembling fossils were found in these sediments and were determined as probably not younger than Carboniferous. These older rocks are overlain by friable yellow sandstones, probably of Tertiary age, which are cut through and overlain by lavas of many varieties, chiefly andesite, but also basalt. rhyolite, and probably latite and dacite. Unconsolidated sand and gravel form the latest deposits.

Mendenhall's work in the San Bernardino Mountains was done in an area about 80 miles north of west from the Eagle Mountains, and on this side also there has been no work done in the intervening area. The rocks of the San Bernardino and San Jacinto mountains are largely intrusive granitic and dioritic rocks belonging, perhaps, to the same period of intrusion as the granodiorite of the Sierra Nevada. On the north slope and locally on the south slope and in the central portion of the San Bernardino Range are sediments of all degrees of metamorphism, of unknown age, though older than the igneous rocks. Metamorphosed sediments that are older than the rocks of the San Bernardino Range occur in the eastern part of the San Gabriel Range and in places in the eastward extension of the San Bernardino Mountains and in the Cottonwood, San Jacinto, and Santa Rosa mountains. 
Locally on the lower slopes of the ranges there are slightly consolidated sediments of late Tertiary or early Pleistocene age.

\section{PRESENT INVESTIGATIONS.}

General succession of deposits.-During the field season, before and after mapping the Eagle Mountain iron ores, and while moving from one part of the iron-ore area to another, the writer traversed a considerable portion of the southeastern Mohave and Colorado deserts. During these trips, although the writer did not have in view any geologic reconnaissance work, he nevertheless examined the rock formations of the areas traversed, and as so little is known of the geology of this region it seems desirable to give a brief discussion of the rock formations noted.

The desert areas between the mountain ranges are covered to a great depth with unconsolidated desert deposits, and it is only in the mountains that the bedrock is exposed. As no fossils were found, the age of the various rock formations is unknown, and only their general relation to each other can be given. The section below shows very roughly the formations noted and their relative age.

General section of rocks in the southeastern Mohave and Colorado deserts.

10. Basalt.

9. Unconsolidated desert deposits.

8. Basalt; slightly tilted.

7. Partly consolidated shale, sandstone, and conglomerate; horizontal.

6. Trachytic, andesitic, and rhyolitic flows; tilted and broken; probably Tertiary.

5. Red and brown sandstone, shale, and conglomerate; tilted.

4. Intrusive granite, syenite, monzonite, and diorite and their porphyritic phases in sills, dikes, and irregular batholiths; probably Mesozoic.

3. Quartzites, crystalline limestone and dolomite and conglomerates; age unknown.

2. Purple and gray slates, shales, sandstones, and quartzites; age unknown.

1. Schists, crystalline limestone and dolomite, gneiss, and granite; probably pre-Cambrian.

These rocks are distributed through the ranges, some of which contain most of the formations in the series while others consist almost entirely of only one or two formations, so that it is difficult in many places to tell the relation between various rocks in the succession. The distribution of the rocks in the areas examined is shown below.

Amboy Basin.-A large part of the Amboy Basin south of the Santa Fe Railway between Amboy and Bagdad is covered with a very recent basaltic flow (stratum 10 of the above general section). Southwest of Amboy, in the midst of this area, is a large, symmetrical, black cinder cone, which is evidently the vent from which the lava flowed. The 
basalt area is surrounded by lake and outwash deposits, which probably also form the base on which the lava lies.

Sheephole Mountains.-The Sheephole Mountains where they are crossed by the Amboy-Dale stage road consist of coarsely crystalline granite (either stratum 1 or stratum 4 of the general section).

Mountains near Dale.-The Pinto Mountains contain quartzite, crystalline limestone and dolomite, and other metamorphosed sediments (3 of general section) intruded by granite, granite porphyry, diorite, and allied igneous rocks (4). In the range extending east and west from Dale no sediments occur, the entire range consisting of intrusive granitic and dioritic rocks (4).

Coxcomb Mountains.-The southern part of the Coxcomb Mountains consists of purple and gray shale, slate, and sandstone (2) as indicated by the material in the outwash aprons. It appears dark from a distance. The northern two-thirds of the range consists of a lightercolored rock, perhaps granite or quartzite.

Palen Mountains.-In the central part of the Palen Mountains there is a series of interbedded quartzite, shale, limestone, and gypsum (3), with intrusive diorite and rhyolite (4). North of this series is an extensive mass of coarse biotite granite (either 1 or 4), with abundant dikes of aplite. The granite and aplite apparently form most of the northern half of the range. South of the gypsum-bearing series the range appears to consist largely of argillaceous and arenaceous sediments (2), with intrusive granitic, dioritic, and allied rocks (4) as indicated by materials composing the outwash aprons. They are dark colored, like the formations in the southern part of the Coxcomb Mountains.

Maria Mountains.-The western part of the Maria Mountains consists largely of limestone, quartzite, and shale, with some gypsum (3) and areas of intrusive diorite (4). These rocks are a continuation of the gypsum-bearing series of the Palen Mountains.

Eagle Mountains. - The northeastern part of the Eagle Mountains consists of intrusive quartz monzonite (4) overlain at the northeast corner by basalt (8). South of the granite area is an area of quartzite, crystalline dolomite, and conglomerate (3), with large and small intrusions of quartz monzonite (4). The quartz monzonite becomes predominant to the south, containing only local areas of sediments. The sediments and intrusive quartz monzonite together form most of the northern part of the range, but in a few places they are overlain by basaltic and other flows and tuffs (8). They are cut by numerous dikes and irregular intrusions of aplite, syenite, diorite, and andesite porphyry. The southern part of the range consists largely of gneiss but contains some schist, quartzite, and granite (1). Small areas of gneiss and schist also occur within the sedimentary and igneous area in the northern part of the range. 
Cottonwood Mountains.-The entire width of the Cottonwood Mountains where the Mecca-Dale road crosses them consists of coarse granite, either 1 or 4.

Orocopia Mountains.-The eastern part of the Orocopia Mountains consists of andesitic and trachytic flows (6) on the south, and red and brown sandstones and shales (5) on the north. The sediments dip northwestward at varying angles, but their relation to the lavas is obscure. The formations continue southeastward into the Chocolate Mountains. South of the Orocopia Mountains and extending westward from them along the northern side of the Cochilla Valley are the so-called Mud Hills, consisting of deeply dissected, partly consolidated shale, sandstone, and conglomerate (7).

Chuckwalla Mountains.-The northwestern part of the Chuckwalla Mountains consists of granite (either 1 or 4 ), and perhaps some gneiss (1).

Chocolate Mountains.- The northwestern part of the Chocolate Mountains is made up largely of granitic and dioritic intrusives (4) and andesitic and trachytic flows (6). Sediments are found at the northwestern end near the Orocopia Mountains.

\section{PHYSIOGRAPHIC HISTORY OF THE DESERT REGION.}

The following series of physical changes have resulted in the development of the present topography in the great desert region of eastern San Bernardino and Riverside counties. After the last marked

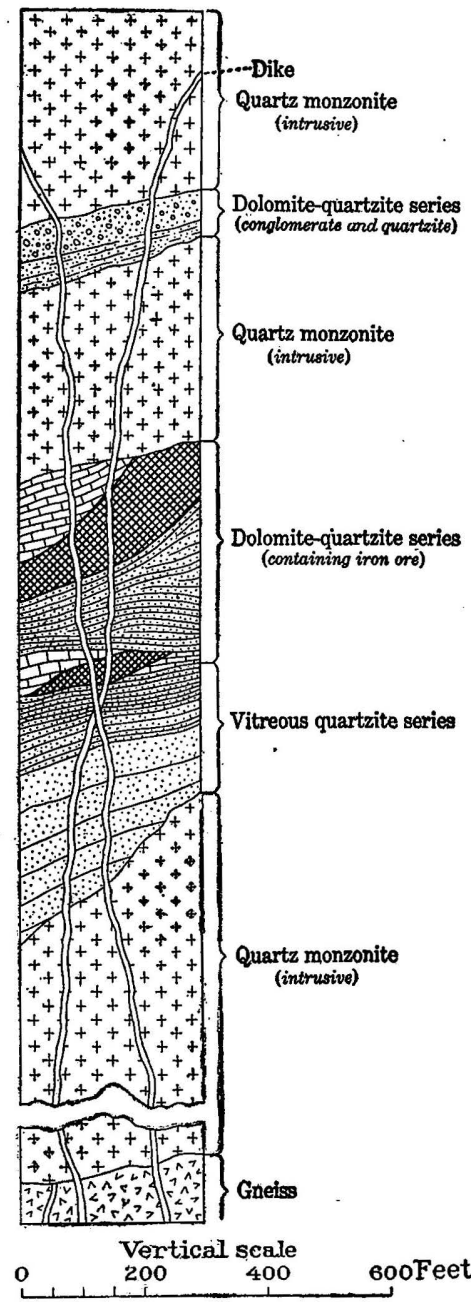

FIGURE 2.-Generalized section of the rocks of the Eagle Mountain iron-ore district. elevation of the rocks, in late Tertiary or early Pleistocene time, there was a long period of erosion, during which the elevated area was sculptured into mountains. Deep canyons were cut, and as erosion progressed broad valleys were formed here and there in the mountains. At this stage all the mountains in the southeastern 
Mohave and Colorado deserts were parts of one large, high, continuous range, similar to the present Sierra Nevada, to the north. This period of erosion was followed by a period of deposition, caused probably in a large measure by a gradual subsidence of the entire region, but perhaps also due in part to a change in climatic conditions from moist to arid. The material eroded from the high peaks was no longer carried away from the region by large streams but was deposited in the broad lower valleys. These were filled gradually to a great depth and the mountain ridges on either side became farther and farther separated. Local gravel deposits were formed in the high portions of the ranges and the streams became unable to carry the material away. The filled valleys are now represented by the broad, flat desert areas, and the small mountain ridges represent the higher peaks and ridges on the once extensive mountain mass. The subsidence was so great that many of the old valley bottoms are now many hundred feet below sea level. Locally, as in the Salton Basin, even the present surface of the filled valley is several hundred feet below sea level.

Recently there has locally been a lull in deposition and the filling is being eroded, as is shown by terraces on the sides of many of the present stream beds, by recent gorges cut into bedrock, such as that along the lower course of Placer Canyon, and also by short gorges in the outwash aprons. This newer cutting is due probably to tilting, caused mostly by recent faulting, as is indicated by the fact that the distribution of terraces is local.

\section{GENERAL GEOLOGY OF THE EAGLE MOUNTAIN IRON-ORE AREA.}

\section{ROCK FORMATIONS AND STRUCTURE.}

The broad structural feature of the northern third of the Eagle Mountains - that is, of the portion consisting of sediments and intrusive granite-is an oval dome, extending in a general east-west direction across the range. (See fig. 3.)

The broad end of the dome is near the western border of the mountains; the narrow end is buried underneath the outwash apron bordering the range on the east. The big dry wash cuts the eastern part of the dome in two, lengthwise. The exposure of the successive rock formations is roughly horseshoe shaped, with the opening to the east. Both the sediments and the intrusive quartz monzonite sills conform to this general structure, though faulting and irregularities in the intrusions have produced marked variations in the distribution of the rocks. In the center of the dome is a small lenticular area of old metamorphosed rocks consisting of gneiss in the western part and schist with quartzite and crystalline limestone in the eastern part. The gneiss is overlain by a thick series of vitreous quartzites, while 


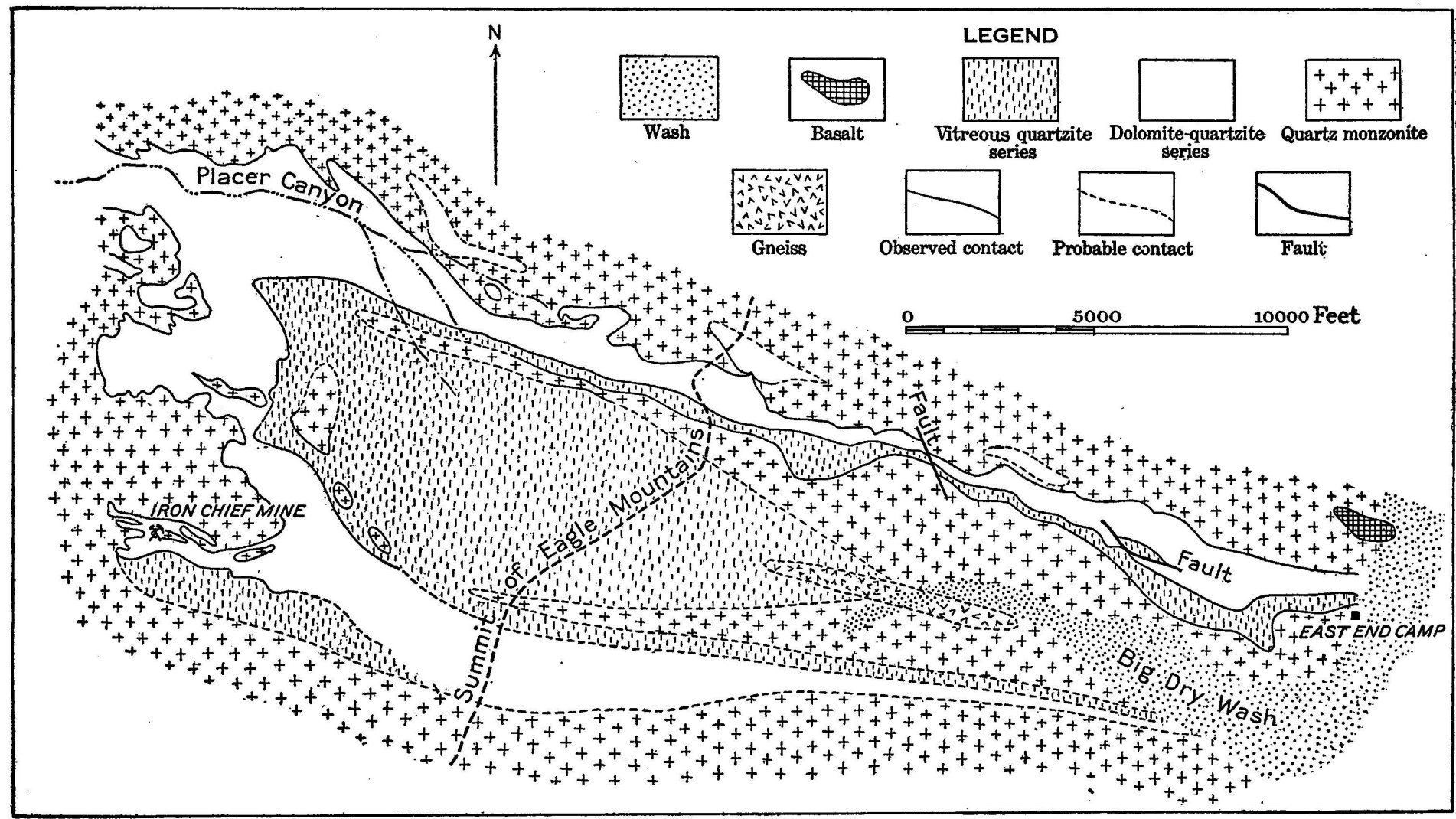


the schist at the eastern end is overlain by a great thickness of quartz monzonite, which is intruded, in the form of a sill, into or below the quartzite, at this point at its base, but farther west running up into the body of the quartzite. On both limbs of the dome the quartz monzonite which overlies the schist is in turn overlain by vitreous quartzite. Toward the west the quartz monzonite sill becomes thinner and has vitreous quartzite both above and below it. The lower 30 feet or more of the quartzite overlying the gneiss is locally pink and schistose, probably representing a zone of moviement during the doming. At other places the quartzite is massive and vitreous down to the gneiss contact. Above the vitreous quartzite is a series of schistose arkosic sandstones varying in thickness from 50 to 300 feet. These sandstones are immediately overlain by a series of interbedded lenses of quartzite and crystalline dolomite, the latter containing the iron-ore deposits. Overlying this series is another intrusive sill of quartz monzonite of great thickness in which there are areas of quartzite and conglomerate. The dip of sediments on the north and south limbs of the dome ranges from $20^{\circ}$ to nearly. vertical, but around the west end it is flatter. The general strike of the north $\operatorname{limb}$ is N. $70^{\circ} \mathrm{W}$.; that of the south limb is more nearly east and west. Numerous areas of intrusive quartz monzonite occur within the sedimentary area, and dikes of aplite, syenite, diorite, and andesite porphyry cut both the intrusive quartz monzonite and the sediments. Basalt and other flows locally overlie the older rocks.

The following is a general section of the formations composing the dome:

General section of rocks in the northern part of the Eagle Mountains.

5. Scoriaceous and massive basalt and other flows.

4. Quartz monzonite containing lenses of quartzite and conglomerate.

3. Quartzite, conglomerate, crystalline dolomite, ophicalcite, iron ore, and metamorphic minerals (mineralized rock). (Dolomite-quartzite series.)

2. Vitreous quartzite intruded by quartz monzonite and consisting of schistose-arkose in the upper part. (Vitreous quartzite series.)

1. Gneiss, schist, and quartzite, with locally thin layers of crystalline limestone.

The gneisses and metamorphosed sediments (1) belong under (1) in the general section for this part of the Mohave and Colorado deserts (p. 19). The other sediments (2 and 3) belong under (3) in the general section, and the intrusive igneous rocks ( 2 and 4 ) belong under (4). The basalt (5) is equivalent to (8). No fossils were found in any of the sediments of the district, hence the age of the rocks is unknown.

The belt of sediments on the south limb of the dome is very narrow at the east end and is bordered by wide areas of quartz monzonite on 
the north and south. The quartz monzonite area to the north is presumably continuous to the northern belt of sediments but is partly concealed by the gravels of the big dry wash. The sedimentary band consists of vitreous quartzite in the northern part and of quartzite with dolomite lenses in the southern part, with a band of arkosic sandstone between. The dolomite lenses are small and scattered. Farther west the belt becomes wider and the dolomite becomes more abundant and occurs over large areas. The quartz monzonite sill below (north of) the sediments becomes thinner westward from the gneiss-schist area, and after crossing the summit of the range becomes discontinuous, occurring only as scattered masses in the quartzite. The belt of sediments outcropping above the lower quartz monzonite sill on the north limb of the dome is very narrow throughout most of the eastern part of the area, though at the extreme east end it reaches a width of a third of a mile. North of it is a great thickness of quartz monzonite, occurring as a sill above the sediments. The sedimentary belt contains vitreous quartzite in its southern part, arkosic sandstone in its central part, and quartzite with dolomite lenses, largely replaced by iron ore and metamorphic minerals, in its northern part. Toward the summit the lower quartz monzonite sill gradually thins, as it does on the south limb, though beyond the summit it is more continuous than on the south side of the dome.

The central part of the domed area west of the summit and for some distance down the east slope is very largely vitreous quartzite. Local areas of quartz monzonite occur in it, however, chiefly along the general horizon of the lower quartz monzonite sill of the east side. The upper quartz monzonite sill is continuous around the west end of the domed area. It contains masses of quartzite and conglomerate in many places. The horizons of arkosic sandstones and of dolomite lenses are also continuous around the west end of the dome, though there are many local irregularities. At the west end the dip of the strata flattens somewhat, and hence the exposures are much wider.

Beyond the upper quartz monzonite, west of the dome near the western edge of the mountains, and also south of the domed area, there are several large areas of sediments, both quartzite and dolomite, probably brought up by faulting.

Late basalt and other flows overlie the upper quartz monzonite locally in the eastern part of the district, and dikes of different varieties cut the old metamorphic rocks, sediments, iron-ore deposits, and quartz monzonite.

IRON-ORE DEPOSITS.

The iron ores with associated metamorphic minerals occur as replacements in the dolomite. Locally, as at the east end of the area, they have replaced the entire series of dolomite lenses, leaving 
the associated quartzite but little altered. Elsewhere they occur within the dolomite lenses or beds in bands or as irregular masses roughly parallel to the bedding. All the deposits occur along the horizon of dolomite lenses, the principal ones being on the north limb of the dome. The trend of the iron-bearing belt along the north limit is approximately $\mathrm{N} .70^{\circ} \mathrm{W}$., its extent in this direction being about $6 \frac{1}{2}$ miles. Its width of outcrop varies from 500 feet to 2,500 feet. At the west end the horizon of dolomite lenses curves southward around the end of the dome in an irregular semicircle about 2 miles in diameter and then runs back eastward along the south limb of the dome, gradually getting nearer the north $\operatorname{limb}$, so that at the east end they are scarcely half a mile apart. It has a maximum width of about 4,000 feet at the west end but becomes thinner along the south limb. A westward extension of it, nearly a mile long, occurs at the southwest end of the dome, and on this is located the Iron Chief mine.

Small scattered iron-ore deposits occur in the dolomite belt at the west end of the dome and continue for half a mile eastward along the south limb. The rest of the south limb is almost barren of iron ore. Other deposits occur in the vicinity of the Iron Chief mine, in the westward extension, and in the outlying dolomite areas west of the dome. All of these deposits, however, are of little or no importance when compared with the extensive masses along the north limb, where there is an almost continuous series of deposits, occurring in some places in a single band and in others in two bands from several hundred to a thousand feet or more apart. The largest ore bodies are at the east end and the west end of this belt. Smaller ones occur at intervals between them. The largest body of mixed ore and gangue material is discontinuously exposed for a distance of about 6,000 feet and has a maximum width of outcrop of 500 feet. From this the deposits range down to a few feet in extent.

The ore is predominantly hematite, but here and there consists of masses of magnetite. Much of the hematite contains disseminated magnetite, making it slightly magnetic, but probably less than 10 per cent of the entire quantity of ore is magnetite. A considerable percentage is very pure and of high grade, containing between 62 and 67 per cent metallic iron and less than 0.06 per cent phosphorus. Much of the ore, however, is mixed with gangue material, such as metamorphic minerals and unreplaced rock. The principal minerals occurring with the ores and metamorphosed dolomite are serpentine, mica, amphibole, garnet, epidote, pyroxene, and titanite. 


\section{GÉOLOGIC HISTORY.}

The geologic events tabulated below have taken place in the Eagle Mountain iron-ore area:

Succession of geologic events in Eagle Mountain region.

1. Deposition of sandstone, siliceous shale, and dolomite.

2. Intrusion into the sediments of porphyritic granite.

3. Great dynamic metamorphism, resulting in the alteration of granite porphyry to augen gneiss and the sediments to schists and crystalline limestone.

4. Erosion interval followed by submergence and deposition of a great thickness of quartz sandstone; then the deposition of arkosic sandstone, followed by the formation of beds and lenses of dolomite and quartz sandstone, and, lastly, of beds of sandstone and conglomerate.

5. Intrusion of quartz monzonite in two main sills, one in the vitreous quartzite below the dolomite lenses and the other in the quartzite conglomerate beds above the dolomite lenses. The first is discontinuous, though locally of great thickness; the second is very thick and is continuous throughout the extent of the iron-ore belt.

6. The heat and pressure accompanying the intrusion recrystallized and consolidated the sediments and perhaps locally developed metamorphic minerals.

7. During the later part of the intrusion, or shortly after it, iron ores and metamorphic minerals were introduced by deep-seated solutions replacing the dolomite and to a slight extent the quartzite.

8. Doming of the sediments and intrusives, accompanied by great faulting.

9. Erosion exposing all the rock formations, accompanied by the sculpturing of mountains and followed by the development of great outwash aprons around the mountains.

\section{THE ROCKS.}

\section{OLD GNEISS, SCHIST, AND QUARTZITE.}

\section{DISTRIBUTION AND STRUCTURE OF THE GNEISS.}

Gneiss and schist with interbedded quartzite and crystalline limestone occur in a narrow lenticular area near the center of the domical uplift (fig. 3), the gneiss being in the western part and the metamorphosed sediments in the eastern part. The western end of the area is about half a mile east of the summit of the range.

The gneiss is exposed along the trail which crosses the summit about half a mile south of the iron-ore belt. The first exposures occur a short distance above the point where the trail leaves the big dry wash and enters the canyon, whence they continue about halfway up to the summit, where the gneiss is covered by the overlying vitreous quartzite. The quartzite surrounds the western part of the gneiss area on the south, west, and north. The eastern part, however, near the big dry wash, is bounded on the north and south by quartz monzonite, the quartzite on both sides having pinched out between the gneiss and the quartz monzonite. The gneiss area is bounded on the east by wash which separates it from the schist and quartzite area, 
and therefore the relation between the gneiss and the metamorphosed sediments could not be determined.

The gneiss is intruded by several varieties of dikes, which do not penetrate the overlying vitreous quartzite. The most conspicuous of these is a dark-green variety containing numerous small white feldspar phenocrysts.

The contact of the gneiss and the overlying vitreous quartzite is uneven, the uneveness being due partly to folding and faulting, but for the most part probably to erosion of the gneiss before the quartzite was laid down. The bedding of the quartzite dips slightly to the north. Local small outliers of quartzite are found in the gneiss area near its boundary. There is no conglomeratic or pebbly layer at the contact, and the only evidences that the gneiss is older than the quartzite and not intrusive into it are the facts that it is much more greatly metamorphosed and that it contains dikes which do not penetrate the quartzite.

In most places the quartzite immediately overlying the gneiss has the characteristic vitreous texture, but in a few places the lower 20 or 30 feet consist of the pink quartzite schist already mentioned and to be more fully described. (See p. 32.)

\section{PETROGRAPHY OF THE GNEISS.}

The gneiss is a coarsely crystalline grayish-pink rock, generally with a distinct foliated texture, due to the segregation of the darker minerals along irregular lines. It is squeezed and contorted and was formed by the regional metamorphism of a biotite granite. In most places the gneissoid texture is strongly developed, but in a few places where it is not so severely metamorphosed the original granitic texture is still apparent. In its most characteristic phase it is a typical "augen gneiss," the "augen" texture being caused by the presence of lenticular masses of quartz and feldspar bounded by thin, undulating layers of ferromagnesian minerals. Other phases of the gneiss show simple banding without development of the "augen" texture.

Its principal minerals are quartz and feldspar, but it contains considerable green biotite. Epidote, orthite or allanite (cerium epidote), magnetite, apatite, and titanite are present in smaller amounts. The quartz and feldspar compose about 80 or 90 per cent of the rock. They occur in grains of about the same size, but vary in relative abundance in different places. The biotite and accessory minerals occur in smaller grains, which are segregated along irregular lines in the quartz and feldspar.

The quartz occurs generally in large grains, but occasional small grains are included in the biotite and other minerals. It is nearly all clear and unaltered. Quartz also occurs in minute grains associated with sericite as an alteration product of feldspar. 
The feldspar is largely orthoclase, but perhaps a little albite is present. All of it is untwinned, however, and is cloudy and altered, presenting marked contrast to the clear quartz. The principal alteration product is sericite, but a little quartz occurs mixed with it, and locally there are masses of epidote.

The biotite is yellowish green to dark green and strongly pleochroic. It contains inclusions of apatite, epidote, titanite, and quartz. The included epidote generally occurs in irregular masses but is locally found as strips along the foliation planes. Most of it is apparently an alteration product, but part of it may be original. The other inclusions occur in disseminated grains.

The orthite or allanite is found in irregular grains or in large rectangular sections, generally associated with biotite. It is commonly surrounded by rims of epidote, which locally penetrate it. The allanite is strongly pleochroic, varying in color from grayish brown to dark chestnut-brown. It is not very abundant, occurring only at scattered intervals.

The epidote occurs mostly in irregular masses associated with the biotite, allanite, and feldspar and is apparently an alteration product of these. Locally, however, it is found in distinct prisms and is apparently original. Some of the epidote is colorless, but most of it shows yellow pleochroism.

Magnetite is found in irregular masses associated with biotite and also as small included grains in the biotite and allanite.

Apatite and titanite occur as included grains in the biotite and in small masses associated with the biotite.

\section{SCHIST AND QUARTZITE.}

The schist and quartzite series occupies the eastern part of the old crystalline area and is separated from the gneiss by the big dry wash, which crosses the area in a northeast-southwest direction, and is here about a fourth of a mile wide. The metamorphosed sediments are on the southeast side of the wash, and are bounded on the south by the quartz monzonite and on the north by wash. They dip at a slight angle to the south, the quartz monzonite apparently overlying them. Locally, a few areas of quartz monzonite occur between the wash and the schist series. North of the wash the quartz monzonite continues for over half a mile to the iron-ore belt.

The series consists of interbedded quartzites and gneissic quartzite schists, with local lenses and beds of serpentinized marble.

The quartzite schist is the characteristic rock of the series. It consists of alternating light and dark bands, the widest an inch or more in width, but most of them less than half an inch wide. The bands are very regular, and parallel to one another for considerable 
distances. The banding is caused by the segregation of dark minerals (biotite) more abundantly along certain layers than along others.

The rock consists largely of quartz with subordinate amounts of feldspar and biotite. The mineral grains differ in size in different layers; layers of fine-grained and coarse-grained material alternate. There is also a variation in mineral composition along different layers, quartz, however, being present throughout. Some layers contain abundant biotite, some contain abundant feldspar, still others consist entirely of quartz. The biotite is oriented parallel to the schistosity. The feldspar is largely orthoclase, but scattered grains of plagioclase (oligoclase) occur.

With decrease of biotite the quartzite schist changes into quartzite. This rock is not so abundant as the schist and occurs in beds in it.

The marble lenses interbedded with the quartzite are thin and of no very great extent. They are coarsely crystalline and contain an abundance of yellowish-green serpentine in nodules or layers, the largest several inches thick.

The entire series as exposed here is about 100 feet thick.

SEDIMENTARY ROCKS.

VITREOUS QUARTZITE SERIES.

DISTRIBUTION.

The vitreous quartzite occupies the west-central part of the domical area and extends eastward in two narrow bands, one on the north side and the other on the south side of the dome. (See fig. 3, p. 23.) There is also a smaller area at the southwest corner of the dome south of the strip of dolomite, on which is located the Iron Chief mine. The bands extending eastward from the main area are bounded below by quartz monzonite and above by the dolomite-quartzite series. The lower contact is very irregular, so that the bands vary in width from place to place.

The upper part of the vitreous quartzite series is composed of a varying thickness of thin-bedded schistose arkosic layers; the lower part consists of massive vitreous quartzite. In the narrow band which extends eastward from the main quartzite area along the north limb of the dome the upper arkosic phase is generally wider than the vitreous phase, and in a few places composes the entire band, the vitreous quartzite being cut out by the irregularity of the intrusion. The arkosic belt also extends with varying width around the west side of the dome and continues back along the south side.

Immediately above the schistose arkosic phase of the vitreous quartzite series is the lower dolomite bed of the dolomite snd quart- 
zite series. In a few places, however, this bed pinches out and the arkosic schists come directly into contact with the overlying quartzite.

The width of the arkosic schist band differs greatly in different parts of the district. Along the eastern portion of the northern limb of the dome it ranges in width from 80 to 200 feet, the dip of the rocks varying from $20^{\circ}$ to $70^{\circ}$ to the north. Toward the west the width of exposure increases, and in the center of Iron No. 27 it is 250 feet wide. Along the west side of the dome it locally reaches a width of 400 to 500 feet.

The vitreous quartzite phase is irregular in width along the northern sedimentary belt. In places it pinches out altogether between the schist belt and the quartz monzonite; elsewhere it reaches a width of 900 feet. In the western part of the belt, however, it extends entirely across the center of the dome, over 5,000 feet, with only local areas of quartz monzonite.

In the central part of the domical area the vitreous quartzite directly overlies a part of the gneiss area, and this is probably the basement on which it was laid down. Elsewhere in the district its base is not exposed.

character.

The vitreous quartzite series, as has been stated, consists of two main phases, a lower massive vitreous phase and an upper thin-bedded schistose arkosic phase. Locally near the contact with the underlying gneiss there is present a third phase, a pink schistose quartzite. The first two phases are distinct beds, but the third is irregular in its occurrence and apparently owes its origin to deformation.

No limestones or dolomites and practically no iron ores are found in the vitreous quartzite series. The only exceptions to this rule are a few small pockets of ore and masses of metamorphic rock developed locally where quartz monzonite intrusions occur in the upper schistose layers. Such occurrences are found at two places in the western half of the area, one on Syndicate No. 15 and the other on Iron Chief No. 1.

The vitreous quartzite phase consists essentially of massive beds of dense, hard, compact quartzite. Usually it is coarse grained, but local fine-grained phases occur. In many places it is so well recrystallized that the granular structure is hardly apparent and it has a glassy appearance. It varies in eolor from white to gray, yellow, or light brown.

Recrystallization has gone far toward obliterating original structures as well as textures, and in many of the outcrops it is difficult to distinguish the bedding. In general, however, it can be seen that it corresponds with the prevailing domical structure, though locally there are great irregularities of strike and dip. 
Later deformation, either accompanying the doming or occurring at some other time, has produced local secondary structure, chiefly jointing and slicing. Jointing is prevalent throughout the district but has no particularly noticeable features. Slicing, however, is apparently confined to the vitreous quartzite and is well developed only at a number of scattered localities. There is a remarkable correspondence in the direction of slicing in these different localities. Readings were taken at four or five widely separated points in the large quartzite area in the western part of the dome and along the north limb, and at each of them slicing was found, varying in direction between $25^{\circ}$ and $45^{\circ}$ west of north. There is as great a variation in the direction of this slicing at any one locality as there is between the different localities. At one of the places a few fractures had the direction $\mathrm{N} .15^{\circ} \mathrm{W}$. The dip of the fractures for the most part is nearly vertical, but-local variations were found down to $60^{\circ}$, the dips being generally to the north. The spacing of the fractures is usually very close but ranges from a fraction of an inch to several feet.

The pink schistose quartzite at the base of the vitreous quartzite along the contact of the underlying gneiss is locally absent, but in places it reaches a thickness of 30 feet or more. It was probably formed during the doming and represents points of more intense deformation, caused by greater movement locally along the contact of the basal complex and the overlying sedimentary rocks.

When examined microscopically the pink schistose quartzite is seen to consist largely of recrystallized quartz grains. Lines of shearing cut the quartz grains and intersect them irregularly, and along these lines sericite is developed abundantly. Magnetite occurs in scattered irregular masses and grains. Abundant, long, slender, needle-like crystals of colorless amphibole intersect the quartz grains in all directions. Irregular masses and minute particles of red iron oxide are associated with the sericite and locally scattered crystals of apatite and zircon are present.

The thickness of the vitreous quartzite phase is difficult to determine, because of the presence of the quartz monzonite intrusions in it. In the western part of the district its thickness probably considerably exceeds 1,000 feet; in the sedimentary belt extending eastward along the north limb of the dome its maximum thickness above the lower quartz monzonite sill is about 500 feet, and from this it ranges down to nothing.

The schistose phase of the vitreous quartzite series consists of variegated schistose arkoses and sandstones. Along the north limb of the dome east of the summit it ranges in thickness from 50 feet to $\mathbf{1 5 0}$ feet, being thinnest near the east end. South of Iron No. 27 
it reaches a thickness of over 250 feet; along the west side of the dome it is probably locally over 300 feet thick.

The upper portion of this horizon usually consists of a dark-banded arkose, locally schistose with abundant development of mica; the middle part of pink and yellow schistose sandstone; and the lower part of brown arkosic sandstone. Locally one or two of these may be absent and the other may make up the entire horizon. South of Iron No. 27, for instance, only the pink and yellow schistose sandstone is present but around the west side of the dome the dark banded quartzite is best developed. The upper banded quartzite characteristically contains thin sheets of intrusive coarse quartzfeldspar rock, a phase of the quartz monzonite (see p. 47), especially near and at the contact with the overlying dolomite-quartzite series. The following are typical sections taken along the northern sedimentary belt east of the summit.

Sections of the schistose phase of the vitreous quartzite series.

Section on Iron No. 4.

Greenish-gray banded arkose with sheets of quartz-feldspar rock . . 20

Pink and yellow schistose sandstone..................... 20

Dark brown sandy arkosic quartzite. . . . . . . . . . . . . 30

Section on Iron No. 8.

Dark micaceous arkose with sheets of quartz-feldspar rock........ 55

Pink and yellow schistose sandstone........................ 15

Yellowish brown sandstone............................. 5

Examined microscopically the schistose arkosic series is seen to consist in most places of quartz and altered feldspar so recrystallized as to yield locally a granitic texture and elsewhere a schistose texture. Generally, quartz is abundant, in many places forming more than one-half of the rock, but in local areas it is apparently entirely absent and the rock consists of feldspar and its alteration products. Judged by the texture and composition the original sedimentary nature of many of these phases is difficult to realize; in fact, some of them might be better explained as intrusive granitic and syenitic sheets folded and metamorphosed with the inclosing strata. Undoubtedly, however, judged by the major structures and the relation to the other rocks, the main portion of the arkosic series is of sedimentary origin. The most pronounced igneous phases occur in the upper beds, in which also occur the later intrusive sills of quartz-feldspar rock. The entire series, but especially the upper portion, has suffered pronounced alteration and hydrothermal metamorphism because of its proximity to points where the ore-bearing solutions have been active and because of the presence within it of an abundance of readily decomposable feldspar.

19557은 Bull. 503-12-3 
The upper dark beds of the schistose arkose consist in most places of quartz and finely granular sericite, the latter derived from the decomposition of feldspar. Some secondary quartz is locally intermixed with the sericite, and saussurite is present. In some places the sericite masses are irregular and no trace of the original feldspar remains; elsewhere they have the form of the original feldspar grains and inclose remnants of unaltered feldspar. In some of the phases orthoclase is present, not much altered, and intermixed with it are masses of sericite, representing probably the more readily altered lime-soda feldspar. In other phases both alkali and lime-soda feldspar occur but little altered. Orthoclase is generally the most abundant feldspar and in some places is present to the exclusion of lime-soda feldspar, and in a few places to the exclusion even of quartz. The feldspar and quartz grains are generally flattened parallel to the schistosity.

Besides the quartz and feldspar some biotite was present as an original constituent but is now in most places altered to epidote and chlorite. Zircon occurs locally as inclusions in the other minerals. Iron oxides, both hematite and magnetite, are present in scattered irregular masses.

Locally, in the upper portions of the bed, a number of secondary minerals were developed through hydrothermal metamorphism by the ore-bearing solutions, to which doubtless most of the sericitization should also be ascribed. The most important of these minerals are epidote, amphibole, muscovite, and titanite.

Epidote occurs in irregular masses, flattened parallel to the schistosity. Local veins of it cut the other minerals, showing that it was the last mineral developed. The amphibole is colorless or light bluish green, generally in distinct masses but here and there fibrous. Muscovite occurs in distinct flakes or in radiating masses. Most of it is partly altered to chlorite or serpentine. Titanite occurs in small scattered masses.

These secondary minerals are intermixed with recrystallized original minerals, in some places irregularly, in others along definite lines, producing lamination. They are only local in their development, being most common near the contact with the overlying series, where these have suffered the greatest metamorphism.

The pink and yellow schistose sandstone beds consist of quartz, sericite, and iron oxide. The quartz and sericite are about equally abundant, the sericite being in the form of a sort of irregular matrix in which the quartz grains are scattered. The sericite may have been derived from feldspar. Iron oxide is abundant, occurring in specks and irregular masses. Where the oxide is largely hematite and magnetite the rock is pink or reddish; where it is hydrated to limonite the rock is yellow. The hydration generally has taken place for 
varying distances from small fractures which traverse the formation as a close network.

The pink and yellow sandstone beds are very characteristic throughout most of the district, generally composing most and sometimes all of the upper arkosic phase of the vitreous quartzite. They exhibit well-developed schistosity, generally being finely laminated parallel to the bedding.

DOLOMITE AND QUARTZITE SERIES.

\section{DISTRIBUTION.}

The dolomite and quartzite series occupies the western part of the domical area and, like the vitreous quartzite, extends eastward in two bands, one along the north limb and one along the south limb of the dome. The bands are bounded above by the upper quartz monzonite intrusion and below by the arkosic phase of the vitreous quartzite series. The upper contact, being an intrusive contact, is very irregular, and locally masses of quartzite and conglomerate are found within the lower part of the quartz monzonite. The lower contact is generally regular and well defined and is usually at the base of the lower dolomite horizon or its altered equivalent. Because of the irregularity of the upper contact the outcrop of the dolomite and quartzite series differs greatly in width from place to place around the dome. At a point at the east end of the north limb it has a maximum width of 1,500 feet. Between this point and the summit of the range it ranges in width from 300 to 1,000 feet. Near the summit the width increases to 1,400 feet; farther west it ranges from 500 to 4,000 feet, reaching a maximum near the northwest corner of the dome. Around the west side of the dome the outcrop ranges in width from 3,000 to 4,000 feet, but the rock contains numerous irregular quartz monzonite intrusions. At the southwest corner the outcrop again becomes very narrow, reaching a minimum of 200 feet. On the Iron Chief group of claims it has a maximum width of 2,000 feet.

The uppermost known member of the series is a heavy-bedded conglomerate and quartzite; the lowest member is usually a dolomite bed or a series of dolomite lenses, more or less altered to iron ore and associated minerals. Between the two members lie beds of quartzite, dolomite, and limestone, irregularly distributed, the dolomite being in large part replaced by iron ore and metamorphic minerals. The conglomerate is only locally present in the main sedimentary area, for the most part being separated from it by varying widths of quartz monzonite, the separation being due to the irregularity of the intrusion. At places it lies within the upper quartz monzonite some distance outside of the area shown on the general map (Pl. I). The lower dolomite horizon also is locally absent by reason of nondepo- 
sition, being represented in parts of the district by a series of discontinuous lenses. The contact between the vitreous quartzite series and the dolomite and quartzite series is apparently conformable and the division is made simply on lithologic grounds in order to show the major structure of the district.

The lower dolomite horizon is partly replaced by iron ore and associated metamorphic minerals throughout the district and is entirely replaced in the eastern part of the north limb. The replacement and metamorphism of the sedimentary beds are discussed later (pp. 69-77), so the altered phases will be mentioned here only in a general way, the distribution of the different horizons being discussed irrespective of their metamurphism.

The lower dolomite horizon is narrow and at places discontinuous east of the summit, ranging in width from 75 to 150 feet, but farther west it is well developed, especially around the west end of the dome, where it locally reaches a width of over 1,000 feet. The great variation in width is largely due to the structure, but is also to some extent due to the variation in the thickness of the bed. The greatest widths are found where the dolomite is exposed along dip slopes of ridges; the narrowest parts occur where the bed dips into the ridges on whose slopes it is exposed.

In the eastern part of the district a variable width of quartzite lies north of the lower dolomite horizon. In a few places this quartzite pinches out, but in general its occurrence is rather regular.

The quartzite belt has a maximum width east of the summit of 700 feet opposite Iron No. 16; west of the summit it reaches a maximum width of 1,000 feet north of Iron No. 27. It contains numerous areas of quartz monzonite.

Above this quartzite there is another dolomite horizon, wider and more continuous than the lower horizon and also largely replaced by iron ore and metamorphic minerals. Locally the intervening quartzite pinches out and the two dolomite horizons combine into one. The widest lens in the upper dolomite horizon in the eastern part of the district lies just east of the summit and has a maximum width of 1,000 feet.

West of the summit the upper dolomite horizon becomes very irregular in its occurrence and locally there are several parallel outcrops. Elsewhere small scattered lenses of dolomite occur in the quartzite that intervenes between the two main dolomite horizons. Around the west end of the dome the structure is complex; and the uppor and lower dolomite horizons are difficult to separate.

On the north the upper dolomite horizon is usually bounded by quartz monzonite, though locally, as has been stated, the upper conglomerate and quartzite intervene between it and the quartz mon- 
zonite. Along the west side of the dome the upper quartzite and the conglomerate are exposed in several large areas west of the dolomite belt.

Character.

The dolomite and quartzite series consists of the following general succession from the base upward: (1) Crystalline dolomite containing locally layers of pure limestone and altered over large parts of the district to iron ore and associated metamorphic minerals; (2) finegrained and vitreous quartzite with local dolomite lenses and with phases of laminated cherty calcareous sandstone; (3) crystalline dolomite containing layers and lenses of ophicalcite and also altered over large portions of the district to iron ore and associated metamorphic minerals; (4) quartzite and conglomerate. The series ranges in thickness from 400 feet to 2,000 feet. It contains numerous intrusive masses of quartz monzonite and is cut by dikes of different varieties.

The lower dolomite or iron-ore horizon ranges in thickness from 50 to 125 feet in the eastern part of the district, but around the west end of the dome it reaches a thickness of 600 feet. The upper dolomite or iron-ore horizon ranges in thickness from 50 to 500 feet in the eastern part of the district, but around the west end of the dome it is generally combined with the lower horizon by reason either of the pinching out of the intervening quartzite or the complex structural relations. Locally in the eastern part of the district also the two dolomite horizons combine by the pinching out of the intervening quartzite.

Where unmetamorphosed by ore-bearing solutions the rocks of the dolomite horizons consist of white, yellowish, brownish, bluish, or pinkish-white dolomite, in most places coarsely crystalline. The prevailing type approaches very closely a pure dolomite in composition, but the amount of magnesium present varies somewhat in different beds. Along the west side of the dome about three-fourths of a mile south of Placer Canyon there is a horizon of pure dark bluish-gray, coarsely crystalline thin-bedded limestone, reaching in places a thickness of 50 feet, and exposed throughout an area about 1,500 feet in length. Other pure limestone beds, not noticeably different in appearance from the dolomite, may occur elsewhere in the district and have escaped notice. There may also be various gradational phases from limestone to dolomite. Analyses of dolomite and limestone from different parts of the district were made by George Steiger, of the United States Geological Survey, and the results are shown in the following table. For comparison, the composition of pure dolomite and calcite is also given. 
Analyses of dolomite and limestone from the Eagle Mountain district and of pure dolomite and calcite.

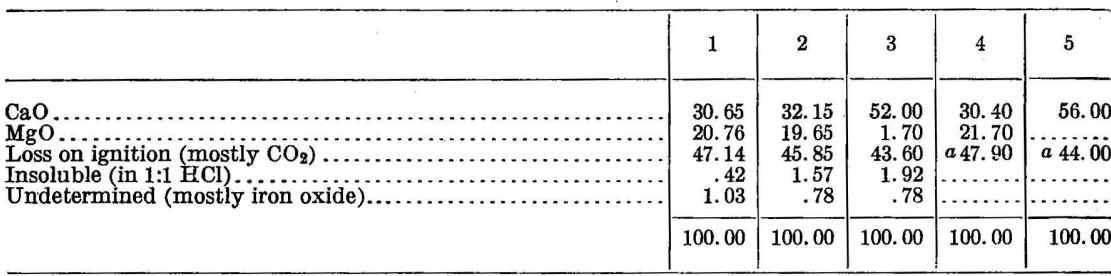

$a \mathrm{CO}_{2}$ only.

1. Coarsely crystalline white dolomite from large dolomite area on Iron No. 17, just east of the summit. (Specimen C, 145.)

2. Coarsely crystalline bluish white dolomite from ridge east of Iron Chief mine. (Specimen C, 172.)

3. Coarsely crystalline bluish-gray limestone from limestone horizon about three-fourths mile southsouthwest of Placer Canyon reservoir. (Specimen C, 82.)

4. Pure mineral dolomite $=(\mathrm{Ca}, \mathrm{Mg}) \mathrm{CO}_{3}\left(\mathrm{CaCO}_{3}=54.35 ; \mathrm{MgCO}_{3}=45.65\right)$.

5. Pure mineral calcite $=\mathrm{CaCO}_{3}$.

Analyses 1 and 2 are very near that of pure dolomite; analysis 3 is very near that of calcite. The amount of impurities present is very small and consists chiefly of silica and iron oxide. The silica is present largely in the form of silicates, very little pure silica occurring in most areas. The common silicates present are mica, pyroxene, and serpentine. Iron oxide is present both as magnetite and sesquioxide.

Microscopically the typical carbonate rocks are seen to consist of coarsely crystalline dolomite (locally calcite) in interlocking grains of very irregular size, the largest an eighth of an inch or more in longer diameter. Generally the carbonate grains are beautifully twinned, especially in the coarser varieties of the rock. In this crystalline base there are a few scattered impurities, mostly small specks of magnetite or hematite, locally partly altered to red iron oxide, which stains the surrounding carbonate. Pyrite also occurs in small specks, many of them altered to oxide. Small grains of quartz and pyroxene, flakes of muscovite and phlogopite, and bunches of serpentine áre found locally.

The carbonate rocks which are unaltered by ore-bearing solutions may be divided into three varieties, according to the impurities which they contain-(1) pure crystalline dolomite or limestone, (2) silicated pyroxenic dolomite, and (3) serpentinized dolomite or ophicalcite. Of these the pure dolomite is the most abundant, being distributed throughout the area of the dolomite-quartzite series. The pyroxenic dolomite and ophicalcite also are abundant, but are more local in their development.

The pyroxenic dolomite or marble is typically developed east of the Iron Chief mine, where thin layers and irregular masses of finely granular white pyroxene (probably diopside) occur in an otherwise nearly pure dolomite. (Analysis 2, above.) In some places they are 
close together; elsewhere they are widely scattered, and the prevailing rock is free from pyroxene. On the weathered surface the pyroxene bands stand up as ridges above the dolomite because of their lesser solubility.

The ophicalcite is most abundant and characteristic in the upper dolomite horizon and is typically developed at two localities-one where the dolomite band crosses the summit of the range and the other along Placer Canyon about half a mile east of the reservoir. It apparently occurs as local beds or lenses interlayered with pure dolomite. Some ophicalcite masses are exposed for a width of over 100 feet and for a length of 500 or 600 feet. They consist of a mixture of serpentine and crystalline dolomite, the serpentine occurring in the dolomite as nodules or as thin layers or various irregular forms, the largest several inches in thickness and of varying length. The serpentine is generally yellow to yellowish green in color, though some of it is dark, and to the naked eye appears compact and amorphous, but under the microscope it is seen to be composed of fine aggregates of radiating fibrous crystals.

The nodules are the most abundant as well as the most interesting forms in which the serpentine occurs. They are generally from an inch to 2 inches in diameter and are embedded in white crystalline dolomite. In the center of the nodule there is usually a core of unaltered white granular pyroxene, forming the nucleus. In some nodules the pyroxene core has entirely disappeared; in others it may be half an inch or more in diameter. This central core is surrounded by serpentine, with usually some intermixed masses of dolomite and numerous flakes of muscovite. In some nodules concentric layers of serpentine of varying fineness of crystallization bring out more definitely the nodular structure. Toward the outside the serpentine becomes more abundantly intermixed with dolomite and finally grades into almost pure dolomite with scattered rounded masses of radiating fibrous serpentine.

The quartzite intervening between the dolomite horizons reaches a maximum thickness of 800 feet and consists of fine-grained or coarsegrained vitreous quartzite with local phases of calcareous banded quartzite. The fine-grained and coarse-grained vitreous phases are widely distributed throughout the district, being interbedded with each other. The banded calcareous phase is found only locally, being typically developed for about half a mile east of the summit of the range. This phase is grayish brown in color and consists of interlaminated fine-grained siliceous and calcareous layers parallel to the bedding. The laminæ are generally thin and irregular, but locally there are beds of limestone with but little siliceous material, the largest a foot in thickness, between other beds which are predominantly siliceous. On the weathered surface the siliceous laminæ 
stand up as ridges above the more easily weathered calcareous portions.

The sediments above the upper dolomite horizon consist of interbedded quartzite and conglomerate. The quartzite is dense and finegrained, similar to that in the lower part of the series. The conglomerate consists of quartz pebbles in a white to greenish siliceous matrix, dense and compact. Locally the rock is so thoroughly cemented that the boundaries of the pebbles are indefinite, and it is difficult to distinguish between them and the groundmass. The fractures occur through the pebbles instead of around them. Considerable green amphibole is developed in the matrix, giving the rock a prevailing green color.

The metamorphism of the various sediments by heat, pressure, and the action of ore-bearing solutions is discussed in another place (p. 69), and will only be outlined in a general way here. Alteration by heat and pressure is widespread and has affected all the sediments, whereas metamorphism by ore-bearing solutions has been most profound along the dolomite horizons, so that at present the altered phases, consisting of ore and associated minerals, are as abundant and widespread as the original crystalline dolomite.

The metamorphism of the dolomite-quartzite series, which has resulted in the formation of dolomitic marble, silicated dolomite, ophicalcite, quartzite, and quartzitic conglomerate, is attributed to the heat and pressure accompanying the intrusion of the extensive quartz monzonite; that resulting in the formation of iron ore and associated metamorphic minerals is attributed to the action of the ore-bearing solutions and is believed to belong to a later stage of metamorphism.

The crystalline dolomite, the product of the first metamorphism, is widespread in the western part of the district, but toward the east it becomes less and less abundant, being replaced by iron ore and gangue, until at the east end of the district no dolomite is present at all and the horizons are occupied entirely by its alteration products.

The rocks which are most abundant in the altered phase of the dolomite are iron ore, consisting largely of hematite, but often with abundant magnetite; ferruginous dolomite, consisting of dolomite and iron oxides; magnetite-serpentine rock, consisting of magnetite and serpentine; tremolite rock, consisting of tremolite, anthophyllite, actinolite, hematite, and magnetite; muscovite-serpentine rock, consisting of muscovite, chlorite, serpentine, and magnetite; garnet rock, consisting of garnet, locally pure and elsewhere associated with abundant pyroxene, amphibole, magnetite, and hematite.

The alteration of the quartzite is less extensive than that of the dolomite, having occurred only locally and affecting but a small part of the total mass of quartzite. The most characteristic alteration 
products of the quartzite are epidote rock, consisting of epidote with locally abundant pyroxene or green amphibole; tremolite rock, consisting of tremolite, actinolite, and magnetite; and muscovite rock, consisting of muscovite and serpentine.

These various alteration phases are intermixed with each other irregularly, locally one and elsewhere another being predominant. In general, however, the characteristic alteration products of the dolomite in the eastern part of the district are iron ore, ferruginous dolomite, tremolite rock, and muscovite-serpentine rock, and in the western part iron ore, ferruginous dolomite, serpentine-magnetite rock, and minor quantities of garnet rock. The alteration products of the quartzite are tremolite rock and muscovite rock in the eastern part and epidote rock in the western part. There is no sharp line between the ore and the contact phases; they grade into each other with increase or decrease of iron oxides, and the same gradation occurs between various contact phases.

On the general map (Pl. I, in pocket) the iron ore is separated from the associated contact rocks, but the contact rocks are not separated from one another. This separation of ore and contact rock is only approximate, as many of the contact phases may be classified as lean ore. On the detail maps (Pls. IV, in pocket; V, VI, and VII, pp. 56, 58) several of the contact phases have been distinguished.

LATER FLUVIATILE DEPOSITS.

The later fluviatile deposits consist of débris from the mountains, which has been carried down the slopes during torrential rains and deposited in the arroyos or transported entirely outside the mountains and deposited as alluvial fans. Much fluviatile material is found in the bottoms and as terraces along the sides of the larger arroyos or dry washes. Some of them are half a mile or more in width and are apparently bottomed by a considerable thickness of gravel, sand, and bowlders. Along many of the arroyos there are gravel terraces, the highest 50 feet above the stream bed.

Alluvial fans spread out from the mouths of each of the arroyos and extend for miles down toward the center of the desert basin. The fans spreading out from neighboring gulches generally encroach upon one another and form a continuous alluvial apron along the edge of the foothills.

The fluviatile material in the terraces, the arroyo bottoms, and the alluvial aprons consists of rounded or subangular bowlders, pebbles, and sand grains. It is derived from the neighboring mountains and therefore consists of a mixture of the rock materials composing these. The largest bowlders are many feet in diameter, even along the alluvial aprons, having been carried out by streams during the torrential rains to which the desert region is subject. 


\section{IGNEOUS ROCKS.}

\section{GENERAL DISTRIBUTION AND CHARACTER.}

Igneous rocks of many varieties are found in the Eagle Mountain iron-ore district. According to occurrence they may be grouped under three heads: (1) Irregular intrusive bodies, (2) dikes and sheets, and (3) flows.

There are two principal intrusive bodies, one just above the ironbearing series entirely surrounding the domical area and one in the vitreous quartzite below the iron-bearing rocks, covering a large area within the dome in the eastern part of the district but becoming discontinuous to the west. Besides these there are a large number of small intrusions within the iron-bearing series between the two main bodies.' All the masses are apparently connected with the same period of intrusion and are doubtless derived from the same source. In mineral composition, however, the rocks of the different masses, as well as those within the same mass, differ considerably, grading from granite and soda syenite, through quartz monzonite, monzonite, and granodiorite, to quartz diorite. The prevailing rock, however, approximates in composition a quartz monzonite, and the term quartz monzonite is therefore used for the entire complex.

Dikes and sheets of several varieties of igneous rock cut the old metamorphic rocks, the sediments, and the quartz monzonite intrusions but are older than the flows. They occur throughout the district, but are probably most abundant in its eastern part. They vary greatly in composition, ranging from aplite through syenite to diorite. One or two varieties are present only in the gneiss, but the majority are present in all the other rocks except the flows. Those in the gneiss have been mentioned in connection with the gneiss (p. 28), and only those in the other rocks will here be considered.

Flows of massive and scoriaceous basalt are found at only one place in the iron-ore area, namely, in the upper quartz monzonite area just north of the easternmost extent of the iron-bearing belt. Other flows, however, both acidic and basic, occur elsewhere in the Eagle Mountains.

\section{INTRUSIVE QUARTZ MONZONITE.}

\section{DISTRIBUTION AND STRUCTURE.}

The quartz monzonite masses are roughly in the form of sills intruded into the sediments at certain horizons. This is true of the small masses in the iron-bearing series as well as of the two larger masses above and below them. Though occurring at definite horizons, they are in many places not parallel to the bedding, but cut across it obliquely. They also vary greatly in thickness in different parts and locally pinch out entirely. It is probable that beneath the 
surface along the dip similar conditions prevail and that sills cut across the bedding and thin and thicken irregularly.

The reasons for calling the large intrusive masses sills or sheets rather than irregular batholiths are (1) that though they cut across the bedding somewhat irregularly, yet they follow certain horizons rather definitely; (2) that in the eastern half of the district two narrow belts of sediments, one on each limb of the dome, representing a definite horizon in the sedimentary series, occur between two large masses of quartz monzonite for 3 or 4 miles, without being broken through, though they vary in width considerably; and (3) that, though the masses vary greatly in thickness, one dimension is always much smaller than the other two and that dimension is approximately perpendicular to the bedding of the rocks intruded.

The upper intrusive body is by far the most extensive. It occupies most of the northern portion of the Eagle Mountains, extending northward from the iron-ore district probably for several miles. Nothing is known of the rocks that occur beyond it except that basalt flows are found along the northern edge of the range.

South of the domical area also the quartz monzonite occupies a considerable stretch of country, in many places being probably a mile or more wide. It is locally covered by later flows, scoriæ, and agglomerate and is intruded in one place by a large body of aplite similar to that found in dikes in the iron-ore area. Farther south the quartz monzonite is bounded by an extensive area of old metamorphosed rocks-gneiss, quartzite schist, and quartzite - similar to those exposed in the center of the dome. These rocks probably occupy most of the southern part of the Eagle Mountains.

Around the west end of the dome the quartz monzonite occurs somewhat irregularly, but in places forms a belt half a mile to a mile wide. West of it lie areas of dolomite and quartzite which are similar to those composing the dome and which have doubtless been brought up by extensive faulting west of the dome.

Along the north and west side of the dome the upper quartz monzonite contains many large bodies of sediments, chiefly conglomerate and associated quartzite, which form the upper portion of the ironbearing series. These are the uppermost of the known sediments in the district. Locally they form the northern and western edges of the sedimentary area, but in most places they are separated from the other sediments by sills of quartz monzonite below the main quartz monzonite body.

The lower quartz monzonite is intruded into the vitreous quartzite series near its upper part, the upper contact being from 100 to 600 feet below the contact of the vitreous quartzite series and the dolomite-quartzite series. It is best developed in the eastern part of the dome, where it is a thousand feet or more in thickness. Near the 
summit it abruptly becomes thinner, and west of the summit it becomes discontinuous, occurring only as isolated masses at the same general horizon.

At the east end of the domical area the big dry wash conceals the axis of the dome, but quartz monzonite is exposed on either side of it and presumably underlies the wash. Farther west the schist and the gneiss are exposed along the axis of the dome, and from the east end of this area the quartz monzonite extends all the way to the sedimentary belt on either side, for a distance of half a mile or more to the north but not so far to the south. West of this point the sill gradually thins.

Quartz monzonite bodies of different shapas and sizes are numerous along the iron-bearing series. They are probably most abundant and irregular at a locality just west of the summit of the range and occur at intervals from this locality around the west end of the dome. (See Pl. I, in pocket.)

\section{PETROGRAPHY.}

As has already been intimated, the igneous intrusions, to which the term quartz monzonite is applied, are not composed of rock of a single distinct type, but consist of rocks of several transitional types, resulting from segregations within the masses. Besides this variation in mineralogical and chemical composition there is a considerable variation in texture. Though all the phases are phanerocrystalline, they range from fine grained to coarse grained and some portions of the masses are porphyritic, while others are even grained. The coarse-grained phases generally exhibit better developed porphyritic texture than the fine-grained phases.

The phenocrysts generally differ in size in rocks of different texture, being larger in the coarse-grained than in the fine-grained phases. In some of the coarser phases the largest are nearly an inch in longer diameter. The phenocrysts are feldspar, orthoclase being the most widely distributed and characteristic, though lime-soda feldspar phenocrysts are locally abundant.

The different types of the intrusive rocks range in composition from granite through soda granite, quartz monzonite, and granodiorite to quartz diorite, the quartz monzonite probably being the most widespread. With decrease in quartz the granite and soda granite grade into the corresponding syenites, while the quartz monzonite grades into monzonite. Diorites with little or no quartz were not found.

These various types are widely and irregularly distributed through a granite and quartz diorite complex and grade into one another through transitional phases. Some of the smaller intrusive bodies show but slight variation, but the larger bodies show a variety of types. The term quartz monzonite is applied to the entire complex for the sake 
of simplicity and because it is the average as well as the prevailing type.

The minerals composing the intrusive granite and quartz diorite complex are essentially lime-soda feldspar (oligoclase, andesine, labradorite), quartz, and alkali feldspar (orthoclase), with a subordinate amount of biotite and generally hornblende. Magnetite, pyrite, apatite, titanite, and rarely zircon are present as accessory minerals. Epidote is present locally in small amounts as an original constituent, but is generally abundantly present as an alteration product from feldspar and biotite. The feldspars are in many places strongly decomposed, generally yielding sericite or epidote, but locally being altered to saussurite, in which zoisite is well developed. Biotite is generally more or less altered to chlorite or to epidote. Hornblende is locally altered to epidote or to fibrous, colorless amphibole, rarely accompanied by carbonates. The accessory minerals occur in small, irregular masses scattered through the other minerals or as included grains in them.

The quartz monzonite, the most abundant phase in the granitequartz diorite complex, consists chiefly of lime-soda feldspar (oligoclase, andesine, and labradorite) and quartz with varying, though generally considerable, amounts of orthoclase. With decrease of orthoclase granodiorite is formed, and with little or no orthoclase present quartz diorite is formed. With increase of orthoclase and decrease of lime-soda feldspar granite is formed, with the transitional phase soda granite where the most abundant feldspars are oligoclase and albite. Where the quartz decreases in amount transitional phases toward monzonites occur; with a decrease of quartz and an increase of alkali feldspar soda syenite and syenite result.

The ferromagnesian minerals, biotite and hornblende, vary in abundance locally, in places forming a notable part of the rock and elsewhere being relatively scarce. They are brown or green biotite and green hornblende. Pyroxene was not found in any of the rocks examined. Hornblende and biotite are usually present together, but locally biotite is present to the exclusion of hornblende. Magnetite, apatite, titanite, and rarely zircon are the accessory minerals. Epidote, chlorite, fibrous amphibole, sericite, and saussurite occur abundantly as alteration products of the original minerals.

Andesine is the characteristic feldspar, but either or both oligoclase and labradorite may be abundant. In most places the feldspars have undergone considerable decomposition, the lime-soda feldspar much more extensively than orthoclase. The typical and most widespread decomposition product is white mica or sericite in aggregates of minute grains or small flakes. Epidote in granular agregates is also widespread, but is present in smaller quantities and generally accompanies the sericite. In places in the more basic feldspar saus- 
surite is associated with the sericite and the alteration material is a granular mixture of sericite, zoisite, secondary albite, and epidote. Inclusions of quartz and feldspar are common in many feldspars, especially in orthoclase, in which inclusions of twinned feldspar frequently occur. Orthoclase is most abundant as phenocrysts, and lime-soda feldspar is generally most abundant in the matrix.

The quartz is generally clear and unaltered, even in rock in which the feldspar is strongly decomposed. Frequently the quartz and the orthoclase are fresh and the plagioclase feldspars are altered. The quartz occurs generally in irregular grains, different parts of some grains having different orientation.

The characteristic biotite is the brown variety, strongly pleochroic, varying from light brown to very dark brown. Some specimens contain abundant green biotite, which is probably an intermediate product between the brown biotite and its alteration product, chlorite. In most of the specimens the biotite is partly and in some of them entirely altered to chlorite. The chlorite also is strongly pleochroic, varying in color from light yellowish green to dark emerald-green. It has exactly the form of the biotite which it replaces. In the partly decomposed biotite there are alternating streaks of chlorite and biotite lying parallel to the cleavage. Epidote is in some specimens abundantly associated with chlorite, being also an alteration product of biotite. The biotite contains abundant inclusions of apatite, and some specimens contain titanite.

Amphibole is present in nearly all of the quartz monzonites. The most common form is green hornblende, which is associated with the biotite, either in greater or equal amounts, or, most generally, in subordinate amounts, or locally it is absent altogether. It is pleochroic and varies in color from light green to olive green or dark bluish green. It is generally fresh but is locally altered to fibrous colorless amphibole, chlorite, epidote, quartz, and carbonates.

In several specimens a colorless amphibole was observed both as compact crystals and as fibrous aggregates, the latter plainly secondary after green hornblende, with recrystallization. Many of the fibrous crystals cut quartz and feldspar, and with them epidote is commonly associated.

Epidote is abundantly present as an alteration product from feldspar and biotite, but rarely it has crystal forms and is apparently original. It occurs either in distinct masses or in granular aggregates, the former associated principally with the ferromagnesian minerals and the latter occurring as a decomposition product of feldspar. In places epidote occurs in veins that cut all the other minerals and are a product of secondary infiltration. The epidote may be colorless or yellow and pleochroic. In a few specimens the cerium epidote, allanite, was seen, epidote being associated with it. Magnetite, 
titanite, and apatite are found in irregular masses associated with the ferromagnesian minerals, but more commonly they occur as small grains included in the other minerals. Zircon occurs as included grains, but is rare.

The other phases of the granite and quartz diorite complex differ but slightly from the prevailing quartz monzonite type. In the quartz diorite labradorite and andesine become the predominant feldspars; in the granite orthoclase is the important feldspar. In the syenite and monzonite quartz is relatively scarce as compared with the feldspars.

There is no regularity in the distribution of ferromagnesian minerals in the different types, as they vary in abundance in different parts of the acidic as well as of the more basic phases.

The color of the rocks is generally grayish, ranging from light to dark with the quantity of ferromagnesian minerals present. The gray color is generally somewhat modified by pink or green tints, the pink resulting from the presence of iron oxide and the green from partial alteration to epidote.

The different phases of the quartz monzonite masses were doubtless intruded at the same time, their variation in composition being due to segregation. The various intrusive masses probably came from the same magma reservoir, and the segregation may have taken place in this reservoir prior to the intrusion or may have occurred after the intrusion.

\section{FELDSPATHIC PHASE OF QUARTZ MONZONITE.}

At the contact of the schistose arkosic upper portion of the vitreous quartzite series and the overlying dolomite and quartzite series, and also in the upper portion of the schistose arkose, there are thin sheets of a characteristic quartz-feldspar rock, probably a phase of the quartz monzonite, which it resembles in all respects except in the relative abundance of ferromagnesian minerals. The quartz-feldspar rock, though characteristically associated with the contact of the two sedimentary series in parts of the district, is not everywhere present. It may be absent for considerable distances, but considering its thickness, which in few places exceeds more than a few feet, its widespread occurrence is remarkable. Although its average thickness is small, it is in a few places perhaps as much as 10 feet thick. Locally it is associated with quartz monzonite intrusives in the dolomite-quartzite series, especially near the contact of such masses with limestone.

The quartz-feldspar rock shows variations of texture and composition similar to the rest of the phases of the quartz monzonite complex. In texture it ranges from fine grained to extremely coarse grained, the coarser textured phases containing crystals having a 
larger diameter of nearly three-quarters of an inch. In composition, as its name indicates, it consists largely of quartz and feldspar, the feldspar generally predominating. It contains scattered ferromagnesian minerals-biotite and green amphibole or pyroxene (augite). The several varieties of feldspar occur in different quantities in different specimens of the rock; in some orthoclase is predominant; in others the lime-soda feldspar, andesine, prevails. In some specimens orthoclase occurs in phenocrysts and lime-soda feldspar and quartz form the coarsely crystalline matrix. The feldspars are generally somewhat cloudy from alteration, the lime-soda feldspars more so than the orthoclase. The alteration products are sericite, epidote, and saussurite, and zoisite is well developed. In some specimens epidote is inclosed in large masses in the feldspars, and the other alteration products occur in granular aggregates. Epidote also occurs in veins that cut the other minerals. The ferromagnesian minerals are generally much altered, the alteration products of biotite being chlorite and epidote, and those of pyroxene being epidote and iron oxide. Scattered masses of titanite and included grains of epidote occur sparingly.

\section{EPIDOTIC PHASE OF QUARTZ MONZONITE.}

Another phase of the quartz monzonite, more local in its development than the feldspathic phase, is the epidotic phase, an epidotequartz rock or epidote-amphibole rock. This phase is the result of metamorphism of the larger quartz monzonite intrusions along the contact with sediments, especially the dolomite, and will be more fully discussed in the general section on metamorphism (p. 72).

The epidote rocks occur as irregular scattered masses in an altered quartz monzonite zone of varying width, which is locally developed at the contact with the sediments. In some places this altered zone has a width of several hundred feet, but in many places it is absent altogether. It consists largely of typical quartz monzonite, which incloses irregular masses of altered sediments and local bunches of altered quartz monzonite-that is, epidote rock.

The epidote rock is bright green and may consist of pure epidote or of epidote mixed with quartz or dark-green amphibole, probably hornblende. Locally the amphibole may be in excess of the epidote and the rock becomes dark green. Small specks of pyrite are disseminated through the rock.

\section{DIKES AND SHEETS.}

\section{CHARACTER AND DISTRIBUTION.}

The dikes range in composition from aplite and syenite to diorite, this range being similar to that of the large intrusive bodies described as quartz monzonite. They differ from those, however, in the fact 
that the prevailing types in the large intrusions are intermediate in composition between granite and quartz diorite, whereas the most abundant dikes are prevailingly aplites and diorites.

In mapping the dikes and sheets they have been separated into aplite dikes, gray dikes, and green dikes and sheets. The aplite dikes include the acidic phases, which consist largely of quartz and alkali feldspar, chiefly orthoclase. The gray dikes include fresh unaltered dikes of quartz diorite and andesite porphyry. They differ somewhat among themselves in texture, but have very similar mineral composition. The green dikes and sheets include various epidotized and otherwise altered sills and dikes and range from syenite to diorite. They also include certain scapolite-pyroxene rock dikes. The gray and the green dikes are distinguished from one another by texture rather than by original composition, as the green dikes include various phases of altered diorite and andesite porphyry.

\section{APLITE DIKES.}

Distribution.-The aplite dikes are confined largely to the eastern half of the district, where, however, they are very abundant. In the area west and northwest of East End camp large aplite dikes cut both sediments and quartz monzonite. The largest of these has a maximum width of 75 feet and is nearly 700 feet long and occurs in the quartz monzonite just north of the iron-ore belt near the edge of the desert. Other large dikes and a few irregular bodies of aplite are found in the quartz monzonite farther north and at various places in the quartzite and iron ore belt farther south and west. Most of these cut the quartzite, but a few cut the ore bodies also.

Other aplite dikes and irregular masses are found at intervals along the sedimentary belt between Iron No. 8 and the summit. These differ somewhat in texture from the aplites of the East End but have approximately the same mineral composition. The aplites of the East End are white to grayish, but those near the summit have a pronounced purple tint.

Petrography.-The aplites of the East End consist largely of quartz and feldspar. Biotite occurs sparingly in them, and magnetite, muscovite, and epidote are minor minerals. Apatite and zircon occur as inclusions in the other minerals.

The feldspar is predominantly orthoclase, but scattered plagioclase (oligoclase) occurs. Most of the feldspar is fresh, but some, principally lime-soda feldspar, is slightly altered to white mica (sericite) and epidote.

The biotite is in places partly altered to chlorite and with it are associated small particles of epidote, also probably derived from it by decomposition.

$19557^{\circ}-$ Bull. $503-12-4$ 
The rock has a fine-grained granitic texture, the feldspar generally having crystal outlines and the quartz filling the spaces between.

The aplites west of Iron No. 8 differ considerably in texture from those at the East End, their striking characteristic being beautifully developed micrographic intergrowths of quartz and orthoclase. These intergrowths make up the larger part of the rock mass. The rest of the mass is composed of irregular grains of quartz and feldspar and scattered amphibole and titanite. Certain of the feldspars are almost entirely altered to sericite and saussurite, being probably lime-soda feldspars, as some of them still show traces of twinning. The amphibole is colorless to light green and generally somewhat decomposed.

\section{GRAY DIKES.}

QUARTZ-HORNBLENDE DIORITE.

Distribution.-Quartz-hornblende diorite dikes are found only in the western part of the district, where they occur along a definite line cutting diagonally across the end of the dome in a direction about N. $60^{\circ}$ to $65^{\circ} \mathrm{E}$. The line of dikes enters the district just west of the Iron Chief mine and leaves it through the western part of Syndicate No. 28. In some places through this extent there are several parallel dikes, 10 to 20 feet wide; elsewhere there is only one dike. In some places no dikes are present for considerable distances. The longest single dike of quartz-hornblende diorite mapped in the district is about 1,500 feet long and the widest one over 100 feet wide. Locally, the intrusions are in the form of small elliptical masses rather than dikes.

Petrography.-The quartz-hornblende diorite dikes show the same texture and mineral composition throughout their extent. They are phanerocrystalline but very fine grained and nonporphyritic and are of dark gray color. They consist principally of feldspar, quartz, and hornblende. The feldspar and hornblende commonly have crystal outlines and irregular grains of quartz fill the spaces between them. Magnetite, titanite, and apatite are accessory minerals, and chlorite, epidote, sericite, saussurite, and calcite occur as alteration products.

The feldspars are largely lime-soda feldspars of the variety oligoclase-andesine. The twinning is poorly developed in them and locally they are strongly decomposed. A small quantity of orthoclase is present. The alteration product of the feldspar is a mixture of sericite, epidote, and, locally, saussurite in aggregates of small flakes and grains.

The hornblende is of the brown variety and occurs in elongated tabular forms. Much of it is altered to chlorite and epidote, which are associated with it in distinct masses of irregular outline. Some of 
the epidote may be an original constituent of the rock. The hornblende is very abundant, giving the rock a dark color.

The calcite occurs in irregular masses with indistinct boundaries and is not very abundant. The accessory minerals occur as inclusions in other minerals and as irregular masses.

ANDESITE PORPHYRY.

Distribution.-Dikes of andesite porphyry occur at intervals throughout the district but are most numerous in the western part, only a few being found along the iron-bearing belt east of summit. Most of them are narrow, though some are of great length, one in the area east of the Iron Chief mine being nearly 2,000 feet long. The andesite porphyry dikes are closely related to the quartz-hornblende diorite dikes but are less restricted in their occurrence.

Petrography.- The andesite porphyry dikes are very similar to the quartz-hornblende diorite dikes in mineral composition but differ from them in texture. They are porphyritic and have an aphanitic to finely crystalline groundmass. The kind of phenocrysts differ in different dikes; some have hornblende with little or no feldspar; some have feldspar with but little hornblende; others have both feldspar and hornblende abundantly. Locally phenocrysts of biotite are abundant. In some places the phenocrysts make up nearly one-half of the rock mass; elsewhere they are present in subordinate quantities. The hornblende phenocrysts are lathlike and the largest are two-fifths of an inch in length; the feldspar phenocrysts are thicker, the longest being one-fifth of an inch in length.

Most of the feldspar phenocrysts consist of labradorite, but andesine occurs and locally some orthoclase. Zonal structure is well developed in them and some in the outer zones have a different texture from those in the interior, being frequently untwinned and probably having a different composition. Many of the feldspar phenocrysts are strongly decomposed, the inner portion being more altered than the outer portion. In some the interior is a mass of alteration minerals and the outer rim is quite clear and fresh.

The alteration products are sericite, quartz, and saussurite, and zoisite and epidote are well developed. The alertation products of feldspar generally occur in mixed granular aggregates, but sericite frequently occurs in large flakes.

The hornblende and biotite are both of the brown variety, and both are altered to a greater or less degree to chlorite and epidote, chlorite being the more common alteration, but epidote being very abundant locally. Both chlorite and epidote occur in distinct irregular masses.

The groundmass is largely lime-soda feldspar and some orthoclase and ferromagnesian minerals-hornblende and biotite. Quartz 
occurs in small scattered grains; magnetite, pyrite, apatite, titanite, and zircon are accessory minerals. The feldspars and the ferromagnesian minerals are locally largely altered to their decomposition products. Calcite is found in scattered irregular masses.

GREEN DIKES AND SHEETS.

DISTRIBUTION.

The green dikes and sheets of syenite porphyry, microsyenite, microdiorite, and andesite porphyry are very abundant in association with the iron-bearing series, being especially characteristic of the upper ore horizon but also occurring in the lower horizon, as on Iron Nos. 26 and 27. They occur apparently in dikes and irregular intrusive sills, which in some places follow definite horizons along the ore-bearing series and in others cut across them at small angles. In the eastern part of the district the sills occur characteristically along the contact of the upper ore horizon and the quartz monzonite. They send off small dikes both into the ore and sediments and into the quartz monzonite.

The green dikes of scapolite-pyroxene rock were noted only at the east end of the iron-ore belt.

\section{PETROGRAPHY.}

Soda syenite porphyry and microsyenite.-The soda syenite porphyries are greenish-white to greenish-gray porphyritic rocks with aphanitic to finely crystalline groundmass. In some phases the phenocrysts are large and abundant but in other phases they are few and scattered and locally are absent altogether.

The phenocrysts consist of feldspar, in some phases oligoclase and albite, in other phases orthoclase. The largest are a fifth of an inch in the long diameter and are generally considerably altered. The alteration products are sericite, epidote, and saussurite, in varying abundance, occurring as disseminated grains or as granular masses. Some epidote and zoisite masses of considerable size occur in the phenocrysts.

The groundmass contains both alkali and lime-soda feldspars but consists principally of orthoclase with locally abundant albite and oligoclase. In some phases much andesine is present. Other minerals in the groundmass are colorless to light-green fibrous amphibole, epidote, chlorite, muscovite, pyroxene, and titanite. Some of the amphibole masses contain remnants of brown hornblende and some have hornblende outlines showing that they weré probably secondary from hornblende. Generally, however, the amphibole is in irregular fibrous masses. The epidote is also probably secondary and occurs in irregular masses associated with chlorite and amphibole. In some of the microsyenite phases pyroxene is very abundant 
and occurs in irregular masses and grains intermixed with feldspar. Often pyroxene crystals occur in groups. They are generally but little altered except locally to chlorite.

Microdiorite.-The microdiorite dikes and sheets are generally narrow and are not continuous through a great distance. They consist of fine-grained, dense, compact rocks ranging in color from light green to very dark green, and rarely are slightly porphyritic. Many of them are strongly epidotized. By far the most abundant of the microdiorite dikes are nonporphyritic and have an aphanitic to finely crystalline texture.

The phenocrysts are few and scattered and consist of feldspar. Most of them are twinned lime-soda feldspars but scattered untwinned feldspars occur. Many of them have been partly altered to sericite and saussurite.

The groundmass of the microdiorites consists largely of lathlike interlocking crystals of feldspar and brown hornblende. The feldspars are mostly andesine and labradorite. The hornblende is strongly epidotized and chloritized but the feldspars are generally fresh. The epidote and chlorite occur in large, irregular masses and associated with them in many of the phases is a light-green to colorless fibrous amphibole in irregular masses and scattered needles. Magnetite is commonly present and is partly altered to red iron oxides.

Andesite porphyry.-The green andesite porphyry differs from the gray andesite porphyry in being much altered. It is found only in the eastern part of the district, where it occurs over a small area.

It is a dark-green porphyritic rock with an aphanitic groundmass. The phenocrysts are feldspar, all much altered and some entirely decomposed. They are very abundant, making up probably oneeighth of the rock mass, and the largest are two-fifths of an inch in diameter. The alteration product of the feldspar is mostly saussurite, consisting largely of zoisite. Sericite and epidote are locally abundant. Most of the phenocrysts appear to be labradorite, bordering on bytownite.

The groundmass consists mostly of feldspar, but contains abundant fibrous secondary amphibole. Epidote, chlorite, and quartz occur more sparingly. The feldspars in the groundmass are largely of the lime-soda variety, but include considerable alkali feldspar. In some of the phases a few of the fibrous amphibole masses contain remnants of unaltered brown hornblende; in others hornblende crystals are still abundant.

Scapolite-pyroxene rock.-Near the east end of the iron-ore belt there are several narrow dikes of dense green vitreous rock of peculiar composition, which cut ore, quartzite, and quartz monzonite but are cut by other green dikes, such as andesite porphyry and microdiorite. 
This rock consists mostly of scapolite and pyroxene (probably augite). The scapolite is in large masses having irregular outlines; the pyroxene is in smaller irregular masses and grains, which are included in the scapolite masses or lie between them. Some individual pyroxene crystals are grouped in bunches. The scapolite is generally predominant, but the pyroxene is also abundant.

For the most part the rock is little altered, but some of the pyroxene is partly altered to chlorite.

Besides the scapolite and pyroxene, irregular masses of titanite are locally abundant and scattered masses of apatite frequently occur. In some of the phases much-altered feldspar is intermixed with the scapolite.

\section{BASALT FLOWS.}

Basalt flows occur only at the extreme eastern end of the iron-ore district, where isolated masses cap a few ridges and knolls. They have an irregular contact with the underlying rocks, dipping about $10^{\circ} \mathrm{E}$., toward the desert. The flows are underlain by the upper quartz monzonite, here consisting largely of quartz diorite and containing dikes of aplite.

The lower few feet of the basalt consist of red agglomerate and tuffaceous rock, and above this lie 3 or 4 feet of light-colored banded material. The main lower part of the flow as exposed consists of dark scoriaceous basalt containing an abundance of amygdules, the largest an inch or two in diameter. The rock between the amygdules is dense and aphanitic. Many of the amygdules contain a lining of powdery calcite. Interbedded with the scoriaceous basalt are one or two thin layers of light-colored tuff. The main upper part of the flows as exposed consist of dense porphyritic olivine basalt containing only small, scattered amygdules. The entire thickness of the basalt flow is less than 150 feet.

The olivine basalt has a dark-brown, dense, aphanitic groundmass, through which are scattered abundant phenocrysts of olive-green olivine, the largest an eighth of an inch in diameter, and a few scattered large phenocrysts of feldspar. In the rock are scattered cavities lined with calcite.

The groundmass forms a much larger percentage of the rock than the phenocrysts and consists of well-crystallized feldspar, pyroxene, olivine, and magnetite. Calcite occurs in a few irregular, ill-defined masses.

The feldspars in the groundmass.are clear and unaltered and nearly all show twinning. Most of them are labradorite, but there are gradations toward andesine and bytownite. The pyroxene. is augite, light gray in color, and unaltered. It is less than half as abundant as the feldspar and has less well developed crystal forms. 
The augite and labradorite grains are of about the same size. Olivine is next in abundance in the groundmass. It occurs in scattered, irregular grains. The olivine in the groundmass and in the phenocrysts shows alteration to reddish-brown iddingsite. Some are altered only around the borders; others are almost entirely altered. Most of the olivine phenocrysts show resorption. Magnetite occurs in small irregular masses, in places filling interstices between other minerals, in others cutting across them. Some olivine phenocrysts have minute included grains of magnetite.

At places in the Eagle Mountains outside the district there are areas of different kinds of effusives. At the north end of the Eagle Mountains there are scoriaceous basalts and in the central portion, south of the iron-ore district, there are light-colored tuffs and purple flows.

\section{RELATION OF DIKES AND MAJOR INTRUSIONS.}

The general similarity in the range of composition of the large quartz monzonite intrusions and the various dikes suggests that they may be related in origin. The dikes, however; are all later than the sills and cut them in all directions. Hence they have not acted as vents through which the quartz monzonite was intruded. In fact, vents were not observed at any point in the district. It is possible, however, that the quartz monzonite and the dike rocks came from the same magma reservoir, the various dikes representing later differentiations in the parent magma after the extrusion of the great quartz monzonite masses. The formation of the dikes must have taken place a long time after the extrusion of the quartzmonzonite masses, however, as the quartz monzonite had become completely solidified and the iron ores had been formed in the meantime.

Whether any relation exists between the dikes and the effusives of similar composition of this region is not known, as no such rocks occur within the district and those outside of the district were not examined in detail. It is very likely, however, that the dikes served as vents through which these were extruded. On the other hand, it is certain that no relation exists between any of the observed dikes and the basalt flows, as they differ radically in composition.

\section{THE ORE DEPOSITS.}

\section{DISTRIBUTION OF THE DEPOSITS.}

The principal iron ores of the Eagle Mountain district occur on the north limb of the dome in a chain of discontinuous deposits, $6 \frac{1}{2}$ miles long, trending about $\mathrm{N}$. $70^{\circ} \mathrm{W}$. across the summit of the range. (See Pl. I, in pocket.) They extend 3 miles west of the summit and $3 \frac{1}{2}$ miles east. The ore-bearing zone reaches in places a width of 
4,000 feet, but individual ore deposits do not exceed 500 feet in width. At the east end of the district, where the big dry wash has cut the domed area in two lengthwise, the iron ores are on the north side, on low foothills near the edge of the desert but gradually rising on the slope as they approach the summit. At the west end most of the deposits lie in the broad basin traversed by Placer Canyon. Some of them form small ridges within the basin; others lie on the slopes or along the bottom. Minor deposits are scattered along the west and southwest sides of the dome.

At the east end the lowest and easternmost deposits are at an elevation of about 1,400 feet above sea level; those at the summit are at 3,100 feet; and the lowest of the west-end deposits, at the extreme west end of the belt, are at an elevation of about 2,100 feet.

The largest deposits in the district occur in a group at the east end (Pl.IV), occupying an area along the ore-bearing zone about a mile and a half in length, with a maximum width of 1,500 feet and an average width of about 700 feet. The rocks in this area vary in strike, reaching angles of $40^{\circ}$ on either side of east and west, and dip at varying angles in a northerly direction. The deposits occur along the strike of the rocks at two horizons and are separated by a belt of quartzite, which reaches in places a width of 500 feet and is locally much altered. South of the southern (lower) ore bed is a thin-bedded schistose arkose, which rests upon a great thickness of vitreous quartzite. South of this is the lower quartz monzonite. North of the northern (upper) ore bed is a great thickness of granite containing lenses of quartzite and conglomerate and locally separated from the ore by a bed of much-altered quartzite.

The east end deposits are covered by a group of 17 claims, the Rodger No. 9, Patagonia No. 4, Rodger No. 8, Wizard, Virginia, Katie Gray, Patagonia No. 5, Rodger No. 5, Rodger No. 4, Patagonia No. 1, Patagonia No. 2, Rodger No. 2, Rodger No. 1, Iron No. 2, Iron No. 1, Patagonia No. 3, and Iron No. 5. (See Pls. I, IV, VI, IX, and X.) The claims are arranged irregularly, so that five or six of them touch the ore horizons only at their ends or corners.

In the eastern part of the group the upper ore bed is by far the largest, having a fairly regular width of outcrop of about 400 or 500 feet for a distance of 2,700 feet along the strike. Taking an average dip of $45^{\circ}$ this would give the bed a thickness of 275 to 325 feet through this extent. At the east end its width of outcrop narrows gradually to 65 feet at a point where it disappears under the outwash apron bordering the mountains. Toward the west the northern and southern ore beds unite through the pinching out of the intervening quartzite by faulting or otherwise. The northern part of the combined beds continues along the northeast side of the big dry wash, but consists largely of altered quartzite and local masses of low-grade 


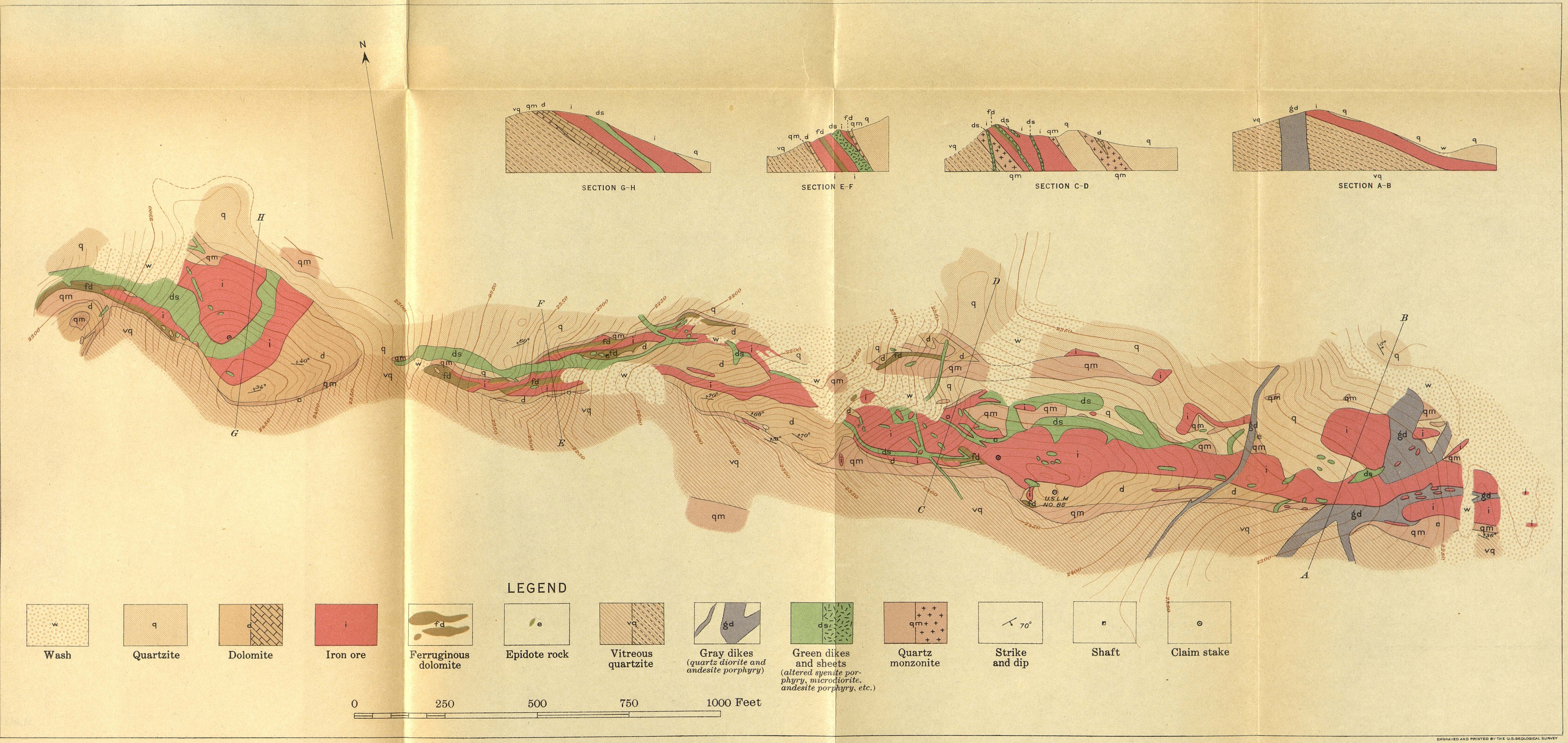

MAP AND SECTIONS SHOWING THE DISTRIBUTION AND STRUCTURE OF IRON ORE AND ASSOCIATED ROCKS ON IRON NO. 26, IRON NO. 27, AND BLACK DIAMOND NO. 8 By E. C. Harder and John L. Rich 


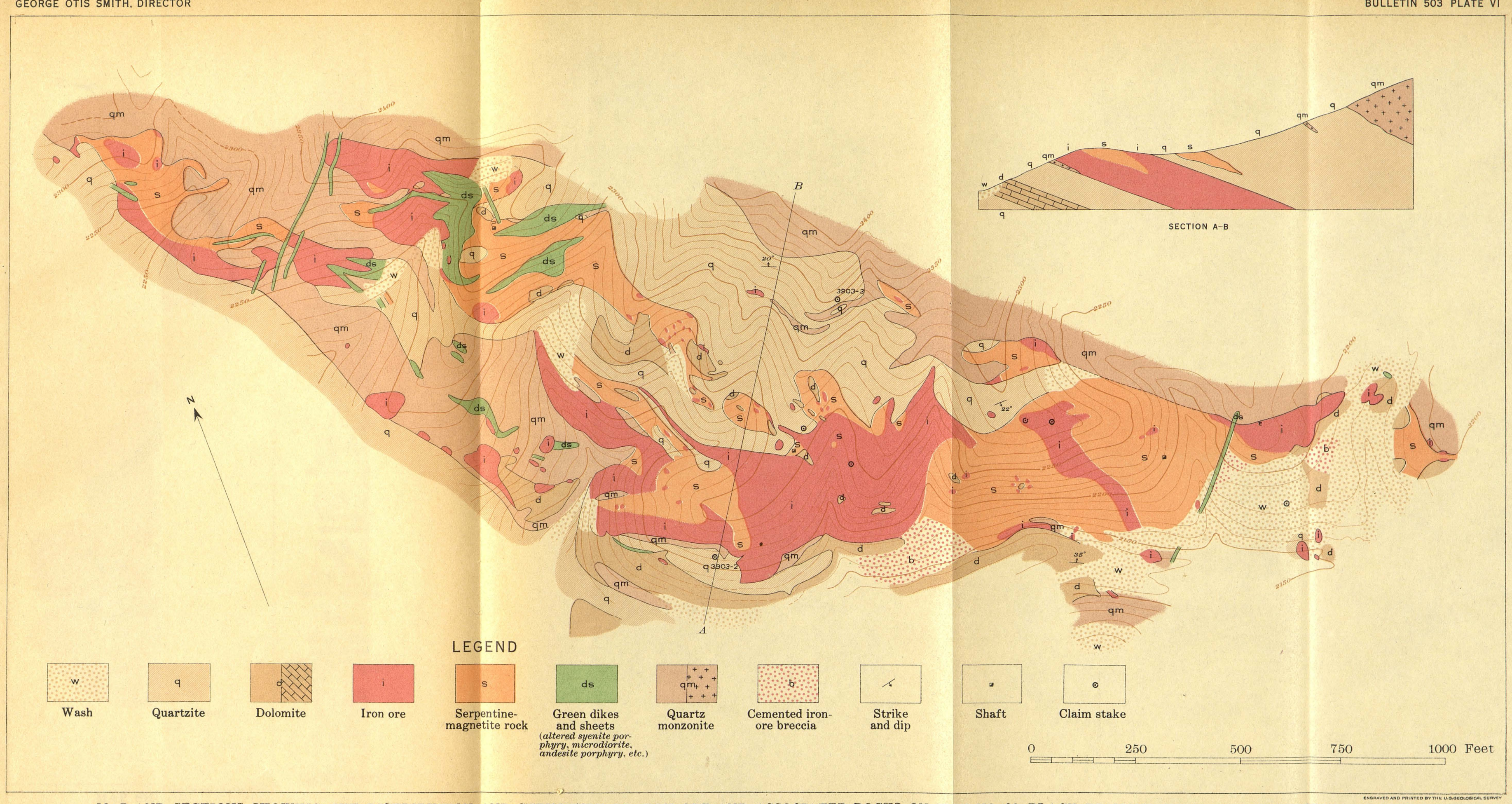

MAP AND SECTIONS SHOWING THE DISTRIBUTION AND STRUCTURE OF IRON ORE AND ASSOCIATED ROCKS ON IRON NO. 30, BLACK DIAMOND NO. 1, AND NEIGHBORING CLAIMS By E. C. Harder and John L. Rich 

ore. The southern part of the combined beds disappears for a short distance under the gravel deposits of the wash and reappears beyond the wash again separated from the northern bed. The northern ore bed continues to the mouth of Bald Eagle Gulch, beyond which it becomes very narrow and the ore appears only at intervals.

The lower ore bed is much thinner than the upper bed and its outcrop is narrower, but it is more continuous and persistent. Its outcrop ranges in width from 50 to 375 feet. Its average regular width, however, is between 75 feet and 150 feet, which, on an average dip of $30^{\circ}$, would give a thickness to the ore bed of 35 to 75 feet. Widths of outcrop greater than 150 feet are caused by irregularities of dip or by. faulting.

The lower bed is much faulted throughout the east end group of claims. In places this has caused breaks in the continuity of the outcrop, as on the Virginia and Katie Gray; elsewhere it has resulted in two parallel outcrops of the same bed, as on Rodger No. 1 and Rodger No. 2. Where Bald Eagle Gulch joins the big dry wash, the southern ore belt, here combined with the northern ore bed, disappears under gravel deposits for a distance of about 1,500 feet.

The upper ore bed does not consist of ore of uniform grade throughout its extent, though it includes large bodies of high-grade hematite. In places it contains masses of tremolite rock, muscovite-serpentine rock, and quartz monzonite, and is cut by numerous dikes of a variety of igneous rocks, which likewise cut the quartz monzonite and quartzite bounding it. Veins of a white mixture of carbonates of lime and magnesia, quartz, and serpentine are also abundant in the ore. The lower ore bed contains a more uniformly high grade of ore.

The iron-bearing zone extends westward from the east-end group of deposits to the summit of the range, a distance of about 2 miles, with a maximum width of 1,000 feet and a minimum width of 500 feet. Both the upper and the lower ore horizons continue westward as small scattered deposits through Iron No. 3, Iron No. 7, and Patagonia No. 7, but unite into one band on Iron No. 8, and as such continue westward through Iron No. 10, Syndicate No. 8, Iron No. 13, and Syndicate No. 11. Here, however, they separate again, the lower one narrow and discontinuous, the upper one wider, but also discontinuous. The lower one runs through Syndicate No. 6 and Iron No. 16, where it stops. The upper one runs through Iron No. 14, Iron No. 17, and Iron No. 18, which is on the summit.

Through this extent the ore-bearing beds consist of crystalline dolomite and iron ore and associated metamorphic minerals, bounded on the north by either quartzite and conglomerate or quartz monzonite, and on the south by schistose arkose. Where there are two bands they are separated by quartzite. In places in the quartz monzonite along the north side of the main ore-bearing zone, and 
also in the associated quartzite, there are numerous small bodies of ore, most of them veins. These are especially abundant in Iron No. 13 and Syndicate No. 7. The largest ore body between the east-end deposits and the top of the range lies just east of the summit and is about 800 feet long and 200 feet wide. The smallest deposits are mere stringers, a few inches wide.

West of the summit the ore-bearing zone continues through Iron No. 20, Iron No. 23, and Iron No. 22, extending for short distances into the Syndicate claims, which are north and south of these. The main part of the zone represents the upper ore horizon, but the lower horizon is represented at intervals in its southern portion. Another ore belt, probably at the upper ore horizon, occurs in the quartz monzonite area north of the main zone in Iron No. 40, Iron No. 41, and Syndicate No. 27, but joins it on Syndicate No. 28. West of this the ore-bearing zone disappears under stream gravels, though here and there a few outcrops occur.

The lower ore bed, corresponding to the southern ore bed of the east end, reappears at the west end of Iron No. 25, continues through Iron No. 26, Iron No. 27, and Black Diamond Nos. 8 and 45 and ends in a few scattered outcrops on Black Diamond Nos. 14 and 18. The upper ore bed reappears on Black Diamond No. 20 and Iron No. 30 and continues westward with numerous outcrops through the northern part of the Black Diamond group. The lower bed is separated from the upper by a barren area of dolomite, quartzite, and quartz monzonite, about 1,000 feet wide. For some distance west of the summit the ore beds are very irregular and discontinuous. They consist of dolomitic marble, ophicalcite, mineralized rock, an iron ore in lenses and beds in quartzite that is intruded by numerous irregular masses of quartz monzonite. West of Iron No. 25, however, the lower ore bed is continuous and regular, while the upper bed retains its irregularity through its entire extent westward from the summit.

There are two groups of big ore deposits at the west end-one on Iron No. 26, Iron No. 27, Black Diamond No. 8, and Black Diamond No. 4, and the other on Iron No. 30 and Black Diamond Nos. 20, 7, 1, 5, 3, and 4. (See Pls. V, VI, XI, XII, and XIII.) The largest single deposit in the first group is about 1,800 feet long and 50 to 150 feet wide on the outcrop. It dips to the north at angles ranging from $20^{\circ}$ to $70^{\circ}$. The largest ore body in the second group is about 600 feet long and 250 feet wide and dips $20^{\circ}$ to $30^{\circ} \mathrm{N}$.

The lower ore bed throughout most of its extent west of Iron No. 25 consists of pure, hard, crystalline hematite, without doubt the highest-grade ore in the district. The upper ore bed, on the other hand, though locally containing large bodies of pure ore, is in many places thoroughly intermixed with serpentine, mineralized rock, quartz monzonite, and dikes of igneous rocks. 


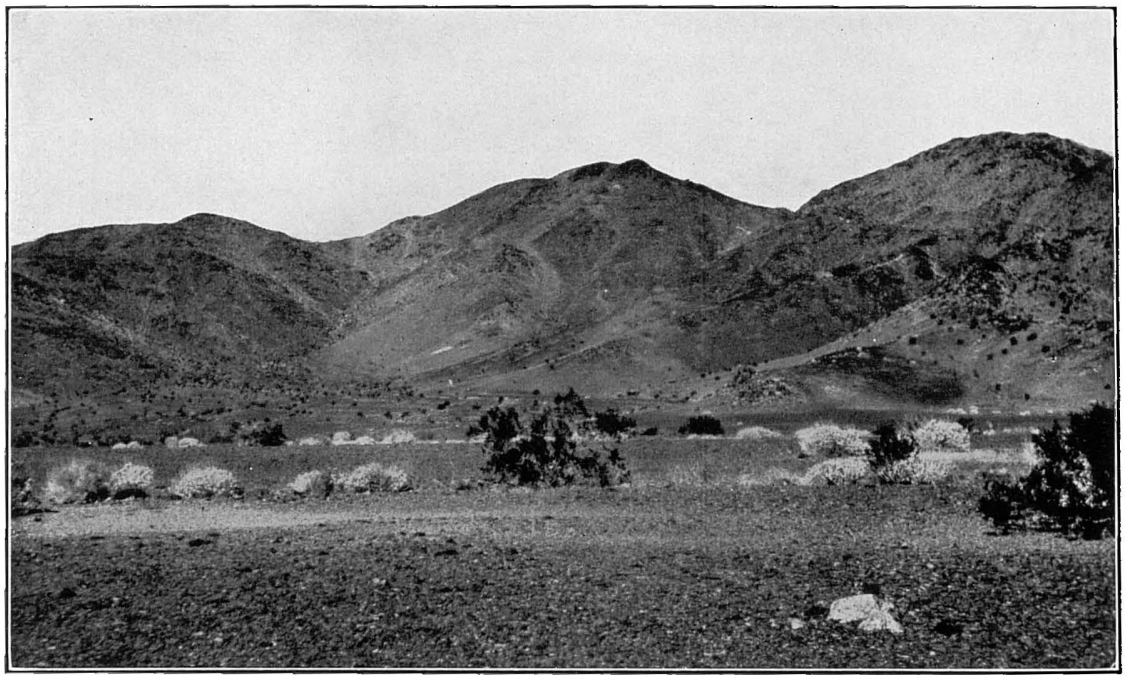

A. IRON-ORE DEPOSITS ON RODGER NO. 8, RODGER NO. 9, VIRGINIA, AND WIZARD CLAIMS. Looking west.

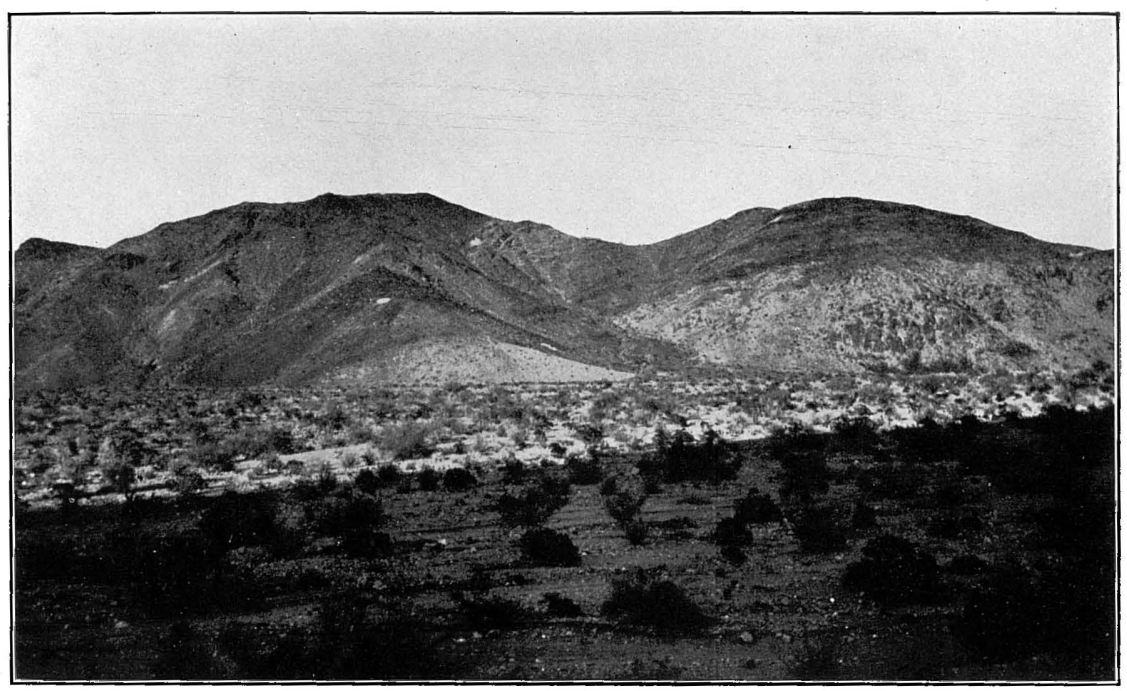

B. IRON-ORE DEPOSITS ON VIRGINIA, KATIE GRAY, RODGER NO. 8, PATAGONIA NO 5, RODGER NO. 4, AND RODGER NO. 5 CLAIMS.

Looking north. 



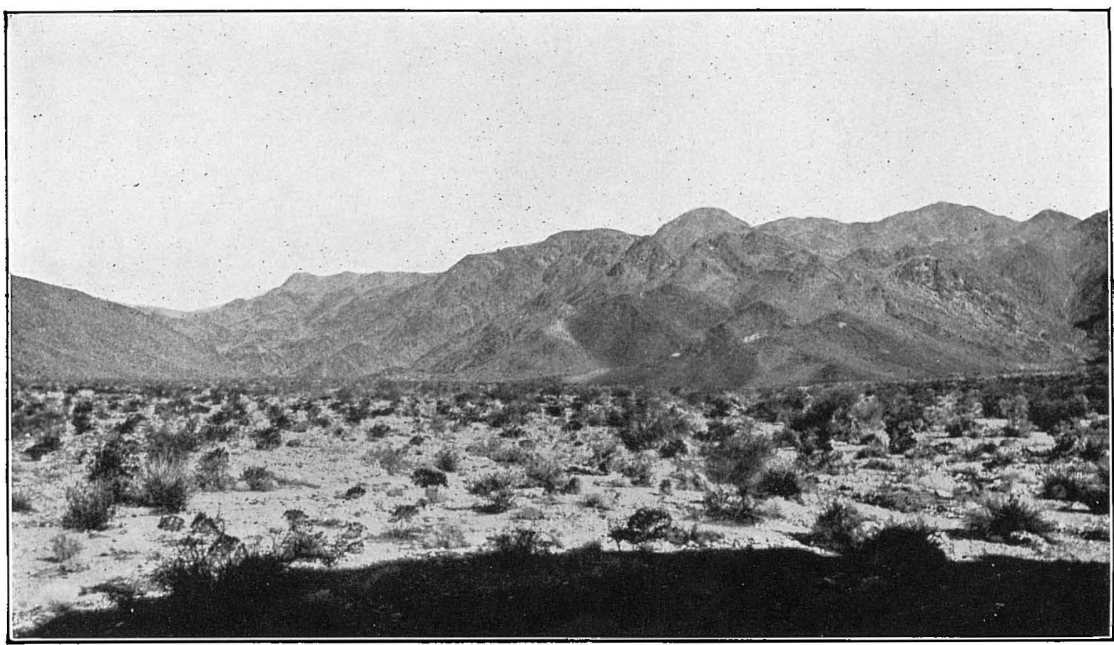

A. IRON-ORE BELT LOOKING WEST FROM KATIE GRAY CLAIM TOWARD THE SUMMIT OF THE RANGE.

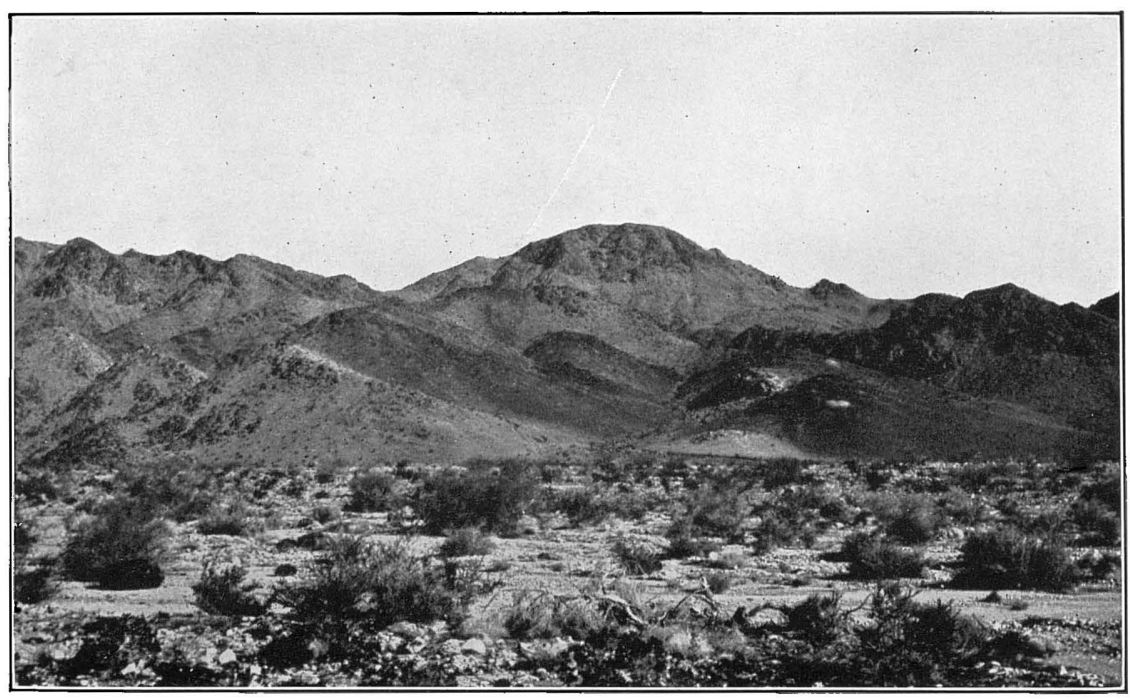

B. IRON-ORE DEPOSITS ON RODGER NO, 1, RODGER NO. 2, IRON NO, 1, IRON NO, 2, AND IRON NO. 5 CLAIMS. 



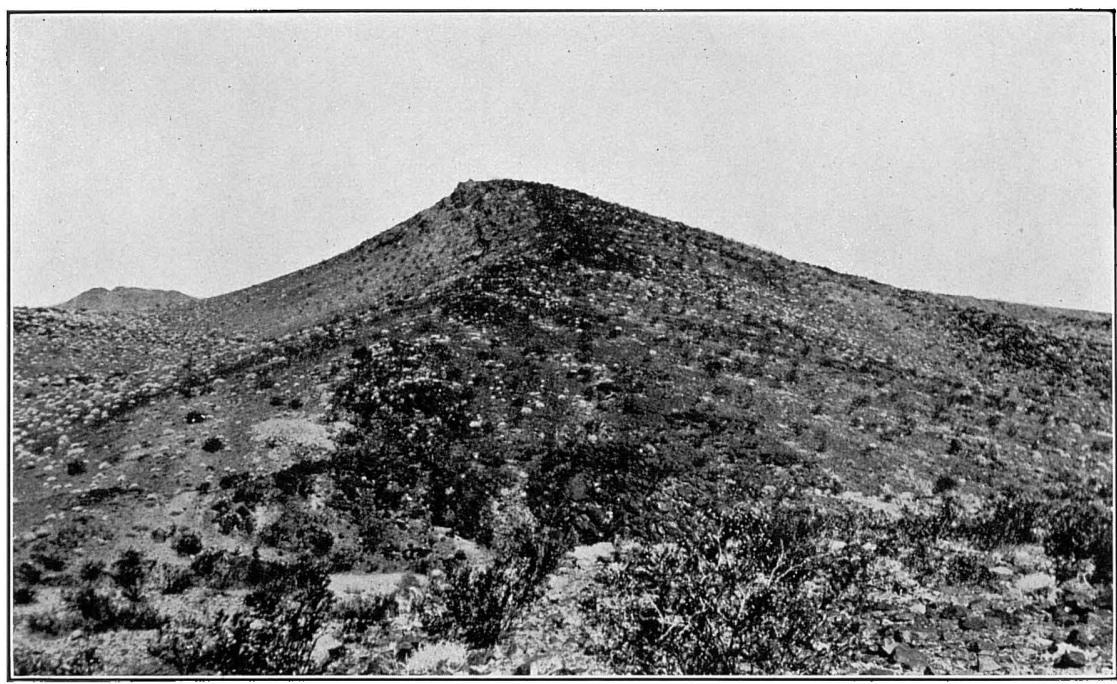

A. IRON-ORE DEPOSIT ON IRON NO. 26 CLAIM.

Looking west.

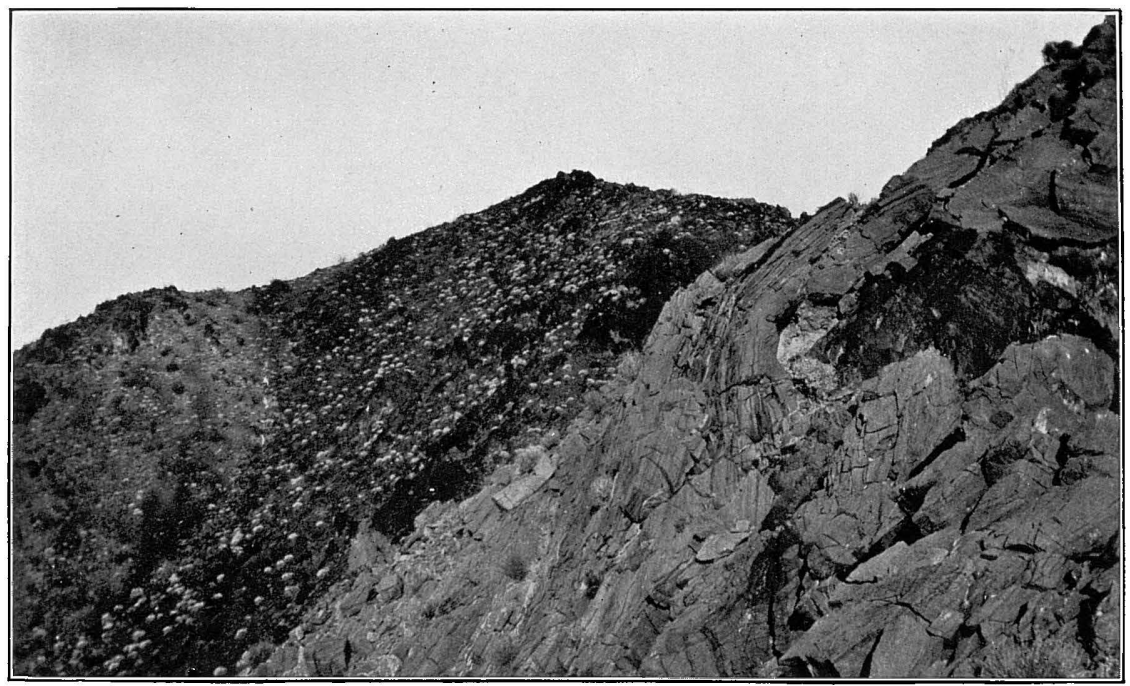

B. IRON-ORE DEPOSIT ON IRON NO. 27 CLAIM.

Looking east. 



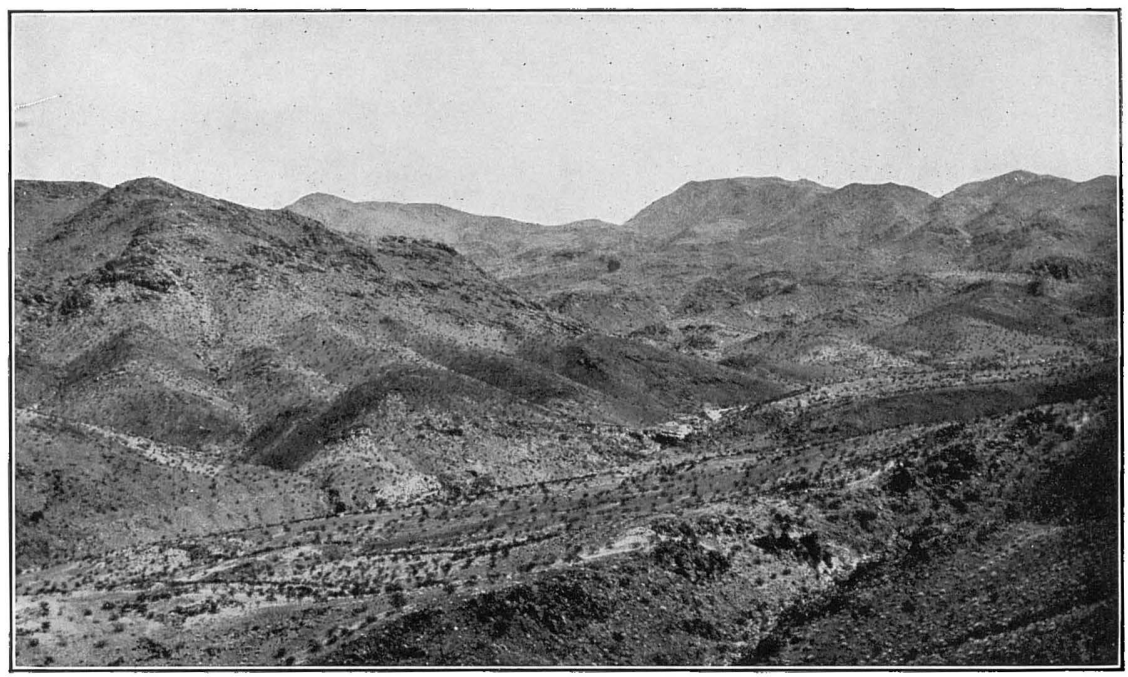

A. IRON-ORE DEPOSITS ON IRON NO, 30, BLACK DIAMOND NO. 1, AND NEIGHBORING CLAIMS.

Looking north across Placer Canyon.

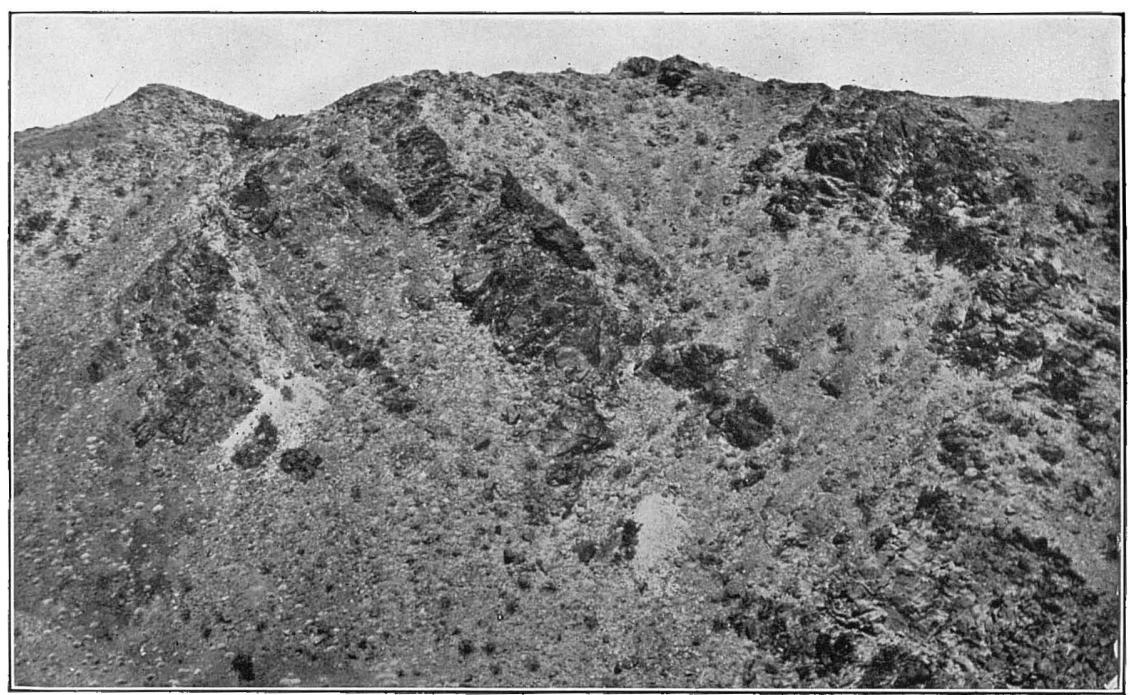

B. IRON-ORE DEPOSIT ON IRON NO. 27 CLAIM.

Looking west across ravine. 



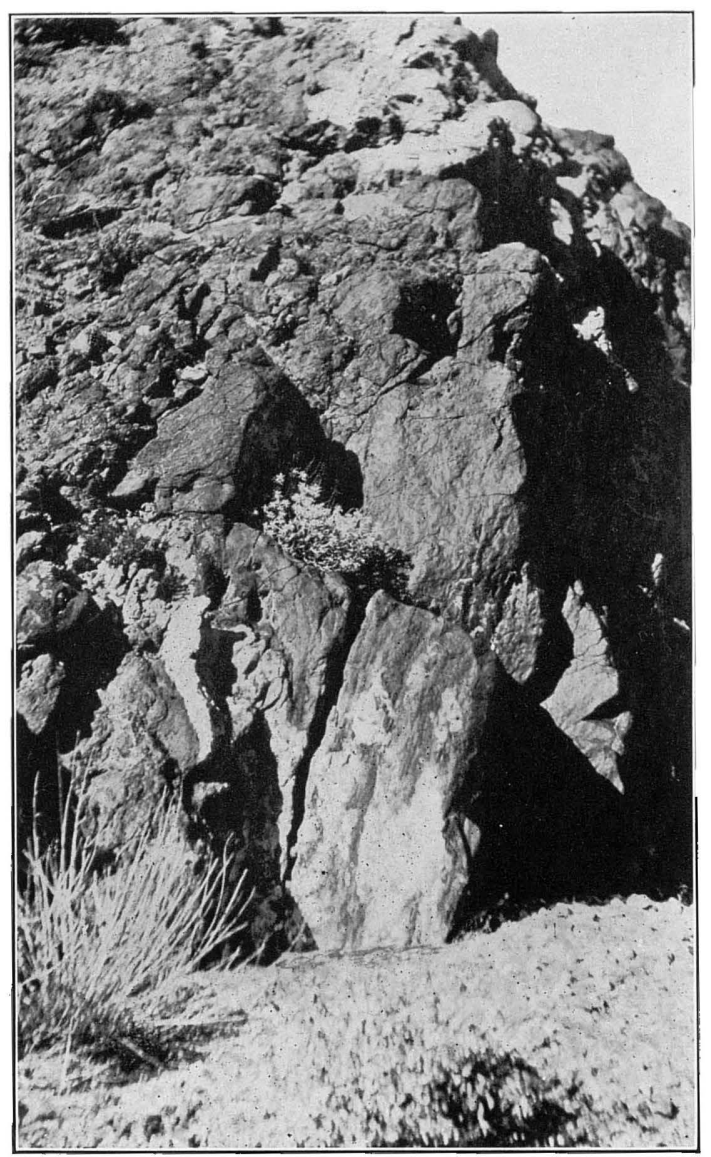

A. MIXED IRON ORE AND CRYSTALLINE DOLOMITE.

Showing structure of ore in detail.

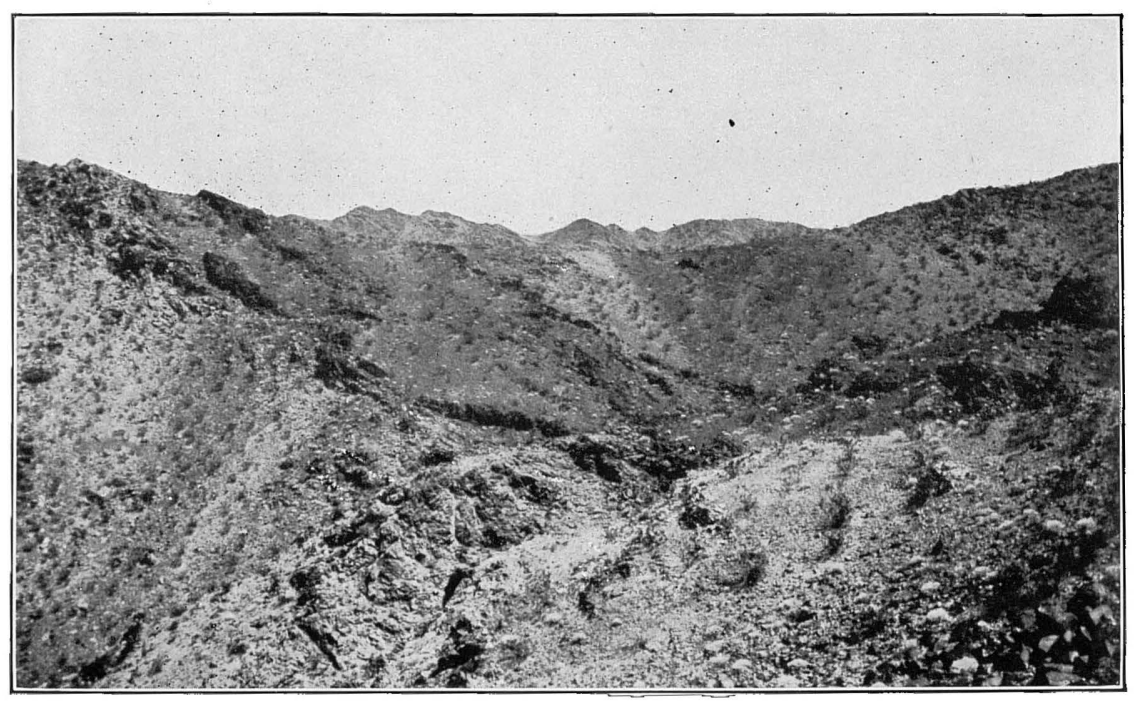

B. VIEW FROM RIDGE OF CONTACT ROCK ABOUT TWO-THIRDS OF A MILE NORTH OF IRON CHIEF MINE.

Looking east. 

A few small deposits of ore occur around the west end of the dome and in the vicinity of the Iron Chief mine, at the west end of the south limb. They are covered by the Gray Eagle and Iron Chief groups of claims. The middle and eastern parts of the south limb are almost barren of ore except for a few small unimportant masses at two or three places. Much of this area is covered by the Parker and Black Diamond groups of claims. A few small masses of ore of no importance, covered by the Superior group of claims, occur also in the outlying limestone areas west of the dome.

\section{GEOLOGIC RELATIONS AND STRUCTURE OF THE DEPONITS.}

The iron ores and associated minerals are replacements of dolomite which occurs as beds and lenses at two principal horizons in the dolomite and quartzite series. The dolomite or iron-ore lenses and beds range in width of outcrop from 5 feet to 1,000 feet, in thickness from 1 foot to 400 feet, and in length from 25 feet to more than a mile. The zone in the dolomite and quartzite series which carries dolomite and iron ore lenses and beds ranges in width of outcrop from 500 to 4,000 feet, and in thickness from 250 to 2,000 feet. It extends entirely around the oval dome except at the east end, where it is concealed under gravel deposits.

The ore-bearing zone dips away from the center of the dome at varying angles, to the north on the north $\operatorname{limb}$, to the south on the south limb, and to the west at the west end. Below it is the vitreous quartzite series with its upper schistose member just below the lower ore-bearing horizon. Above it, just above the upper ore horizon, is the upper quartz monzonite, in which there are masses of quartzite and conglomerate. Local beds of conglomerate and quartzite intervene between the upper ore horizon and the quartz monzonite.

In places, as at the east end of the north limb, the iron ore and associated minerals have replaced all the dolomite, so that they now occupy the position originally occupied by the dolomite. Elsewhere the larger portions of the dolomite beds have been replaced and crystalline dolomite occurs only in irregular masses in beds which consist largely of iron ore and gangue minerals. At still other localities the iron ore and gangue minerals occur as beds and irregular masses in a prevailingly crystalline dolomite. In most places the dolomite lenses or their altered equivalents-iron ore and metamorphic rock-occur in two main zones, which are separated by a varying thickness of fine-grained quartzite. Locally, however, the two beds unite into one, by the thinning or pinching out of the intervening quartzite. Elsewhere small lenses of dolomite or ore may occur also at different horizons within the quartzite between the two main beds.

In a general way the zone which now carries the iron ores consisted before metamorphism of dolomite and sandstone. Over most of the 
area the sandstone was predominant, and the dolomite occurred in it as beds and lenses. Locally, however, the dolomite was the predominant formation. During the metamorphism the dolomite and sandstone were first recrystallized and consolidated into dolomitic marble and quartzite, and later much of the dolomite and some of the quartzite was replaced by iron ore and an abundance of gangue minerals-contact rock, mineralized rock, and metamorphic rock-was formed in both. So at present the ore-bearing zone consists of fresh or altered quartzite, fresh or altered crystalline dolomite, and iron ore with an abundance of associated metamorphic gangue minerals.

Nearly all the important iron-ore deposits were developed along the dolomite beds. Where these were impure or contained quartzite layers the gangue minerals are much more abundant than the ore, and locally for considerable stretches little or no ore occurs in association with them. Where the dolomite was presumably pure, the iron ore contains little or no gangue material. In places the quartzite between the dolomite or ore lenses is also considerably altered, metamorphic minerals being developed abundantly and, locally also, small veins and replacements of iron ore. At one or two places small bodies of ore and contact rock occur in the schistose arkose below the dolomite and quartzite series. (See p. 34.)

The contact between the lower ore-bearing beds and the schistose sandstone beds below is generally sharp or well defined. In many places it is marked by a thin sill of quartz-feldspar rock. The upper iron-bearing horizon is usually bounded above by the upper quartz monzonite intrusion. In many places the dolomite or iron ore and gangue minerals come in direct contact with quartz monzonite; in others they are separated from it by a small thickness of much altered quartzite. In the north-central part of the area the quartz monzonite near the ore belt carries numerous small and large veins of iron ore close to the contact for a distance of nearly a mile.

The iron ore deposits are cut abundantly by dikes and sheets of igneous rock and locally contain veins of white calcareous material. All the dikes noted were apparently later than the ore and cut across the deposits indiscriminately. They seem, however, to have produced little or no change in the character of the ore with which they came in contact. The white veins range from less than an inch to a foot or more in thickness, and some of the larger ones are several hundred feet long. Unlike the dikes, they are apparently confined to the ore deposits, not being found in the surrounding rocks. They are clearly fissure fillings and generally have ore in both walls, though in places they occur on the contact of the ore and the dikes. They consist largely of carbonates of lime and magnesia, but contain small quantities of quartz, serpentine, and iron oxide. The iron oxide and serpentine were derived from the surrounding ore, being either present 
as included fragments or recrystallized and deposited along with the other minerals. Some parts of the veins consist mostly of massive carbonate; other parts consist of parallel crystalline bands of the various minerals. In the latter also the carbonate predominates. The quartz is in aggregates of small crystals and is not chalcedonic. It was apparently deposited last, as it fills elongated cavities and is surrounded by carbonates. Bands of quartz alternate with bands of iron oxide locally where the latter is recrystallized, and in some places a little carbonate is interbanded with them. The serpentine is in granular masses or fibrous radial aggregates, having been included during the vein deposition. The carbonates are apparently a mixture of calcite and dolomite, but it is possible that magnesite also occurs with them.

\section{NATURE OF THE DEPOSITS.}

Five types of deposits.-The iron-ore deposits of the district may be grouped into five types-(1) beds and irregular masses of hematite and magnetite, generally inclosed between quartzite beds or between quartzite and quartz monzonite, and generally of large extent, associated with an abundance of gangue minerals and here and there containing masses of partly replaced or unreplaced crystalline dolomite and quartzite; (2) layers of hematite in crystalline dolomite beds and lenses, lying approximately parallel to the stratification of the dolomite and having great lateral extent compared with their thickness and exhibiting sharp contact with the inclosing dolomite; (3) small replacement deposits in sediments directly at the contact of minor quartz monzonite intrusions; (4) veins in quartzite; (5) veins in quartz monzonite.

First type.-The deposits of the first type are by far the most abundant, probably including more than 80 per cent of the ore in the district. All except one or two of the deposits along the upper ore horizon are of this type, as are also all the deposits along the eastern part of the lower ore horizon. These deposits represent complete, or nearly complete, replacements of original impure dolomite. The calcium carbonate has been replaced by iron ore, whereas the silicates present were either simply recrystallized or metamorphosed into other minerals.

The deposits of this type which occur at the upper ore horizon are generally bounded below by quartzite and above by quartz monzonite. Locally, especially in the eastern part of the district, they are bounded above for considerable distances by green dikes and sheets. Those at the lower ore horizon are bounded above by quartzite and below by schistose arkose or by thin sheets of the quartzfeldspar rock phase of the quartz monzonite. Locally along both horizons they are entirely inclosed within the associated gangue rock and do not come in contact with any of the inclosing formations. 
The distribution of iron ore and gangue rock is irregular. In places the ore beds consist entirely of pure solid ore; in others they consist of gangue rock with iron oxides only in disseminated specks. Between these two extremes there are all gradations; some irregular masses of pure ore occur in prevailing contact rock; some masses of contact rock occur in an otherwise pure ore bed.

The most common of the contact phases associated with the ore deposits are ferruginous dolomite, mica-serpentine rock, serpentinemagnetite rock, and tremolite-magnetite rock. These phases are widely and irregularly distributed through the district, but in general the tremolite-magnetite rock and mica-serpentine rock are more abundant in the eastern part and the serpentine-magnetite rock in the western part.

Most of the ore bodies consist of compact to coarsely crystalline hematite, but large masses or small irregular bodies of magnetite occur here and there within them. Where gangue minerals, especially serpentine, are abundant, magnetite is predominant, and where large masses of pure ore occur they consist largely of hematite.

Second type.-The iron-ore layers occurring in dolomitic marble generally consist of hematite, varying in texture from compact granular to coarsely crystalline. They range in thickness from less than an inch to 75 feet or more and the longest have a length of several thousand feet. The layers are, as a rule, approximately parallel to the bedding of the inclosing rocks. They may be bounded both above and below by crystalline dolomite or they may be bounded by crystalline dolomite on one side and either quartzite or quartz monzonite on the other side.

In most of the deposits of this type gangue minerals occur very sparingly, and where they do occur they are generally in separate masses distinct from the ore masses, which as a rule are pure.

The contact between the ore and the crystalline dolomite is sharp, but in places the dolomite near the contact contains disseminated specks of iron ore and the iron ore contains scattered dolomite specks. Such a gradation locally extends as far as an irch on either side of the contact, but elsewhere it may extend less than one-tenth of an inch.

Layered deposits in crystalline dolomite occur on Iron Nos. 17, 18, 20, 23, 26, and 27 and Black Diamond Nos. 8 and 45.

Third type.-Replacement bodies of small dimensions are found abundantly at the contact of minor intrusive quartz monzonite masses in the sediments. They occur more commonly where the rock intruded is dolomite, but are also found in the impurequartzite. In some places the ore almost entirely surrounds the intrusive masses; but at a few places along the contact and around the rest of the mass the quartz monzonite is in direct contact with the sediments. 
The ore bodies in some places consist entirely of pure ore; in others of interlayered ore and sediments or contact rock. The replacement by the ore has been selective, as in the other types of replacement deposits; certain portions of the sediments are replaced and others left unaltered, or only partly altered.

Fourth type.-Veins of iron ore in quartzite are not very abundant, their typical occurrence being on Iron No. 10, in the quartzite north of the upper iron ore horizon. The veins are generally narrow, being small fissure fillings in the quartzite and partial replacement of the fissure walls.

Fifth type.-Veins of iron ore in quartz monzonite are somewhat more abundant than those in quartzite, but do not constitute an important type of deposits. Their typical occurrence is in the upper quartz monzonite masses just north of the iron-bearing belt on Iron Nos. 13, 14, and 17 and Syndicate No. 7.

They are generally small, some being veins and some irregular masses. They were formed as fissure fillings and partial replacement in the quartz monzonite.

\section{CHARACTER AND GRADE OF THE ORE.}

The ore is largely hematite; subordinately magnetite. Limonite or goethite occurs in a few places. There is apparently no definite relation between the hematite and the magnetite as regards distribution, the magnetite occurring abundantly in some places while elsewhere it is almost absent. It may occur in large bodies with little or no hematite, or it may be disseminated through hematite masses in small specks and grains.

The hematite is dark red and ranges in texture from coarsely crystalline to finely granular. All the crystalline ore and most of the granular ore is very hard, but local pockets of soft granular ore have been encountered underground, as in the tunnel on the Wizard, suggesting that with depth a greater proportion of the ore may be soft. In other places, however, pits have been sunk into hard ore to a depth of 15 or 20 feet without encountering soft ore. With the small amount of exploratory work done up to the present it is impossible to make conjectures as to whether a general change in the character of the ore may be expected with depth. Indications are that the distribution of soft ore is local. The magnetite is usually hard and granular, but in places where large masses of it are found some of it is coarsely crystalline and when broken presents shiny black surfaces.

The purest masses of iron ore consist in most places of hematite; the impure ore masses in which there is much serpentine and a gangue of metamorphic minerals contain a large percentage of magnetite. The ore occurring along the white carbonate veins consists largely of magnetite. Local masses of pure, high-grade magnetite are found, 
however, with little or no gangue material, but such occurrences are not abundant.

The hydrated oxides of iron are rare. Thin films occur in places as a coating on the other ores, being formed from these by hydration. On Iron No. 30 hydrated oxides are formed in rounded masses with dense texture and conchoidal fracture embedded in ore masses consisting largely of hematite and magnetite.

Although crystalline structure is characteristic of most of the ores, well-developed crystal forms are not abundant. Locally, however, they line cavities in ore masses or associated rocks or are disseminated through metamorphic mineral masses or unreplaced rock. The crystal forms found suggest that pyrite and magnetite were the original minerals. Both, however, are usually altered to hematite, though the pyrite is sometimes altered to limonite. Of the pyrite forms striated cubes are most abundant, many of these being modified by the octahedrons. Rarely perfect octahedrons occur modified by the pyritohedron. The characteristic magnetite form is the dodecahedron without modification. The magnetite and pyrite crystal forms are intimately intermixed and were evidently deposited simultaneously. The pyrite forms are somewhat more abundant than the magnetite forms.

The hematite is apparently for the most part secondary after pyrite and magnetite. One small body of coarsely crystalline specular hematite, originally deposited as such, occurs on the Superior group of claims, in the outlying limestone areas, several miles west of the domical area. With the exception of this mass, however, none of the hematite can be said to be undoubtedly original.

A large proportion of the ore is intermixed with metamorphosed rock and must be concentrated before it can be used in the blast furnace. This is true of probably more than half of the bulk of the ore-bearing beds. A large amount of pure ore, however, which can be shipped directly to the furnaces, occurs in parts of the district. The distribution of the pure ore in the ore-bearing rock is irregular. In some places large bodies of it contain small masses of gangue material; in other places small bodies of pure ore are distributed through ore-bearing rock. The ore-bearing gangue material consists of the various phases of altered dolomite and quartzite, changed by metamorphism to mica, amphibole, pyroxene, serpentine, and other minerals.

The ore itself is of high grade, containing a large percentage of metallic iron and a small percentage of phosphorus. None of the impurities are present in sufficient amount to be injurious.

In the following table is given average analyses, by Dickman and Mackenzie, of the ore from all the principal ore bodies in the district. The samples were taken from surface outcrops, being collected at 
intervals across the ore bodies along regularly spaced lines. These analyses were kindly furnished the writer by Mr. R. N. Dickman and Mr. H. P. Wherry and are published with the consent of the Iron Chief Mining Co.

Average analyses of Eagle Mountain iron ores.

\begin{tabular}{|c|c|c|c|c|c|c|c|c|}
\hline & 1 & 2 & 3 & 4 & 5 & 6 & 7 & 8 \\
\hline 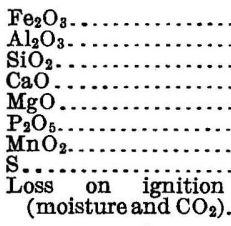 & $\begin{array}{l}89.30 \\
.16 \\
6.70 \\
1.00 \\
1.83 \\
.10 \\
.27 \\
.038 \\
.50\end{array}$ & $\begin{array}{l}91.43 \\
.20 \\
3.30 \\
1.04 \\
2.16 \\
.114 \\
.27 \\
.06 \\
1.20\end{array}$ & $\begin{array}{l}92.00 \\
.24 \\
4.20 \\
.65 \\
.50 \\
.132 \\
.090 \\
.118 \\
1.90 .\end{array}$ & $\begin{array}{l}94.43 \\
.36 \\
2.80 \\
.40 \\
.20 \\
.112 \\
.12 \\
.115 \\
1.50\end{array}$ & $\begin{array}{c}92.57 \\
.66 \\
4.20 \\
.40 \\
.38 \\
.121 \\
.19 \\
.103 \\
1.20\end{array}$ & $\begin{array}{c}93.74 \\
.24 \\
3.40 \\
.65 \\
.28 \\
.094 \\
.20 \\
.136 \\
1.10\end{array}$ & $\begin{array}{r}93.22 \\
.54 \\
4.00 \\
.50 \\
.20 \\
.130 \\
.08 \\
.163 \\
1.10\end{array}$ & $\begin{array}{c}94.28 \\
.32 \\
2.90 \\
.55 \\
.28 \\
.114 \\
.09 \\
.145 \\
1.20\end{array}$ \\
\hline \multirow{3}{*}{$\begin{array}{l}\mathrm{F}(\ldots \ldots \ldots \\
\mathrm{M} \\
\mathrm{M} \\
\mathbf{M}\end{array}$} & 99.898 & 99.774 & 99.830 & 100.037 & 99.824 & 99.840 & 99.933 & 99.879 \\
\hline & $\begin{array}{l}62.50 \\
.044 \\
.18\end{array}$ & $\begin{array}{l}64.00 \\
.051 \\
.18\end{array}$ & $\begin{array}{l}64.40 \\
.058 \\
.06\end{array}$ & $\begin{array}{l}66.10 \\
.049 \\
.08\end{array}$ & $\begin{array}{l}64.80 \\
.053 \\
.12\end{array}$ & $\begin{array}{l}65.62 \\
.041 \\
.13\end{array}$ & $\begin{array}{l}65.26 \\
.057 \\
.05\end{array}$ & $\begin{array}{r}66.00 \\
.50 \\
.06\end{array}$ \\
\hline & 9 & 10 & 11 & 12 & 13 & 14 & 15 & 16 \\
\hline 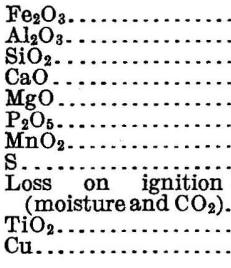 & $\begin{array}{r}94.11 \\
.41 \\
3.00 \\
.40 \\
.30 \\
.116 \\
\text { Trace. } \\
.105 \\
1.50\end{array}$ & $\begin{array}{l}94.52 \\
.25 \\
3.10 \\
.35 \\
.20 \\
.089 \\
.09 \\
.110 \\
1.10\end{array}$ & $\begin{array}{r}95.42 \\
.36 \\
2.00 \\
.30 \\
.36 \\
.091 \\
\text { Trace. } \\
.148 \\
1.26\end{array}$ & $\begin{array}{r}94.42 \\
.45 \\
2.80 \\
.40 \\
.28 \\
.121 \\
.08 \\
.214 \\
\\
1.20\end{array}$ & $\begin{array}{r}94.45 \\
.50 \\
2.70 \\
.25 \\
.28 \\
.066 \\
\text { None. } \\
.143 \\
1.40\end{array}$ & $\begin{array}{r}95.71 \\
.25 \\
2.10 \\
.30 \\
.20 \\
.064 \\
\text { None. } \\
.088 \\
1.20\end{array}$ & $\begin{array}{c}93.43 \\
.29 \\
3.25 \\
.35 \\
.30 \\
.128 \\
.09 \\
.169 \\
1.80\end{array}$ & $\begin{array}{c}96.15 \\
.20 \\
1.80 \\
.80 \\
.20 \\
.103 \\
.12 \\
.083 \\
.50 \\
\text { None. } \\
\text { None. }\end{array}$ \\
\hline & 99.941 & 99.809 & 99.969 & 99.965 & 99. 789 & 99.912 & 99.807 & 99.956 \\
\hline 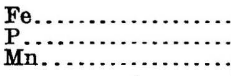 & $\begin{array}{l}65.88 \\
.051 \\
\text { Trace. }\end{array}$ & $\begin{array}{l}66.17 \\
.039 \\
.06\end{array}$ & $\begin{array}{l}66.82 \\
.040 \\
\text { Trace. }\end{array}$ & $\begin{array}{l}66.10 \\
.053 \\
.05\end{array}$ & $\begin{array}{l}66.12 \\
.029 \\
\text { None. }\end{array}$ & $\begin{array}{l}67.00 \\
.028 \\
\text { None. }\end{array}$ & $\begin{array}{l}65.40 \\
.055 \\
.06\end{array}$ & $\begin{array}{l}67.31 \\
.045 \\
.083\end{array}$ \\
\hline
\end{tabular}

1. A verage of samples from scattered iron ore deposits on Gray Eagle group of claims surrounding the Iron Chief mine. (Gray Eagle Nos. 5, 3, and 4; Eagle; Eagle Age; Iron Chief No. 1; and Syndicate Nos. 29 and 30 .)

2. Average of samples from scattered iron ore deposits in the western part of the Black Diamond group. (Black Diamond Nos. 11,13,9,10,18,14, 25,1, 2,3, and 5 and West End.)

3. Average of samples from large iron ore deposit on Iron No. 30 and neighboring claims. (Iron No. 30 and Black Diamond Nos. 1 and 20 .)

4. A verage of samples from long iron ore bed along Black Diamond Nos. 8 and 45 and Iron Nos. 27 and 26.

5. Average of samples from scattered iron ore deposits on Black Diamond No.42, Syndicate Nos. 28 and 27 , and Iron No. 22

6. Average of samples from scattered iron ore deposits on Iron Nos. 41, 40, 20, 23, and 22 and Syndicate No. 28.

7. Average of samples from scattered iron ore deposits just west of the summit. (Iron Nos. 20 and 18 and Syndicate No. 12.)

8. Average of samples from large iron ore deposits just east of the summit. (Iron Nos. 18 and 17.)

9. Average of samples from scattered iron ore deposits on Iron Nos. 17, 16, and 14 and Syndicate No. 6.

10. Average of samples from belt of scattered iron ore deposits along Iron Nos. 13, 10, 8, 7,5, and 3; Syndicate No. 8; and Patagonia No. 7.

11. Average of samples from large iron ore deposits on Iron Nos. 5, 2, and 1 and Rodger Nos. 2 and 1.

12. Average of samples from large deposits along northern iron ore horizon at east end on Rodger Nos. 4,5, and 8.

13. Average of samples from southern iron ore horizon at east end on Rodger No. 5, Patagonia No. 5, Katie Gray, and Virginia.

14: Average of samples from southern iron ore horizon at east end on Virginia and Wizard.

15. Average of samples from northern iron ore horizon at east end on Rodger Nos. 8 and 9 and Patagonia No. 4.

16. Average of samples from Rodger No. 1 and Iron Nos. 2, 5, 10, 13, 14, and 17. $19557^{\circ}-$ Bull. $503-12-5$ 
These average analyses show that the percentage of iron oxide in the ores ranges from 89.3 to 95.71 , giving a corresponding metallic iron content of 62.5 to 67 per cent. Rarely samples may run as low as 54 per cent or as high as 68.6, but the average run of analyses is between 64 and 67 per cent. For comparison it may be noted that the ore mined in the Lake Superior district at present averages about 58 per cent metallic iron.

The average range of phosphorus is between 0.028 and 0.058 per cent, thus making practically all the ore of Bessemer grade. Rarely, however, samples are obtained in which the phosphorus runs as high as 0.21 per cent or as low as 0.01 per cent. (See fig. 4.)

The content of silica ranges between 2 and 6.7 per cent, which appears to be very low when it is remembered that even the calcareous Clinton ores of the Birmingham district generally contain more than 7 per cent silica. Lime ranges from 0.25 to 1.04 per cent and magnesia from 0.2 to 2.16 per cent. Silica, magnesia, and lime will increase with the increase of gangue minerals, which are mostly silicates. Increase of these constituents will mean a proportional decrease in the metallic iron content.

Sulphur ranges from 0.038 to 0.214 per cent.

The manganese content is negligible, and copper and titanic oxide were absent altogether in the one sample which was examined for them (No. 16).

\section{ESTIMATES OF QUANTITY OF ORE.}

The largest single deposit of ore and associated gangue minerals in the district occurs along the upper ore horizon in the east end group of deposits. This ore body is exposed discontinuously for a distance of nearly 6,000 feet. It has a maximum width of outcrop of about 500 feet and a maximum thickness of about 325 feet. It. dips to the north at angles ranging from $30^{\circ}$ to $55^{\circ}$. On the supposition that the body extends down the dip 300 feet from the center of the outcrop it would contain nearly $40,000,000$ tons of mixed ore and gangue material. A rough estimate would make less than one-third of this gangue material.

Similar calculations, based on the best available information concerning the structure, have been made with regard to all the other large deposits in the district. The extent of the ore bodies beneath the surface can, of course, be judged only from structure and from the surface outcrops. The greatest vertical distance through which any of the ore bodies are exposed is 350 feet, and from this it may be judged that most of the large ore bodies extend at least 300 or 400 feet down the dip. It is likely, however, that the deposits may extend many times as far; indeed, judging from the longitudinal extent of the ore-bearing beds, it is more than likely. 


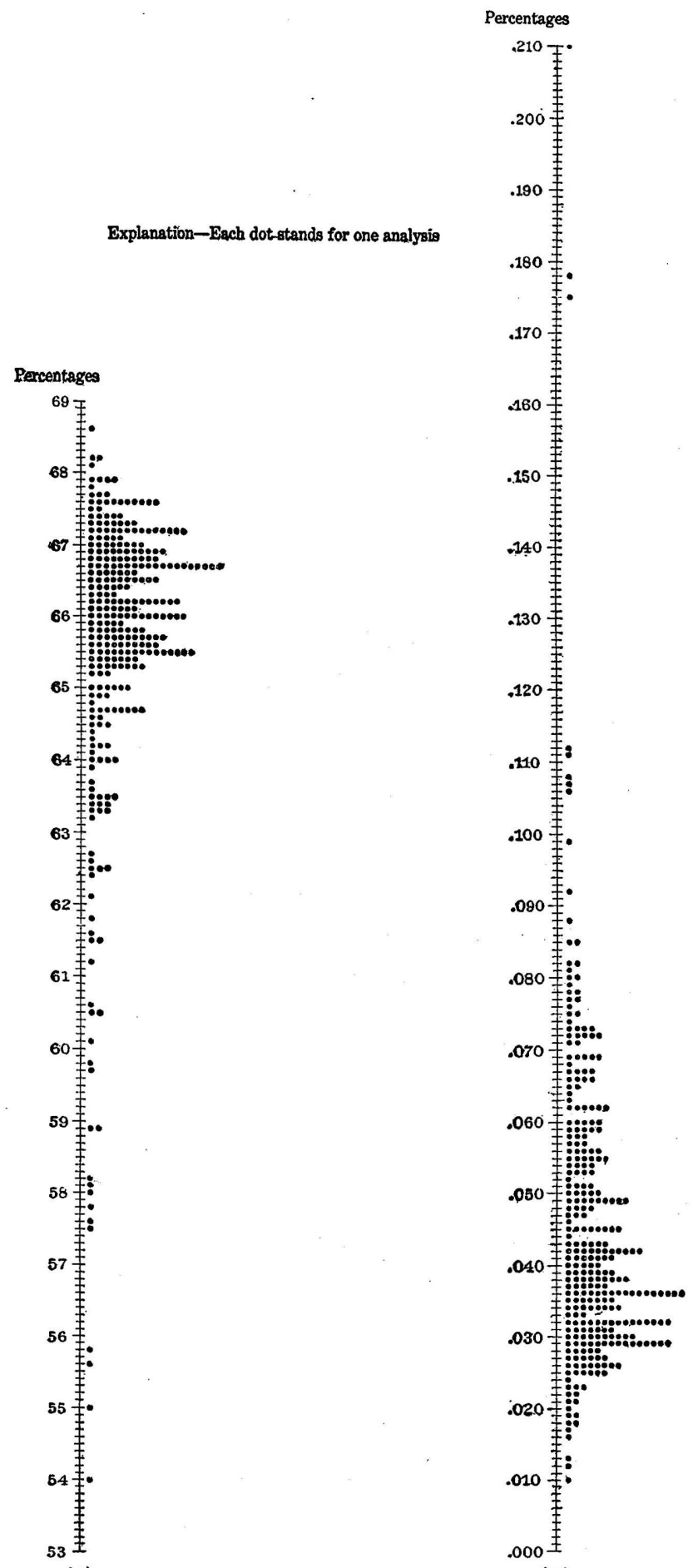

(A)

(B)

FiguRe 4.-Diagram showing iron (A) and phosphorus (B) content of Eagle Mountain iron ores. 
A moderate estimate of the total quantity of mixed ore and gangue material available in the deposits now exposed, assuming that they extend several hundred feet down the dip (the exact depth taken varying with the size of the deposits), is about $75,000,000$ tons. Of this quantity probably less than one-fifth may be assumed to be gangue material and the rest ore, most of it of very high grade. This estimate does not include large quantities of contact rock that contain a variable percentage of magnetite and hematite. It should also be remembered that the estimate may be greatly increased if it is assumed that the ore-bearing beds continue farther down the dip.

\section{DEVELOPMENT AND COMMERCIAL IMPORTANCE.}

No iron ore has been mined in the district, and except at the Iron Chief mine only enough work has been done to meet the requirements for patent. All the principal deposits of the district belong to the Iron Chief Mining Co.

About 100 pits, shafts, and tunnels have been sunk in development and assessment work on the iron ores. This number does not include the workings of the Iron Chief gold mine, in which considerable quantities of magnetite were encountered. The longest tunnel is 124 feet long; the deepest shaft is 18 feet deep. The greatest depth reached beneath the surface is at the end of the longest tunnel (on Rodger No. 2), a distance of about 42 feet below the surface. No diamond drills have been used in the district. A great many of the workings are along contacts of ore and dolomite or mineralized rock and are an aid in defining the ore bodies, as well as in showing the effects of metamorphism and the geologic relations in general. The most important workings are in the Wizard, Rodger No. 8, Katie Gray, Rodger No. 5, Rodger No. 2, Iron No. 2, Iron No. 26, Iron No. 27, and Iron No. 30.

The Iron Chief mine is on the Gray Eagle claim, one of the Gray Eagle group. It consists of one main shaft with drifts at two levels, both of which communicate with the surface by tunnels. Several stopes and chambers have been excavated at points where shoots of gold ore were found. A stamp mill, with settling vats, was built on the slope just north of the main shaft. Considerable gold was taken from the mine, but the ore eventually became too scattered and lean to pay for operations. Water was obtained from Cottonwood Springs through a pipe line.

At present there is no way of utilizing the iron ore of the district. It is far from transportation lines, and even if a railroad were built to the deposits the cost of transportation to the nearest furnaces would eat up the profit. It is beyond doubt, however, that before long blast furnaces and steel plants will be established at points in southern California, as they are now being established on Puget Sound, and in 
this event the Eagle Mountain ores will probably be among the first to be utilized.

A large quantity of high-grade Bessemer ore is in sight, besides a large quantity of impure ore that must be concentrated mechanically before it can be used in the blast furnace. Judging from the preceding estimates, enough high-grade ore is in sight to supply a modern blast furnace of a daily capacity of 500 tons of pig iron for more than 200 years.

Limestone and dolomite available for flux, though not especially abundant in the southern part of California, occur at numerous scattered localities in Mohave and Colorado deserts and in the San Bernardino Mountains. The dolomite of the Eagle Mountains associated with the iron ores might be utilized for flux to some extent, but the abundant association with them of ophicalcite and silicate rock makes a large percentage of it unsuitable for smelting operations.

The absence of fuel is the principal obstacle to the establishment of the iron industry in southern California. The nearest deposits of coking coal are in Colorado, the lignites and bituminous coals of Washington and Oregon being unsuitable for this purpose. It seems likely, however, that before many years pass extensive mining operations will be started in the Alaskan coal fields. In this event large quantities of coking coal will be shipped from Alaska to Pacific coast ports and will afford a means of establishing blast furnaces and steel plants.

\section{METAMORPHISM AND ORE FORMATION.}

\section{PERIODS OF METAMORPHISM.}

The rock formations of the Eagle Mountain district indicate that metamorphism occurred at three different stages in the geologic history of the region-first, before the deposition of the vitreousquartzite series and dolomite-quartzite series, affecting only the older rocks; second, during the intrusion of the quartz monzonite into the later sediments; and, third, soon after the intrusion of the quartz monzonite.

The earlier metamorphism was regional, affecting a large area in southern California, and probably in Nevada and Arizona. The old sediments were altered to schist, quartzite, and marble and the igneous rocks to schist and gneiss. The second metamorphism was due to heat and pressure accompanying the intrusion of the quartz monzonite. It affected only the rocks in the regions in which these intrusions occur, altering the later sediments to quartzite, schist, marble, ophicalcite, and silicated marble and locally forming various metamorphic minerals along the contact. The third metamorphism 
was due to the action of ore-bearing solutions coming after the quartz monzonite intrusions. By it marble and ophicalcite, and to a less extent quartzite, were locally replaced by iron ore and associated metamorphic minerals. It is possible that further metamorphism occurred during the intrusion of the various later dikes and sheets, but this metamorphism can not be distinguished from that occurring at the other stages. The various metamorphic rock types have been discussed in connection with the descriptions of the rocks and ore deposits, and it is the object of these paragraphs simply to bring together briefly all the facts concerning the different stages of metamorphism and to enlarge upon the effects of the metamorphism by ore-bearing solutions.

\section{EARLY REGIONAL METAMORPHISM.}

Evidences of early regional metamorphism are found in the Eagle Mountain iron-ore district only in one small area-the area of gneiss, schist, and quartzite in the central part of the dome. The rocks in this area consisted originally of sandstone, dolomite, and biotite granite. The dolomite occurred in thin layers interbedded with the prevailing sandstone. The relation of the granite to the sediments is not known. It may have been the basement in which they were deposited or it may have been intruded into them after their deposition. These rocks were subjected to great pressure and probably also to heat, which caused the alteration of the sandstone to quartzite and schist, the dolomite to serpentinized marble, and the granite to gneiss. Schist was formed from the sandstone where it contained impurities; quartzite was formed from it where it consisted largely of pure quartz sand. The serpentinization of the dolomite was dueto original impurities in it. Where pure it was simply coarsely crystallized. The granite where even grained was altered to an ordinary banded gneiss, but where it was porphyritic its metamorphism resulted in a typical augen gneiss. The latter is the more characteristic in this area.

The source of the pressure that caused this metamorphism is unknown, but as the metamorphism is widespread its cause must have been effective over a large area.

\section{METAMORPHISM BY QUARTZ MONZONITE.}

The later sediments deposited on the old metamorphosed rocks consisted first of quartz sandstone, followed by arkosic sandstone, dolomite, and limestone, quartz sandstone, and conglomerate. Quartz monzonite was intruded into these rocks in large masses, causing the development of great pressures and high temperatures, which produced changes in them similar to changes produced in the early. metamorphism upon the older rocks. 
The lower quartz sandstone was altered to a hard, vitreous quartzite, so recrystallized that individual grains are indistinguishable. The arkosic sandstone above it was metamorphosed into sericite schist; the upper quartz sandstones were changed to dense finegrained or vitreous quartzites. The conglomerate was consolidated and firmly cemented.

The calcareous sediments suffered greater metamorphism than the siliceous sediments. They were recrystallized into marble or, locally, where impurities were present, into silicate rocks. The principal silicate rocks developed with the marble are pyroxenic marble and ophicalcite or serpentinized marble. From their occurrence it appears that the pyroxenic marble developed first and that the ophicalcite was formed later by its alteration. Both occur locally in formations which are prevailingly pure crystalline dolomite.

The pyroxenic marble consists of pure marble with layers, irregular masses, and lumps of white, granular pyroxene and has the appearance of a cherty limestone. The ophicalcite similarly consists of pure marble with layers, irregular masses, and nodules of serpentine. Frequently unaltered pyroxene occurs with it, being especially abundant as cores in serpentine nodules, as described on a preceding page. (See pp. 39, 54.)

Besides the general metamorphism of the sediments, there was marked contact metamorphism during the quartz monzonite intrusion. This was greatest in the carbonate rocks, but locally was also very marked in the quartzite and in the quartz monzonite itself.

The characteristic metamorphic minerals in the dolomite along the contact with quartz monzonite intrusions are garnet, muscovite, phlogopite, pyroxene (diopside or augite), iron oxide, and quartz. Those developed in the quartzite and quartz monzonite are epidote, hornblende, garnet, pyroxene, magnetite, titanite, and quartz.

The characteristic contact phase of the dolomite consists of crystalline dolomite, with disseminated silicates in small crystals. In places coarsely crystalline and finely crystalline dolomite occur in successive alternating bands parallel to the contact.

Metamorphic minerals occur in the dolomite for several feet from the contact. In places they consist of disseminated pyroxene, muscovite, quartz, and iron oxide, and elsewhere phlogopite is abundantly associated with these. The muscovite occurs in small flakes and generally has a slight pink or yellow pleochroism. Locally some of the muscovite is altered to colorless chlorite. The phlogopite is found in larger flakes, some of them a tenth of an inch in the longer diameter. It is not so abundant as muscovite. The pyroxene occurs in minute disseminated grains, some of them green and others brown. The quartz is in disseminated grains or segregated small 
rounded masses. Iron oxides, both magnetite and hematite, occur in disseminated specks.

Other contact phases of the dolomite consist of masses of garnet (grossularite) or of garnet mixed with pyroxene, tremolite, quartz, dolomite, magnetite and titanite. These phases occur as distinct masses along the contact of dolomite and quartz monzonite and are generally sharply defined from both. They are probably formed by the intermingling of materials from both the intruded and the intrusive rock and differ from other contact phases in containing but a small percentage of the original dolomite, whereas the other phase contains but a very small percentage of metamorphic minerals. In places the garnet masses are coarsely crystalline, being made of garnet crystals, the largest three-quarters of an inch in diameter. In places fibrous tremolite in crystals 2 inches or more long is mixed with the garnet, and large crystals of dolomite are associated with the tremolite. Where the garnet is mixed with iron oxide, pyroxene, and other metamorphic minerals it is generally more finely crystalline. Locally garnet masses are compact and exhibit no crystalline structure.

The metamorphic phases of the quartz monzonite in places extend but a few inches from the contact with the sediments; elsewhere they extend for several hundred feet. The characteristic contact phase is epidote rock, consisting in places entirely of epidote and elsewhere of epidote mixed with quartz, green hornblende, or titanite. In some places, especially near the contact with dolomite, the hornblende becomes the principal constituent and garnet locally occurs in it. At several localities where the contact of the dolomite and the quartz monzonite was examined it was found that the dolomite contained disseminated muscovite pyroxene and quartz; as described above, while the quartz monzonite immediately at the contact consisted of a dark-green layer of garnet, green hornblende, quartz, epidote, and dolomite from half an inch to an inch thick. These minerals are intermixed in irregular masses. The green hornblende is generally partly altered to chlorite. Inside of the green layer is a white layer of about the same thickness, in which all the alkali feldspar has been altered to lime-soda feldspar and in which irregular masses of green hornblende, epidote, and garnet, and veins of dolomite and epidote are developed. Quartz is present in irregular grains, as it is elsewhere in the quartz monzonite. Inside of the lime-soda feldspar layer the quartz monzonite consists largely of alkali feldspar and quartz, with some lime-soda feldspar; this being the aplitic phase of the quartz monzonite described above.

In the contact phases of the quartzite the epidote is generally less abundant than in those of the quartz monzonite, and magnetite and hornblende become more important. Locally pyroxene is an abundant constituent, and in such places hornblende is generally rare. 
All the metamorphic phases of the sediments and quartz monzonite produced by the intrusion of the latter have doubtless been affected by the ore-bearing solutions and are further discussed in that connection.

\section{METAMORPHISM BY ORE-BEARING SOLUTIONS.}

The metamorphism by ore-bearing solutions is confined mostly to the dolomite and quartzite series, though locally the upper part of the schistose arkose phase of the vitreous quartzite series is also affected. It has resulted in the replacement of much of the dolomite and a little of the quartzite and quartz monzonite by iron ore and associated metamorphic minerals. Most of the minerals formed by the earlier metamorphism are believed to have recrystallized with those introduced by the ore-bearing solutions. The mineral associätion, however, differs in different rocks - that is, the minerals associated with the iron ore and dolomite differ somewhat in association from those occurring in the altered quartzite and quartz monzonite. There is also a slight difference in the abundance of various minerals in different parts of the district. The following is a list of the minerals in their characteristic associations, the order being approximately that of relative abundance.

Minerals associated with dolomite.

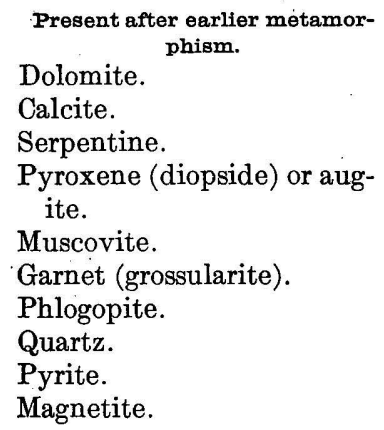

\section{Becondary.}

Hematite.

Limonite.

Chlorite.

Minerals associated with ore.

$$
\begin{array}{l|l|l}
\begin{array}{l}
\text { Introduced by ore- } \\
\text { bearing solutions. }
\end{array} & \multicolumn{1}{|c|}{\text { Secondary. }} & \text { Later. } \\
\text { Magnetite. } & \text { Hematite. } & \text { Calcite. } \\
\begin{array}{l}
\text { Pyrite. } \\
\text { Tremolite. }
\end{array} & \text { Limonite. } & \text { Dolomite. } \\
\text { Anthophyllite. } & & \text { Quartz. } \\
\text { Hornblende. } & & \\
\text { Muscovite. } & & \\
\text { Apatite. } & &
\end{array}
$$


Minerals associated with quartzite.

Present after earlier metamor-

Quartz.

Feldspar.

Biotite.

Epidote.

Hornblende.

Pyroxene.

Magnetite.
Introduced by ore-bearing solutions.

Epidote.

Muscovite.

Serpentine.

Tremolite.

Actinolite.

Magnetite.

Hornblende.

Pyroxene.

Vesuvianite.

Allanite.

Apatite.

Titanite.
Secondary.

Hematite.

Chlorite.

Sericite.

Talc.

Minerals associated with quartz monzonite.

Present after intrusion.

Feldspar.

Quartz.

Biotite.

Hornblende.

Titanite.

Apatite.

Magnetite.

Epidote.

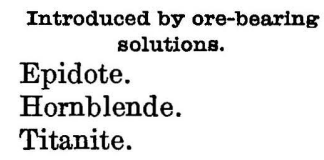
solutions.

Epidote.

Hornblende.

Titanite.

Secondary.

Sericite.

Saussurite (zoisite).

Epidote.

Chlorite.

Hematite.

Limonite.

From these lists it is seen that the principal minerals present in the sediments before ore deposition besides dolomite, calcite, and quartz were serpentine, pyroxene, mica, and garnet and that those introduced by the ore-bearing solutions were magnetite, pyrite, tremolite, epidote, and hornblende. The principal secondary mineral is hematite.

The chief minerals which now constitute the ore-bearing strata, besides the unreplaced dolomite, calcite, and quartz, are named in order of importance, hematite, magnetite, serpentine, tremolite, and muscovite. The pyroxene originally present has been entirely altered to serpentine. The pyrite introduced by the ore-bearing solutions has been altered to hematite. Epidote and hornblende are associated chiefly with contact phases of the quartz monzonite and quartzite, and only rarely occur with the ore. Garnet is for the most part associated with dolomite near local quartz monzonite intrusions and is rarely found along the principal ore horizons.

Most of the minerals occur in fairly definite association with each other, forming a series of gangue rocks of slightly different composition and with slightly different associations. The principal gangue rocks in the district besides the original dolomite and quartzite are ferruginous dolomite, serpentine-magnetite rock, tremolite-magnetite rock, mica-serpentine rock, epidote rock, and garnet rock. Most of 
these consist of the combined products of both earlier and later metamorphism.

The ferruginous dolomite is a partial replacement of pure dolomite, and also probably of limestone, by iron oxide. It is very dark in color, in places almost black, and consists of abundant irregular specks of iron oxide in a matrix of crystallized carbonates. The ironoxide specks are chiefly magnetite-and hematite, but they have thin coatings of limonite and the carbonates are iron stained around them. Some of the ferruginous dolomite contains scattered quartz grains or small aggregates of quartz crystals, but except these the rock contains but few impurities.

Ferruginous dolomite is scattered irregularly along the iron-ore belt in large and small masses, and associated with it are other phases of gangue rock, these occurring where the original dolomite contained impurities. A peculiar fact, for which no explanation has yet been found, is that in places large masses of this partly replaced dolomite occurs with little or no pure ore, whereas in other places large bodies of pure iron ore, with sharp definite contacts, occur in beds of pure crystalline dolomite.

Serpentine-magnetite rock consists of serpentine and magnetite with locally disseminated flakes of muscovite. The magnetite and serpentine are present in varying proportions. Phases of the rock consist of nearly pure serpentine; other phases consist largely of magnetite. The two may be irregularly intermixed or they may be in separate bunches or bands. In places the serpentine occurs in small round bodies surrounded by magnetite, as it occurs in ophicalcite surrounded by dolomite. The muscovite is associated with the serpentine and is generally partly altered to serpentine or chlorite. The serpentinemagnetite rock represents the replacement of ophicalcite by iron ore. The dolomite was replaced by iron oxide and the serpentine was left unaltered or was simply recrystallized and redistributed. It occurs as fibrous radial aggregates and in granular masses. The muscovite was for the most part originally associated with the serpentine. Nodules of serpentine with unaltered pyroxene were not found in any of the serpentine-magnetite rocks. The association of the serpentinemagnetite rock with the ore and the retention in it of the original ophicalcite textures is one of the best evidences of two stages of metamorphism in the iron-bearing series of sediments.

Tremolite-magnetite rock consists largely of tremolite, magnetite, and hematite. Locally anthophyllite is associated with the tremolite, being perhaps an alteration product from it. Tremolite-magnetite occurs both as an alteration product from impure dolomite and from quartzite. Where altered from the dolomite, it generally contains serpentine and an abundance of iron oxide, while in the alteration product from the quartzite iron oxide occurs only sparingly. In the 
latter phase actinolite, a little quartz, and locally green hornblende occur. Chlorite is present as an alteration product of green hornblende and actinolite. Apatite and titanite occur sparingly in both phases.

The tremolite and anthophyllite are generally present in fibrous radial masses, single fibrous sheaves an inch or two in length occurring frequently.

Tremolite-magnetite rock may occur in masses inclosed in the ore bodies, or it may occur inclosed in quartzite at some distance from the ore or quartz monzonite. Some of the silicate minerals in it may have been a product of the metamorphism due to the quartz monzonite intrusion, but most of this gangue rock was produced by the orebearing solutions. The chief evidences of this mode of origin are its occurrence in the quartzite some distance from the quartz monzonite and the fact that the tremolite rock in the quartzite is found only along certain zones, these being probably where the hot solutions penetrated. It shows no definite relation to quartz monzonite masses.

Mica-serpentine rock occurs as an alteration product of impure dolomite and quartzite. It consists largely of serpentine and muscovite with varying amounts of chlorite and iron oxide. The muscovite is present both as large flakes and in the form of granular aggregates as sericite. Some flakes of muscovite are from half an inch to threefourths of an inch in diameter, though in most of the phases they average about a tenth of an inch in diameter. Chlorite occurs as an alteration product of muscovite and is locally abundant. The serpentine is present in the granular form or as fibrous radial aggregates. The iron oxide is mostly in the form of magnetite, but hematite and some limonite are present. They occur as disseminated irregular specks.

Mica-serpentine rock occurs commonly along the contact of the quartzite with iron-ore masses, but is also found abundantly within the iron-ore bodies. From its relation to the ore bodies it appears to be largely a product of the metamorphism by ore-bearing solutions, though it undoubtedly also contains recrystallized minerals of the earlier metamorphism.

Epidote rock is found as a metamorphic product of quartzite and quartz monzonite. It consists largely of epidote, with which is generally associated green hornblende, magnetite, quartz, calcite, titanite, pyrite, pyroxene, or allanite, or two or more of these minerals. The matrix of the rock generally consists of epidote in which the other is embedded. Of these the most common are green hornblende, quartz, and magnetite, the first two being abundant in epidote rock altered from quartz monzonite, and all three being abundant in epidote rock altered from quartzite. Magnetite is rare in epidote rock altered from 
quartz monzonite, but in that altered from quartzite it may compose one-half or more of the mass. Pyroxene and allanite occur only in the epidote rock altered from quartzite.

Garnet rock occurs as an alteration product of dolomite and is commonly found at or near the contact of quartz monzonite. Most of the garnet masses consist of pure grossularite, but some contain other minerals, such as tremolite, pyroxene, magnetite, amphibole, quartz, and titanite.

The epidote and garnet rocks are largely products of the metamorphism by the quartz monzonite in connection with which they have already been described. In many places, however, they have been recrystallized by and have received additions from the ore-bearing solutions. Locally epidote rock is found along the contact of some of the later dikes and here it apparently owes its origin to them. 



\section{INDEX.}

A.

Acknowledgments to those aiding.......... 10

Amboy Basin, basalt flows in ............ 19-20

Andesite porphyry, gray dikes of.......... 51-52

in green dikes, petrography of. ......... 53

Aplite dikes, distribution and petrographic character of...............49-50

Arizona, western part of, rocks of........... 17

\section{B.}

Barnes, L. S., assistance rendered by ........ Basalt flows, character and distribution of. . 54-55 Beegum, Cal., deposits, character and extent of.....................

Bibliography of Pacific coast iron ores...... Black Diamond No. 1 claim, iron-ore deposits on, plate showing.

structure of ore and rocks of, map and sections showing............

Black Diamond No. 8 claim, structure of ore and rocks of, map and sections showing..................

Black Diamond No. 45 claim, structure of ore and rocks of, map and sections showing.

Boulder well, location and water supply of. Brooklyn mine, water supply at............ Brown, C. E., assistance rendered by....... Brown, W. W., assistance rendered by...... Buzzard Spring, location of ................

C.

Calcite, pure, analysis of.

Chocolate Mountains, rocks of. .

Chuckwalla Mountains, rocks of .

Clealum, Wash., iron ores, character and extent of........................

Climate, general features of.................

Colorado Desert, rocks of. . .................. 16-21

rocks of, section showing..............

Cottonwood Mountains, rocks of ............

Cottonwood Springs, location and water supply of . . . . . . . . . 14-15

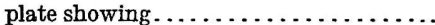

Coxcomb Mountains, northern part of, plate showing..................

rocks of ..............................

D.

Dale, mountains near, rocks of............ 20

mountains near, plate showing........... 12

Deposits, general succession of.............. 19-21

types of ..................... 61-63

See also Ore deposits.

Desert areas, topographic features of......... Development of Eagle Mountain ores, status of...................68 $68-69$
Page.

Dickman, R. N., assistance rendered by..... 10,65 Dikes and sheets, character and distribution

of . . . . . . . . . . . . relations of, to major intrusions........ 55

Dolomite, analyses of .................. . 38 minerals associated with.............. 73 with iron ore, plate showing........... 58

Dolomite and quartzite series, distribution and character of ............... 35-41

Drainage, general features of ................ 12-14

E.

Eagle Mountain deposits, general character of. $\quad 8$ Eagle Mountain district, distribution of ore deposits in, plate showing. In pocket. general geology of ................... 22-27 general section of rocks of, figure showing. 21 geologic and topographic map of .. In pocket.

Eagle Mountain dome, geologic sketch map of. 23

Eagle Mountains, character and geographic relations of. ................ 11-12

climate, vegetation, and topography of.. 12-14 general sections of rocks in........... 24

figure showing................... 21

iron ores of, analyses of ................ 65

commercial value of .................. 68-69

location of............................ 10-12

index map showing................ 11

rocks of............................ 20

Eagle Tank, location and water supply of..... 15-16

East End camp, routes to................ 10

East End group of deposits, structure of ore and rocks in, map and section showing................. In pocket.

Epidotic phase of quartz monzonite, discussion of...................... 47-48

F.

Feldspathic phase of quartz monzonite, discussion of .....................

Fluviatile deposits, character and derivation of .......................... 41

Formations, general succession of, and sections indicating.................. 22-25

12 Fuel, effect of absence of, on development of iron-ore deposits............... 69

Furnaces on Pacific coast, location and activity of.

G.

Geography, general features of ............. 10-16 Geology, general sketch of .................. 16-27 historical outline of .................. 27 of Eagle Mountain district, map showing.. In pocket. 
Page.
$\begin{gathered}\text { Gneiss, distribution and structure of.......... } \\ \text { petrographic character of.................. }\end{gathered}$
$\begin{gathered}27-28 \\ \text { Gray dikes, distribution and petrographic }\end{gathered}$
$\begin{gathered}\text { character of..................... } \\ \text { Gray Eagle group, development at.......... }\end{gathered}$
Green dikes and sheets, distribution and character of

\section{H.}

Historical geology, account of:.............. Holland, W. L., assistance rendered by......

I.

Igneous rocks, distribution and character of. . 42-55 Investigations, scope of 9-10,19-21

Inyo County, rocks of. 17-18

Iron, amount of, in Eagle Mountain ores, figures showing...................

Iron Chief mine, development at............

plate showing.

routes to.

view from

Iron No. 1 claim iron-ore deposits on plat showing

Iron No. 2 claim, iron-ore deposits on, plate showing

Iron No. 4 mine, section of vitreous quartzite at.

Iron No. 5 elaim, iron-ore deposits on, plate showing.

Iron No. 8 mine, section of vitreous quartzite at. ............................

Iron No. 26 claim, iron-ore deposits on, plate showing.

structure of ore and rocks of, map and sections showing.

Iron No. 27 claim, iron-ore deposits on, plates showing.

structure of ore and rocks of, map and sections showing.

Iron No. 30 claim, iron-ore deposits on, plate showing.

structure of ore and rocks of, map and sections showing................

Iron ore and contact rock, distribution of, plate showing...................

deposits of, geologic relations of.......... 25-26

distribution and character of..............

with crystalline dolomite, plate showing. .

Iron-ore belt, plate showing

$$
\text { K. }
$$

Katie Gray claim, iron-ore deposits on, plate showing ........................

L.

Leith, C. K., work of, in Utah.

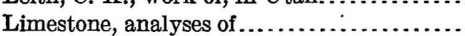

Literature of Pacific coast iron ores.

M.

Maria Mountains, rocks of.................

Metamorphism, character, extent, and methods of

effect of ore-bearing solutions in......... $73-77$

effect of quartz monzonite in............. $70-73$

periods of........................... 69-70

regional, effect of .

Microdiorite, petrography of.

Page.

Minaret, Cal., deposits, character and extent

of ......................... 8

Mohave Desert, southeastern part of, rocks of.. 16-21 southeastern part of, section of, rocks in... 19

\section{O.}

Ore, analyses of......................... 65 character and grade of ................ 63-66 estimate of quantity of ............... $66-68$ minerals associated with............... 73 See also Ore deposits.

Ore-bearing solutions, metamorphism by .... 73-77

Ore deposits, distribution of............... $55-59$

extent of, and routes to ............... 10

geologic relations and structure of....... 59-61

location of ............................ 8

nature of ............................61-63

ores of, character and grade of . . . . . . . 63-66

estimate of quantity of............ 66-68

present development of............... 68-69

Ore formation, processes of.............. 69-77

Orocopia Mountains, rocks of.............. 21

58

33

58

33

58

56

56

58

56

56

26

58

58

Roads, location of .

and charactor of

Rodger No. 1 claim, iron-ore deposits on plate showing...................

Rodger No. 2 claim, iron-ore deposits on, plate showing..................

7-8

8-9

20

See Vitreous quartzite; Dolomite and quartzite series.

Quartz monzonite, intrusions of, distribution and structure of ............... 42-44

intrusions of, epidotic phase of........... 48

feldspathic phase of................ 47-48

petrography of..................... 44-47

metamorphism produced by........... 70-73

minerals associated with................ 74

\section{R.}

Railroads of Eagle Mountain district, location of........................ 10

Randsburg district, rocks of ................ 18

Red Ribbon Spring, location of............ 16

Regional metamorphism, effects of........... 70

9

10 
Rodger No. 4 claim, iron-ore deposits on, plate showing.................

Rodger No. 5 claim, iron-ore deposits on, plate showing..................

Rodger No. 8 claim, iron-ore deposits on, plate showing..................

Rodger No. 9 claim, iron-ore deposits on, plate showing.

S.

San Bernardino County, rocks of

San Bernardino Mountains, rocks of .

$17-18$

Scapolite-pyroxene rock, petrography of..... 53-54

Schist, character and distribution of ........ 29-30

Sedimentary rocks, character and distribution of........................ 30-41

Sheephole Mountains, rocks of.

$30-41$

Soda syenite porphyry, petrography of...... 52-53

Solutions, carrying ores, metamorphism by.. 73-77

Stage roads, service on .................... 10

Structure, general features of ............. 22-25
T.

Page.

Topography, general features of............ 12-1.4 of Eagle Mountain district, map showing..................... In pocket.

Trails, and roads, location and character of.. 10

v.

Vegetation, general character of............ 14

Virginia claim, iron-ore deposits on, plate showing..................... 58

Vitreous quartzite series, character and distribution of................... 30-35

schistose phase of, sections showing...... 33

W.

Watering places, locations of................ 14-16

Wherry, H. P., assistance rendered by....... 10,65

Wizard claim, iron-ore deposits on, plate showing...................... 58

Work in Eagle Mountain district, scope of... 9-10 in Mohave and Colorado deserts, extent of .......................... 16-21

$19557^{\circ}-$ Bull. $503-12-6$ 









MAP AND SECTIONS SHOWING THE DISTRIBUTION AND STRUCTURE OF IRON ORE AND ASSOCIATED ROCKS IN THE EAST END GROUP OF ORE DEPOSITS 
